

\section{DISCLAIMER}

This report was prepared as an account of work sponsored by an agency of the United States Government. Neither the United States Government nor any agency Thereof, nor any of their employees, makes any warranty, express or implied, or assumes any legal liability or responsibility for the accuracy, completeness, or usefulness of any information, apparatus, product, or process disclosed, or represents that its use would not infringe privately owned rights. Reference herein to any specific commercial product, process, or service by trade name, trademark, manufacturer, or otherwise does not necessarily constitute or imply its endorsement, recommendation, or favoring by the United States Government or any agency thereof. The views and opinions of authors expressed herein do not necessarily state or reflect those of the United States Government or any agency thereof. 


\section{DISCLAIMER}

Portions of this document may be illegible in electronic image products. Images are produced from the best available original document. 


\section{DISCLAIMER}

This report was prepared as an account of work sponsored by an agency of the United States Government. Neither the United States Government nor any agency thereof, nor any of their employees, makes any warranty, express or implied, or assumes any legal liability or responsibility for the accuracy, completeness, or usefulness of any information, apparatus, product or process disclosed, or represents that its use would not infringe privately owned rights. Reference herein to any specific commercial product, process or service by trade name, trademark, manufacturer, or otherwise, does not necessarily constitute or imply its endorsement, recommendation, or favoring by the United States Government or any agency thereof. The views and opinions of authors expressed herein do not necessarily state or reflect those of the United States Government or any agency thereof. 


\title{
ADVANCED GAS COOLED NUCLEAR REACTOR MATERIALS EVALUATION AND DEVELOPMENT PROGRAM
}

\author{
PROGRESS REPORT \\ FOR PERIOD
}

April 1, 1980 - June 30, 1980

BY

PROJECT STAFF

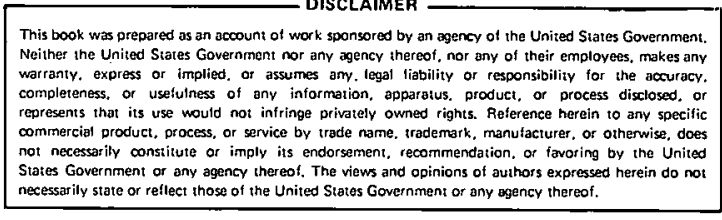

\section{GENERAL ELECTRIC COMPANY ENERGY SYSTEMS PROGRAMS DEPARTMENT SCHENECTADY, NEW YORK 12345 \\ GENERAL ELECTRIC}

November 14, 1980

\author{
Prepared for \\ THE U. S. DEPARTMENT OF ENERGY \\ Under Contract No. DE-AC-02-76ET34202
}


Foreword

v

Abstract

vi

Other Reports in this Series

vii

1.0 Introduction

$1-1$

2.0 Program Status

2.1 Task 1 - Selection of Candidate Alloys

2-1

2.2 Task 2 - Materials Procurement and Characterization

$2-1$

2.3 Task 3 - Testing and Analysis Facilities and Equipment

$2 \div 8$

2.4 Task 4 - Simulated Reactor Helium Environment

$2-13$

2.5 Task 5 - Mechanical Properties Evaluation

$2-17$

2.6 Tasks 6 and 7 - Thermal Stability Evaluation and Primary

$2-32$

2.7 Task 9 - Data Management and Program Management

3.0 Work to be Completed during the Next Quarter 
Table No.
Alloys Selected for Intensive Screening Tests and Their Nominal Compositions

Alloy Composition of Direct Cycle Helium Turbine Alloys for Intensive Screening Testing

MA-956 Creep-Rupture Characterization Test Results

MA-956 Room Temperature Tensile Test Results

Parameters Employed in the Fabrication of Weldments for Phase 2 Testing

Loop No. 1 Gas Chemistry History April 1, 1980 to June $30,1.980$

Average Gas Chemistry Change, By Retort, April to June, 1980

Screening (Multispecimen) Creep Results for the Nuclear Process Heat Alloys

Screening (Multispecimen) Creep Results for the Direct Cycle Helium Turbine Alloys

Phase 2 Intensive Screening Nuclear Process Heat Alloy Air Creep-Rupture Tests

Weight Change Results of Specimens Aged in Controlled Purity Helium

Results from Visual Examination of Structural Stability Specimens After Exposure to $750^{\circ} \mathrm{C}$ Controlled Purity Helium

Results from Visual Examination of Screening Creep Specimens After Exposure to $750^{\circ} \mathrm{C}$ Controlled Purity Helium

Results from Visual Examination of Screening Creep Specimens After Removal from $850^{\circ} \mathrm{C}$ Controlled Purity Helium Exposure

Results from Visual Examination of Screening Creep Specimens after Removal from $950^{\circ} \mathrm{C}$ Controlled Purity Helium Exposure

Summary of Surface Corrosion Measurements and Internal Microstructural Analysis for Alloys Aged Unstressed in Controlled Purity Helium for 3,000 Hours

Page 
Table No.

Page

Summary of Corrosion Measurements for Selected Alloys Aged Unstressed in Controlled Purity Helium

\section{LIST OF FIGURES}

Figure No.

Page

1

Geometry of Wrought Plate Butt Weldments

Fracture Surfaces of Uncoated Inconel 617

$2-29$ Charpy Impact Specimens

Fracture Surfaces of Coated Inconel 617 Charpy Impact Specimens

Weight Change of Wrought Iron-Base Alloys Aged Unstressed at $750^{\circ} \mathrm{C}$ in Controlled Purity Helium

Weight Change of Wrought Nickel Base Alloys Aged Unstressed at $750^{\circ} \mathrm{C}$ in Controlled Purity Helium

Weight Change of Centrifugally Cast Alloys Aged Unstressed at $750^{\circ} \mathrm{C}$ in Controlled Purity Helium

Weight Change of Oxide Dispersion Strengthened Alloys Aged Unstressed at $750^{\circ} \mathrm{C}$ in Controlled Purity Helium Aged Unstressed in Controlled Purity Helium

3,000-Hour Weight Change Results for Selected - Centrifugally Cast Alloys Aged Unstressed in Controlled Purity Helium.

Optical Photomicrographs Showing Etched Internal Microstructure of Inconel 617 After 3,000-Hour Exposure in Controlled-Purity Helium at $750^{\circ} \mathrm{C}$ 3,000-Hour Exposure in Controlled-Purity Helium at $750^{\circ} \mathrm{C}$ 

Hour Exposure in Controlled-Purity Helium at $750^{\circ} \mathrm{C}$

Optical Photomicrographs Showing Surface Condition and Etched Subsurface Microstructure of Inconel 618E After 3,000-Hour Exposure in ControlledPurity Helium at $750^{\circ} \mathrm{C}$ Microstructure of HK-40 After 3,000-Hour Exposure in Controlled-Purity Helium at $750^{\circ} \mathrm{C}$ and Etched Subsurface Microstructure of HK-40 after 3,000-Hour Exposure in Controlled-Purity Helium at $750^{\circ} \mathrm{C}$

Optical Photomicrographs Showing Etched Internal Microstructure of Manaurite 36XS after 3,000Hour Exposure in Controlled-Purity Helium at $750^{\circ} \mathrm{C}$ and Etched Subsurface Microstructure of Manaurite 36XS After 3,000-Hour Exposure in Controlled-Purity Helium at $750^{\circ} \mathrm{C}$

Optical Photomicrographs Showing Etched Internal Microstructure of Manaurite 900 After 3,000-Hour Exposure in Controlled-Purity Helium at. $7 \mathrm{SO}^{\circ} \mathrm{C}$

Optical Photomicrograph Showing Surface Condition of Manaurite 900 After 3,000-Hour Exposure in Controlled-Purity Helium at $750^{\circ} \mathrm{C}$

Optical Photomicrographs Showing Etched Internal Microstructure of Mo-Re 2 After 3,000-Hour Exposure in Controlled-Purity Helium At $750^{\circ} \mathrm{C}$ Condition of Mo-Re 2 After 3,000-Hour Exposure in Controlled-Purity Helium at $750^{\circ} \mathrm{C}$ 
FOREWORD

The Advanced Gas Cooled Nuclear Reactor Materials Evaluation and Development Program is being conducted for the Nuclear Power Development Division, U.S. Department of Energy, by the Energy Systems Programs Department, General Electric Company, Schenectady, New York 12345 under Contract DE-AC02-76ET34202. The Program is under the direction of Mr. J.E. Fox, DOE Program Manager, and is being managed for the General Electric Company by Mr. R.G. Frank, Manager, Materials Technology. The Principal. Investigator, with responsibility for overall technical coordination of the Program is Dr. O.F. Kimbal1, Manager, Gas Reactor Materials, assisted by Dr. J.F. Stubbins, Materials Engineer, Gas Reactor Materials. Major contributors to the Program are:

High Temperature Reactor Materials Testing Laboratory

Dr. D.H. Baldwin, Large Steam Turbine-Generator Division, Laboratory Lead Engineer

Mr. K. McIver, Large Steam Turbine-Generator Division, Principal Engineer - Fatigue Testing

Mr. R.K. Elton, Large Steam Turbine-Generator Division, Gas Chemist

Mr. A. Anderson, Large Steam Turbine-Generator Division, Project Manager

Materials for Nuclear Process Heat Systems

Messrs. S.Z. Hayden and R.A. Ellis, Large Steam TurbineGenerator Division - Principal Investigators

Dr. S. Yukawa, Large Steam Turbine-Generator Division, Project Manager

Materials for Direct Cycle Helium Turbine Systems

Dr. J.F. Stubbins, Energy Systems Programs Department, Principal Investigator and Project Manager

Mr. E.W. Ross, Aircraft Engine Business Group, Consulting Engineer

Basic Gas/Metal Corrosion Effects

Dr. D.W. McKee, Corporate Research and Development Center, Principal Investigator

Dr. A.W. Urquhart, Corporate Research and Development Center, Project Manager

Data Management

Dr. R.B. Hand, Aircraft Engine Business Group, Principal Engineer 
This report presents the results of work performed from April 1, 1980 through June 30, 1980 on the Advanced Gas-Cooled Nuclear Reactor Materials Evaluation and Development Program. The objectives of this program are to evaluate candidate alloys for Very High Temperature Reactor (VHTR) Nuclear Process Heat (NPH) and Direct Cycle Helium Turbine (DCHT) applications, in terms of the effect of simulated reactor primary coolant (helium containing small amounts of various other gases), high temperatures, and long time exposures, on the mechanical properties and structural and surface stability of selected candidate alloys. A second objective is to select and recommend materials for future test facilities and more extensive qualification programs.

Work covered in this report includes the activities associated with the status of the simulated reactor helium supply system, testing equipment and gas chemistry analysis instrumentation and equipment. The progress in the screening test program is described; this includes: screening creep results and metallographic analysis for materials. thermally exposed or tested at 750,850 and $950^{\circ} \mathrm{C}\left(1382,1.562\right.$ and $\left.1742^{\circ} \mathrm{F}\right)$. The intitiation of air creep-rupture testing in the intensive screening test program is discussed. In addition, the status of the data management system is described. 


\section{OTHER REPORTS IN THIS SERIES}

\section{QUARTERLY PROGRESS REPORTS}

September 23, 1976 to December 31, 1976

$$
\begin{aligned}
& \mathrm{C} 00-2975-3 \\
& \mathrm{C} 00-2975-10 \\
& \mathrm{C} 00-2975-13 \\
& \mathrm{C} 00-2975-17 \\
& \mathrm{C} 00-2975-20 \\
& \mathrm{C} 00-2975-21 \\
& \mathrm{C} 00-2975-22 \\
& \mathrm{C} 00-2975-25 \\
& \mathrm{C} 00-2975-28 \\
& \mathrm{C} 00-2975-31 \\
& \mathrm{C} 00-2975-34 \\
& \mathrm{C} 00-2975-37 \\
& \mathrm{C} 00-2975-40 \\
& \mathrm{C} 00-2975-43
\end{aligned}
$$$$
\text { January 1, } 1977 \text { to March 31, } 1977
$$$$
\text { April 1, } 1977 \text { to June 30, } 1977
$$$$
\text { July 1, } 1977 \text { to September 30, } 1977
$$$$
\text { October 1, } 1977 \text { to December 31, } 1977
$$$$
\text { January 1, } 1978 \text { to March 31, } 1978
$$$$
\text { April 1, } 1978 \text { to June 30, } 1978
$$$$
\text { July 1, } 1978 \text { to September 30, } 1978
$$

October 1, 1978 to December 31, 1978

January 1, 1979 to March 31, 1979

April 1, 1979 to June 30, 1979

July 1, 1979 to September 30, 1979

October 1, 1979 to December 31, 1979

January 1, 1980 to March 31, 1980

\section{TOPICAL REPORTS}

1. Selection of Candidate Alloys

Volume 1 - Advanced Gas Cooled Reactor Systems Definition by M. Marvin

Volume 2 - Selection of Alloys for Screening Creep and Structural Stability Studies by R.M. Goldhoff, R.V. Hillery, and $S$. Yụkawa

Volume 3 - Selection of Surface Coating/ Substrate Systems for Creep and Structural Stability Studies
C00-2975-16

October 31,1978

December 31,1978

June 20, 1980 
Section 1.0

INTRODUCTION 


\subsection{INTRODUCTION}

The Very High Temperature Reactor (VHTR) Nuclear Process Heat (NPH) and Direct Cycle Helium Turbine (DCHT) Systems are being developed to provide an expanded energy capability and to facilitate conservation of or substitution for scarce energy resources. In both cases, the use of high temperature helium-cooled reactors will require a knowledge of the long term properties of reactor primary coolant containment materials and of the materials used in constructing related hardware. Because of the very high temperatures required for NPH and DCHT applications, the need is evident for materials testing in the proper helium environment in the temperature range from $750^{\circ}-1050^{\circ} \mathrm{C}\left(1382^{\circ}-1922^{\circ} \mathrm{F}\right)$ on those alloys which might serve as materials of construction for heat exchangers, ducting, turbine blades and vanes and other high temperature structural components.

The objectives of the Advanced Gas Cooled Nuclear Reactor Materials Evaluation and Development Program are to:

1. Evaluate candidate alloys for Very High Temperature Reactor (VHTR) Nuclear Process Heat (NPH) and Direct Cycle Helium Turbine (DCHT) applications, in terms of the effect of the primary coolant and thermal exposure on:

- Surface stability ("corrosion" resistance) in 10,000 hours.

- Structural stability in 10,000 hours - changes in microstructure and tensile, impact and fatigue properties.

- Creep - rupture properties in 15,000 hours.

- Fatigue properties

Low Cycle $10^{3}$ to $10^{5}$ cycle High Cycle $10^{5}$ to $10^{7}$ cycle

2. Select and recommend materials for future test facilities and more extensive qualification programs. 
The data base will permit the selection of materials of construction and should provide a reliable level of design data for the construction of various items of development hardware leading to the successful development of NPH and DCHT systems. The present lack of an accurate measure of materials capabilities under these high temperature helium environments is a factor which is limiting the development of the NPH and DCHT systems. This program is intended to provide such initial information. 
Section 2.0

PROGRAM STATUS 
The Advanced Gas Cooled Reactor Materials Evaluation and Development' Program is organized into nine (9) tasks which are designed to accomplish the program objectives 1isted in Section 1.0 of this report. The task structure (Program Work Breakdown Structure) and a brlef description of each task (Program Work Statement) have been included in the first Quarterly Report covering the period September 23, 1976 - December 31, 1976, report number C00-2975-3.

\subsection{TASK 1 - SELECTION OF CANDIDATE ALLOYS}

The selection of alloys for the screening phase of the program has been completed. A list of the alloys selected for the program was presented in topical report number C00-2975-16, Volume 2, dated December 31, 1978 and entitled: Selection of Alloys for Screening Creep and Structural Stability Studies. The. selection of alloys for the Intensive Screening Phase of the program was completed in November 1979 and approved by DOE in January 1980. The alloys and their nominal compositions are listed in Table $i$.

\subsection{TASK 2 - MATERIALS PROCUREMENT AND CHARACTERIZATION}

\subsubsection{Direct Cycle Helium Turbine (DCHT) Alloys}

\subsubsection{Materials Procurement}

The procurement of all DCHT material for the Phase 1 screening test program was completed by June 1978 .

The alloys for the Phase 2 intensive screening test program were procured during the present quarter. All of these alloys have been received or were being shipped by end of the quarter. The material includes MA-754, Rene' 100 and Alloy 713LC.

Due to a misunderstanding by the vendor, cast-to-size specimens were poured from Alloy $713 \mathrm{C}$ rather than Alloy 713LC, as intended. The vendor was required to recast test specimens with Alloy 713LC. The main difference between Alloy 713C and Alloy $713 \mathrm{LC}$ is lower $C$ in the LC version; $0.13 \mathrm{wt}$ \% C nominal vs $0.06 \mathrm{wt} . \%$ $\mathrm{C}$ nominal. The heat of Alloy $713 \mathrm{C}$ shipped by the vendor has $0.10 \mathrm{wt}$. \% C. Table 2 shows the chemical composition (vendor analyses) of the heats presently used in the 


\section{TABLE I}

ALLOYS SELECTED FOR INTENSIVE SCREENING TESTS AND THEIR NOMINAL COMPOSITIONS

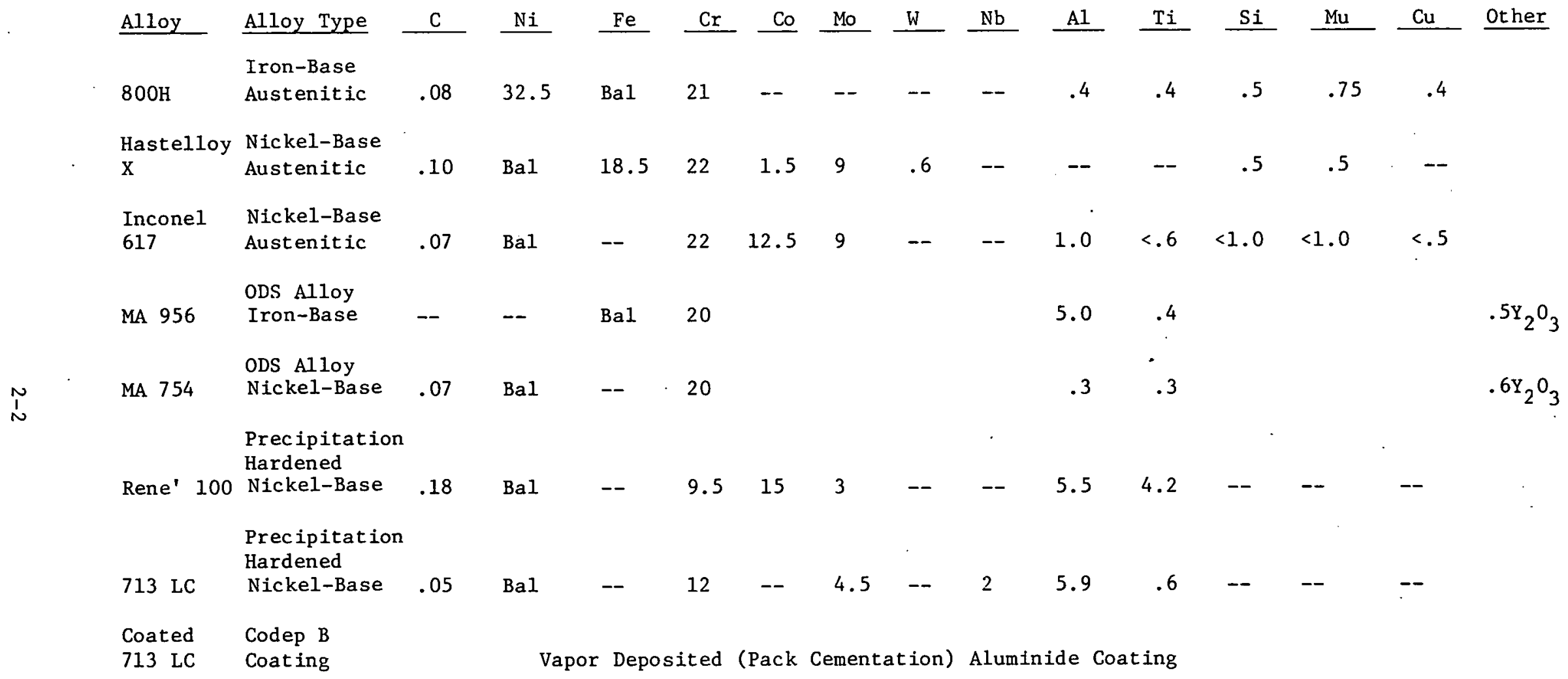


ALLOY COMPOSITION OF DIRECT CYCLE HELIUM TURBINE ALLOYS FOR INTENSIVE SCEEENING TESTING

VENDOR CHEMISTRY CERTIFICATION (W/0):

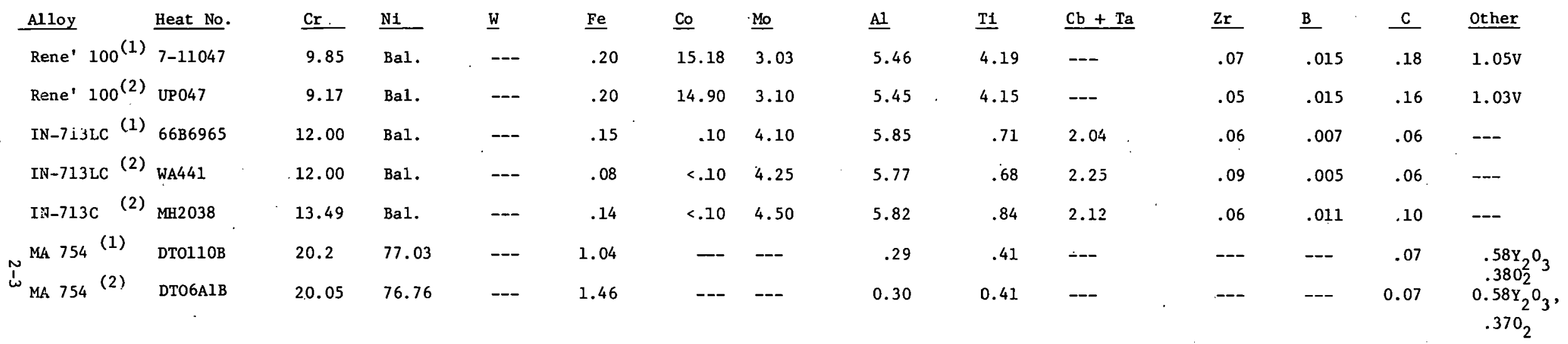

(1) Material for Screening Phase

(2) Material for Intensive Screening Phase 
screening program and the compositions of the heats in the intensive screening program for Rene' 100, Alloy 713, MA754.

The lower carbon version, Alloy 713LC, was developed to solve casting problems encountered, with Alloy 713C. In small sections, the castability is very similar, but in larger sections some segregation problems occur with Alloy $713 \mathrm{C}$, and it is less castable than Alloy 713LC. For test specimen sizes used in this program, castability is not a concern. Due to this, it was decided to use the Alloy $713 \mathrm{C}$ for coated specimens, and run some uncoated Alloy $713 \mathrm{C}$ in paral1el for comparison purposes in addition to testing uncoated Alloy 713LC.

\subsubsection{Materials Characterization}

This subtask was completed for the Phase I screening test program and the final results reported in the Progress Report for July 1, 1978 to September 30, 1978, report number C00-2975-25.

Additional characterization alr creep-rupture tests will be run on the heats of MA-754, Alloy 713LC, Alloy 713C and Rene' 100 procured for the intensive screening test program. Stress levels, selected for 300 hours to rupture, will be used for these tests. The results will allow proper selection of stress for longer term creep-rupture tests in both controlled purity He and in air.

\section{$\underline{2.2 .2 \text { Nuclear Process Heat (NPH) Alloys }}$}

\subsubsection{Materials Procurement}

The procurement of all NPH materials, sufficient for both testing phases, was completed by September 1978 .

\subsubsection{Materials Characterization}

The materials acceptance and characterization testing was completed in the quarter ending in December 1978.

Three 300 hour creep-rupture tests on MA-956 are currently in progress. These tests are designed to characterize the creep-rupture properties of a second heat (Heat No. ZDCR) of MA-956. This material was used in the manufacture of the MA-956 intensive phase specimens. Creep-rupture results for Heat No. ZDCR are tabulated in Table 3, along with the results obtained from the heat of MA-956 used in the screening phase. Analysis of the data obtained to date suggests that the heats appear to be fairly comparable in terms of rupture strength. The two ZDCR specimens which have ruptured failed in or very near the radius between the gage length and 
TABLE 3

MA-956 CREEP-RUPTURE CHARACTERIZATION TEST RESULTS

\begin{tabular}{|c|c|c|c|c|c|c|c|c|c|}
\hline $\begin{array}{l}\text { Heat } \\
\text { No. }\end{array}$ & $\begin{array}{l}\text { Specimen } \\
\text { No. } \\
\end{array}$ & $\begin{array}{l}\text { Test } \\
\text { Temp. } \\
\left({ }^{\mathrm{O}} \mathrm{C}\right)\end{array}$ & $\left({ }^{\circ} \mathrm{F}\right)$ & $\begin{array}{l}\text { Test } \\
\text { Stre } \\
\text { MPa } \\
\end{array}$ & (ksi) & $\begin{array}{l}\text { Time to } \\
1 \% \text { Total } \\
\text { Strain } \\
\text { (hours) } \\
\end{array}$ & $\begin{array}{l}\text { Rupture } \\
\text { Life } \\
\text { (hours) }\end{array}$ & $\begin{array}{l}\text { E1. } \\
(\%) \\
\end{array}$ & $\begin{array}{l}\mathrm{RA} \\
(\%) \\
\end{array}$ \\
\hline LCWZ & 1D00CR02 & 850 & $(1562)$ & 79 & $(11.5)$ & $\sim 1000$ & 1168.6 & 4.4 & 16.3 \\
\hline ZDCR & 1D10CR18 & 850 & (1562) & 79 & $(11.5)$ & & $623.2 *$ & 0.13 & \\
\hline LCWZ & 1D00CR03 & 950 & (1742) & 69 & $(10.0)$ & 130 & 1254.6 & 4.5 & 1.8 \\
\hline LCWZ & 1DOOCRO4 & 950 & (1742) & 69 & $(10.0)$ & --- & 20.0 & 2.3 & 3.2 \\
\hline ZDCR & 1D1OCR19 & 950 & (1742) & 69 & $(10.0)$ & --- & 183.3 & --- & --- \\
\hline LCWZ & 1D00CR05 & 1050 & (1922) & 69 & $(10.0)$ & --- & 37.5 & 2.1 & 1.2 \\
\hline 2DCR & $1 \mathrm{D} 10 \mathrm{CR} 20$ & 1050 & (1922) & 69 & $(10.0)$ & --- & 448.2 & -0.07 & 8.3 \\
\hline
\end{tabular}

* In Test 
the shoulder, This is consistent with the behavior of the original heat of material employed and implies a notch sensitivity.

An as-received MA-956. (Heat No. ZDCR) RT tensile test was run during the quarter. The results are compared in Table 4 with the tensile properties obtained from the original heat of MA-956 (Heat No. LCWZ), and vendor results from similarly heat treated sheet stock. Heat No. LCWZ is the heat being used for Phase 1 of the test program. Note that no tensile specification exists at the present time for MA-956.

Inspection of the data reveal that the strengths of the two heats are fairly comparable; however, the ductility of Heat No. ZDCR appears reduced somewhat relative to Heat No. LCWZ. There are no obvious explanations for this ductility difference at the present time, and the dissimilarity may, in fact, be due to the inherent scatter between the various heats of material. An additional feature which is readily apparent upon inspection of the data is that the bar product has about a 10 to $15 \%$ increase in tensile strength relative to the sheet product, with comparable ductility.

\subsubsection{Materials Joining Studies}

The final results for Varestraint tests were covered in the quarterly report for the period October 1, 1978 to December 31, 1978, report number C00-2975-28.

Three weldments will be included in the intensive screening phase: Alloy $800 \mathrm{H}$ - Alloy 800H, Inconel 617 - Inconel 617, and Hastelloy X - Hastelloy X. Welds will be evaluated by guided bend testing of transverse side bend specimens at room temperature after 1000-hour and 10,000-hour exposures at $750^{\circ}, 850^{\circ}, 950^{\circ}$, and

$1050^{\circ} \mathrm{C}$. This test is widely used to determine the ductility and soundness of welds in both ferrous and non-ferrous products (see ASTM E190-64, Standard Method for Guided Bend Test for Ductility of Welds).

The three weldments were prepared by using current commercial "best practice" techniques in order to simulate state-of-the-art industrially-employed procedures and standards in a laboratory environment. For each of the three alloys, gas tungsten arc (GTA) welding was employed. Filler metals included Inconel filler metal 82 for the Alloy $800 \mathrm{H}$ weldment, Inconel 617 filler metal for the Inconel 617 weldment, and Hastelloy X filler metal for the Hastelloy X weldment. Filler wires were $2.4 \mathrm{~mm}(0.093 \mathrm{in.})$ diameter $\times 91.4 \mathrm{~cm}(36.0 \mathrm{in}$,$) long in each case.$ 


\section{TABLE 4}

MA-956 ROOM TEMPERATURE TENSILE TEST RESULTS

\begin{tabular}{|c|c|c|c|c|c|c|}
\hline \multirow[b]{2}{*}{ Heat No. } & \multicolumn{2}{|c|}{$\begin{array}{l}\text { Ultimate } \\
\text { Tensile } \\
\text { Strength }\end{array}$} & \multicolumn{2}{|c|}{$\begin{array}{l}0.2 \% \text { Offset } \\
\text { Yield } \\
\text { Strength }\end{array}$} & \multirow{2}{*}{$\begin{array}{l}\text { Elong: } \\
(\%)\end{array}$} & \multirow[b]{2}{*}{$\begin{array}{l}\mathrm{RA} \\
(\%) \\
\end{array}$} \\
\hline & $\underline{\text { MPa }}$ & (ksi) & $\underline{\mathrm{MPa}}$ & (ksi) & & \\
\hline $\begin{array}{l}\text { LCWZ } \\
\text { (Bar) }\end{array}$ & $\begin{array}{l}796 \\
800\end{array}$ & $\begin{array}{l}(115.5) \\
(116.0)\end{array}$ & $\begin{array}{l}786 \\
786\end{array}$ & $\begin{array}{l}(114.0) \\
(114.0)\end{array}$ & $\begin{array}{l}13.0 \\
12.0\end{array}$ & $\begin{array}{l}41.6 \\
39.1\end{array}$ \\
\hline $\begin{array}{l}\text { ZDCR } \\
\text { (Bar) }\end{array}$ & 792 & $(115.0)$ & 757 & $(109.8)$ & 10.0 & 27.9 \\
\hline $\begin{array}{l}\text { Vendor } \\
\text { Data } \\
\text { (Sheet) }\end{array}$ & 720 & (104.4) & 635 & $(92.1)$ & 13.0 & $\therefore$ \\
\hline
\end{tabular}


The geometry which was selected for the wrought plate butt weldments is shown in Figure 1. Prior to welding, the specimens were clamped to a full-restraint metallic backing plate. Commercial grade argon was used as the shielding gas for the GTA welding, with the flow rate maintained at $0.12-0.161$ iters/sec $(15-20 \mathrm{CFH})$. A $2 \%$ thorium tungsten electrode $(2.4 \mathrm{~mm}(0.093 \mathrm{in.}) \mathrm{d} 1 \mathrm{a})$ was employed with direct current, straight polarity. Welds were wire brush cleaned and visually inspected after every pass to insure a defect-free product. The specific welding parameters (number of passes, current, and voltage) employed in the fabrication of the butt welds are presented in Table 5. After welding, the Inconel 617 weldment was judged to exhibit excessive joint distortion. This plate was, therefore, sawed through the weld, the opposite edges of the plate were machined to the appropriate weld prep configuration, and the weld was redone with much improved results.

Ten side bend specimens were machined from each alloy; eight samples will be bend tested at room temperature after controlled-purity helium exposure, one specimen will be tested in the as-welded condition, and the tenth sample will be used as a spare.

Each of the completed side bend specimens were inspected radiographically for defects. It should be noted that two radiographs were produced for each sample, with specimens rotated $90^{\circ}$ about their longitudinal axis after the first exposure. This technique is capable of detecting a discontinuity which is approximately $2 \%$ of the thickness of the material. A few detects (generally fine porosity) were noted by this technique. These samples will be tested in the as-welded condition or used as spares. As-welded side bend tests will be conducted during the next quarter.

\subsection{TASK. 3 - TESTING AND ANALYSIS FACILITIES AND EQUIPMENT}

\subsubsection{Multispecimen Creep (MSC) Equipment}

Helium leakage detected during an attempt to restart the $9.50{ }^{\circ} \mathrm{C}$ test in $\mathrm{MS}-6$ led to the identification of cracks in the ceramic retort. The leak was detected before the specimens reached $200^{\circ} \mathrm{C}$. The cracks were circumferential, as much as $10 \mathrm{~cm}$ ( 3.9 inches) in length, and were found over a $15 \mathrm{~cm}$ ( 5.9 inches) length of retort corresponding to the location of the bottom heating element of the furnace. The cracked tube was removed. 


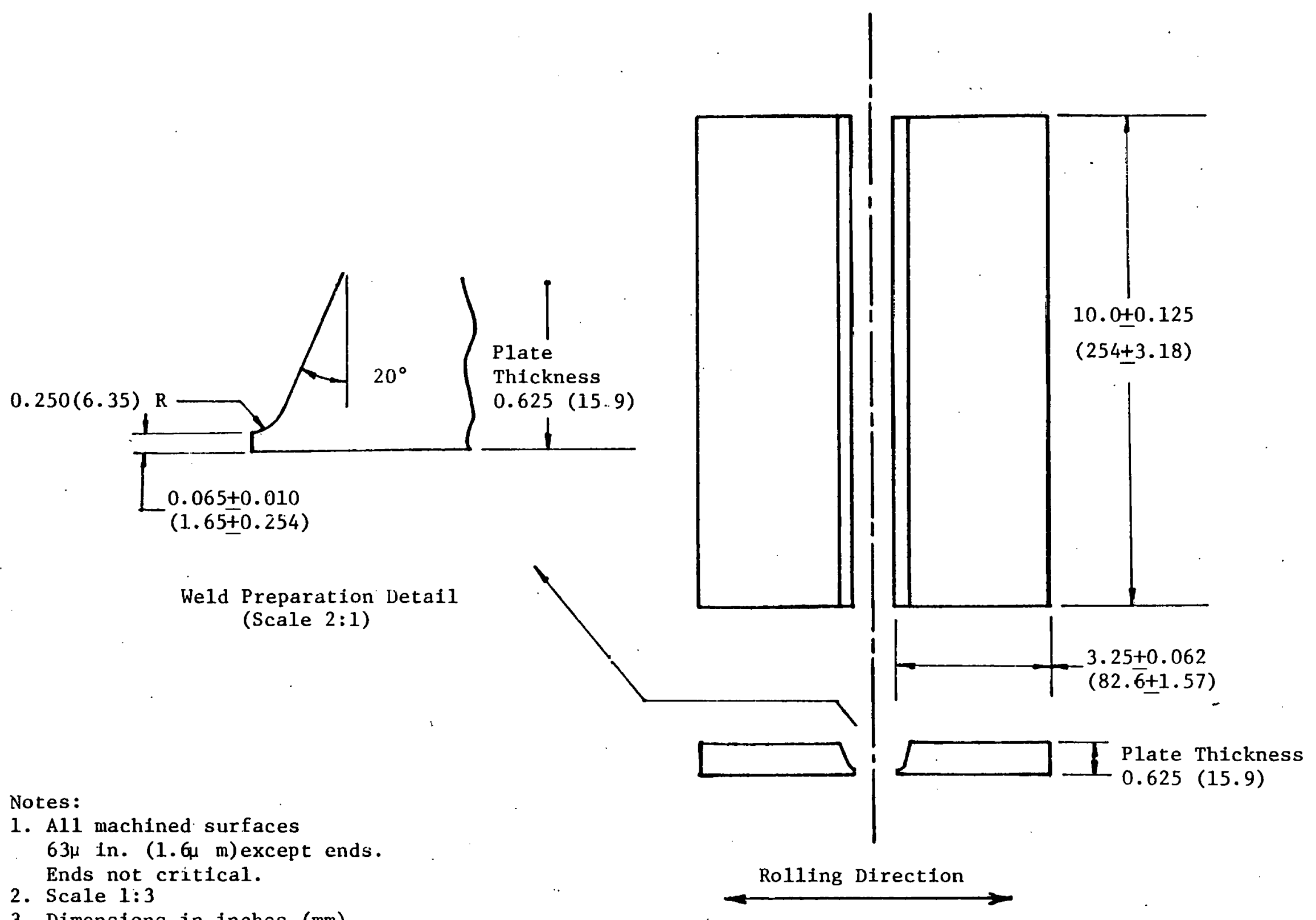

,Figure 1. Geometry of Wrought Plate Butt Weldments. 
PARAMETERS EMPLOYED IN THE FABRICATION OF WELDMENTS FOR PHASE 2 TESTING

Base Metal/Filler Metal

Alloy $800 \mathrm{H} /$ Inconel

Filler Metal 82

Inconel 617/Inconel

Filler Metal 617

Hastelloy $\mathrm{X} /$ Hastelloy $\mathrm{X}$

Filler Metal

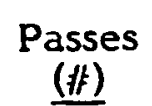

18

1st: $145-150$

Others: $150-160$

17

$140-160$

Current

(Amps)

Voltage

(volts)

$16-18$

$16-18$

14

$140-150$

16 
The cracked alumina tube in MS- 6 was replaced with an Inconel 601 retort supplied by Applied Test Systems (ATS). At the end of the report period this tube was in position, ready for conditioning (preoxidation). This retort tube change also necessitated another furnace change, back to the original hot-zone length design which has performed satisfactorily in the $750^{\circ}$ and $850^{\circ} \mathrm{C}$ tests to date.

Three of the four multispecimen creep stands used for helium tests have been modified to accommodate two thermocouple probes for each of the five furnace zones. The original construction provided one $\mathrm{T} / \mathrm{C}$ per zone with one additional T/C for an over-temperature trip circuit. The four added $T / C^{\prime} s$ will allow all-zone over-temperature protection. Extra T/C's had been added to $\mathrm{MS}-2\left(1050^{\circ} \mathrm{C}\right.$ tests), MS-4 ( $750^{\circ} \mathrm{C}$ tests), and MS-6 $\left(950^{\circ} \mathrm{C}\right.$ tests) by the end of the report period. MS-1 $\left(850^{\circ} \mathrm{C}\right.$ tests) will be similarly modified during its scheduled shutdown in July for specimen measurements after 5000-hours of testing.

During a preliminary run to establish the temperature profile in MS-6, prior to resumption of the $950^{\circ} \mathrm{C}$ tests, the center heating element burned out. The furnace was removed, shipped to ATS for repair, and replaced by a reduced hot-zone length furnace. Slightly heavier wire will be used during rewinding to help increase furnace life. This is the first furnace burn-out for any of the MS stands.

\subsubsection{Thermal Stability [Aging/Corrosion (A/C)] Test Equipment}

All of the retorts have been equipped with additional thermocouples as described above for the multispecimen creep stands. The two T/C;s for a given furnace zone are located at the same elevation in the vertical retort, but $180^{\circ}$ apart azimuthally. The control $\mathrm{T} / \mathrm{C}^{\prime} \mathrm{s}$ are maintained at the desired test temperature, generally within $\pm 0.5^{\circ} \mathrm{C}$. Checks of the second $\mathrm{T} / \mathrm{C}$ have shown that the temperature at its location can differ from the first $\mathrm{T} / \mathrm{C}$ by as much as $8^{\circ} \mathrm{C}$. It is believed that such differences are due to the irregularity of the furnace loads, that is that the heat transfer to a given $\mathrm{T} / \mathrm{C}$ is strongly influenced by its immediate surroundings at these temperatures where heat transfer is primarily by radiation. 
The cause of the cracks in the ceramic retort used for $1050^{\circ} \mathrm{C}$ exposures, reported in the Progress Report for period January 1, 1980 - March 31, 1980 (c00-2975-43) remains unknown. Detailed calculations of the steady state temperature drop across the retort wall (based on known power inputs and temperatures) indicate that induced thermal stresses probably do not exceed $3.45 \mathrm{MPa}$ ( $500 \mathrm{psi}$ ), which should be easily tolerated by the alumina. It seems, therefore, that cracking must be associated with transient stresses arising from the manner in which the furnaces are operated. It was recommended that specific temperature distributions be obtained experimentally before any further theoretical evaluation is attempted. It is possible that deta1led finite element modelling may be required to accurately assess the magnitude of these stress transients.

\subsubsection{Single Specimen Creep-Rupture (ST) Equipment}

Test stands ST-11 through ST-20 were conditioned and stands ST-21 through ST-30 were cleaned, reassembled, leak checked and readied for conditioning during the report period.

Furnace burn-outs in the $1050^{\circ} \mathrm{C}$ ST stands continue to be a concern. Several burned out furnace elements have been returned to the vendor, ATS, for repair. In order to address this problem, heavier winding wire and temperature control during cool down may have to be implemented. It is felt that thermal cycling of the furnaces, an unavoidable part of furnace function for testing use, is the major contributor to furnace element failure.

A series of tests on metallic and ceramic rod and tube extensometers have been initiated. Due to concern about the dimensional stability of metallic extensometers in the test atmosphere, tests have been designed to elucidate the nature of any dimensional changes, their magnitudes and time and temperature dependences. Ceramic extensometers also have been included in testing since they may provide a dimensionally stable alternative to metallic systems. Preliminary results indicate that the highest test temperature, $1050^{\circ} \mathrm{C}$, may be the most troublesome as far as dimensional changes are concerned. 
Several revisions have been incorporated in the prototype ceramic rod and tube extensometer after preliminary checkouts. These include:

1) Addition of a brace near the bottom (cold) ends of the tubes. This device maintains the rods parallel to the lower load bar and prevents rod and tube swinging in response to vibration. This was needed because of the necessarily loose nature of the joints between ceramic components and metal crossheads and results in elimination of "flutter" from the LVDT outputs.

2) Replacement of the vendor's. Inconel locking pin at these same ceramic/ crosshead joints. The replacement pin is $3 \mathrm{~mm}$ (.125. inch) dia alumina. This change was made after estimation of the shear stresses on the locking pin indicated significant creep would occur at $1050^{\circ} \mathrm{C}$.

3) Increased stiffness springs were installed in the LVDT's with the objective of keeping the slack out of the ceramic-to-metal joints during a test.

4) Shorter rods were procured after the first attempted test start was aborted due to insufficient remaining. LVDT travel after attaining test temperature. By the last week of June, the new ceramic rods had been machined to their proper length and the system was being recalibrated prior to start of the test.

\section{$\underline{2.3 .4}$ Fatigue Test Equipment}

During the report period, the assembly of the two closed-loop control electro-hydraulic test stands, environmental test chambers, load cells, hydraulic pumps, induction heaters, temperature control and readout connections, and liquid metal grip heating and cooling lines was completed. This completes the assembly of the test stands. Two check-out tests on dummy fatigue specimens have been successfully run.

\subsection{TASK 4 - SIMULATED REACTOR HELIUM ENVIRONMENT}

\subsubsection{Loop No. 1 Operation}

The average gas composition of the controlled-purity He for the report period is given in Table 6 . 
TABLE 6

Loop No. 1 Gas Chemistry History

April 1, 1980 to June 30,1980

Target Chemistry

$\&$ Normal Limils ( $\mu \mathrm{atm})$
Actual Average Chemistry

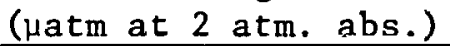

$\begin{array}{lcc}\mathrm{H}_{2} & 400 \pm 75 & 402 \\ \mathrm{H}_{2} \mathrm{O} & 2.0 \pm 1.0 & 2.2 \quad(\mathrm{a}) \\ \mathrm{CO} & 40 \pm 10 & 40.2 \\ \mathrm{CO}_{2} & 0.2 \pm 0.15 & 0.20 \\ \mathrm{CH}_{4} & 20 \pm 5 & 18.9 \\ \mathrm{~N}_{2} & 6 \pm 4 & 9.0 \\ \mathrm{He} & & \text { Balance }\end{array}$

(a) This number was determined by the EG\&G dew point hygrometer. 
Due to the criticality of maintaining invariant impurity gas levels in the helium supplied to the test specimens, retort inlet.and outlet chemistry has continued to be monitored and compared over the life of the test program. It is difficult to use retort outlet chemistries averaged over a period of time as a basis of comparison since these readings are taken less often than loop readings and are sensitive to normal fluctuation in the loop hellum gas impurity levels. For this reason, a comparison is made of inlet and outlet chemistries at specific points in time and the differences, compared. The two readings, inlet versus outlet, are usually made within an hour of one another. Table 7 lists the averages of the outlet minus the inlet impurity gas levels for the report period.

\subsubsection{Pumping, Purification and Analysis Station (PP\&A) No. I.}

There were no significant revisions or additions to this system during the report period.

\subsubsection{Pumping, Purification and Analysis Station (PP\&A) No. 2}

Loop No. 2 construction and leak checking operations were completed during the report period. The system was filled with helium and subjected to a brief check-out test. The check-out test uncovered some equipment problems, which are now being rectified.

Loop No. 2, capable of operating at any gas composition, will be used in the present program as a backup to Loop No. 1. Gas supply lines are being plumbed to facilitate this, and the capability of supplying controlled-purity helium to all the stands in the laboratory using either loop (presently $15 \mathrm{ST}$ stands cannot be supplied by Loop No. 1 and a different 15 ST stands cannot be supplied by Loop No. 2) will be done when the testing schedule and priorities permit.

\subsubsection{Fatigue Testing Gas Supply System}

The frame for the controlled-purity hel fum gas supply console was put in place. Connection of the gas purification train, impurity gas addition train, gauges, flowmeters and other auxiliary lines has been completed. The gas chromatograph and oxygen probe have also been installed, but the gas chromatograph was not operable by the end of the report period. The hygrometers and the gas supply and return lines to and from the retorts have yet to be installed. 
TABLE 7

Average Gas Chemistry Change, By Retort, April to June, 1980

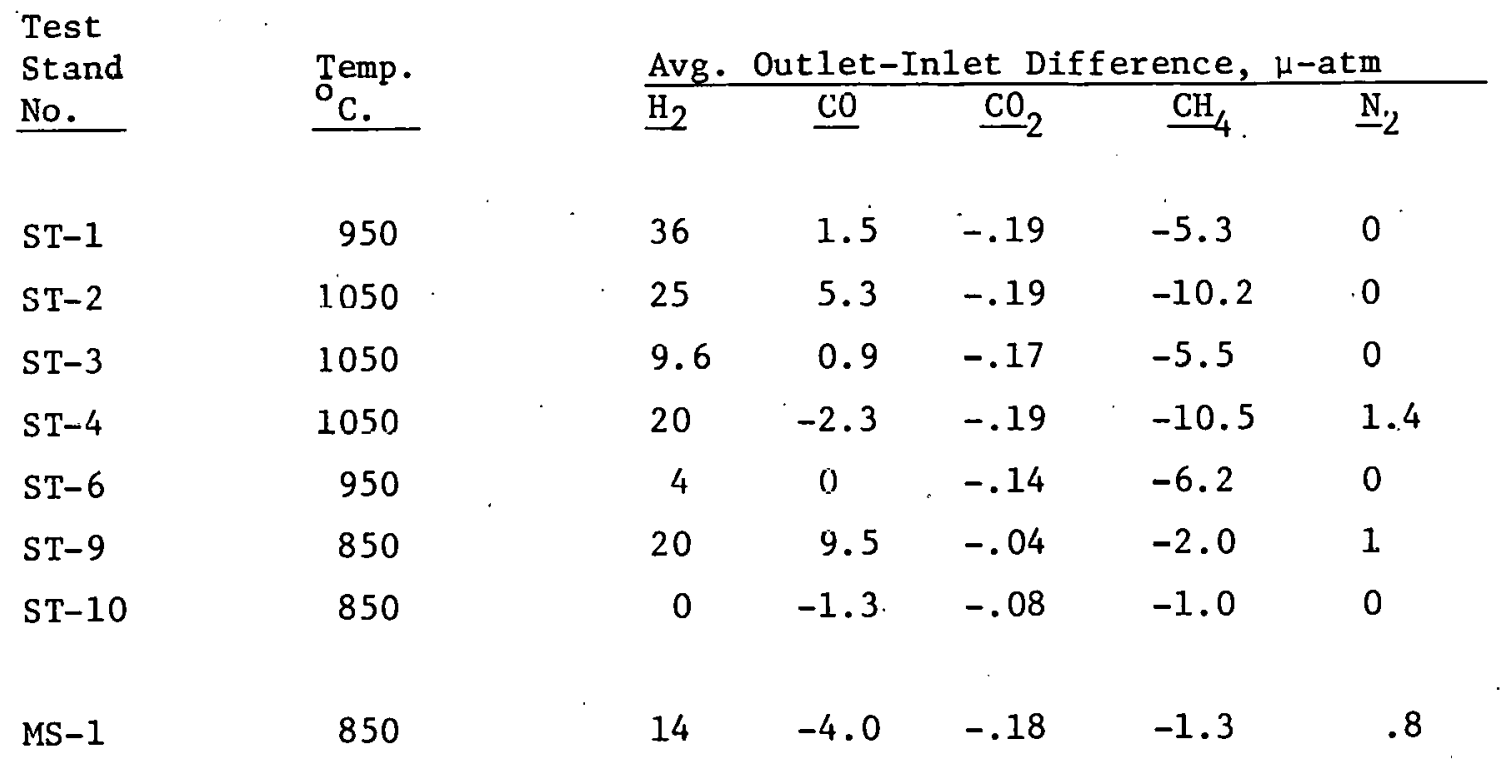




\subsection{TASK 5 - MECHANICAL PROPERTIES EVALUATION}

\subsubsection{Test Specimen Machining}

Machining of test specimens required for the screening test program was completed by September, 1978 .

The nuclear process heat (NPH) alloy specimens for Phase 2 testing have a11 been machined. These are test specimens from Alloy $800 \mathrm{H}$, Hastelloy $\mathrm{X}$, Inconel 617 and MA-956.

The machining of the direct cycle helium turbine (DCHT) alloys for Phase 2 testing has begun. The alloys are Rene' 100, Alloy 713LC and MA-754. In addition, some specimens are being machined from Alloy $713 \mathrm{C}$ for coating with Codep B. These specimens should be received for testing during the next quarterly reporting period, July to September, 1980.

\subsubsection{Screening Creep Testing}

Multispecimen creep results for the fourth 1000-hour test interval at $750^{\circ}$ and $850^{\circ} \mathrm{C}$ were obtained during the report period. Since several specimens are removed after 3000 hours on lest, the1r replacements have now accrued 1000 hours on test, and those results were also obtalned. Tables 8 and 9 give the results of room temperature strain measurements for the stated test conditions for the NPH alloys and the DCHT alloys, respectively. These tables include screening creep data which were previously reported.

No excessive creep strains were noted in this set of data. Comparison can now be made in some cases of the desired versus actual creep strains in some of the tests slated for 6000 hours. Stresses were selected to give $1 \%$ total strain in 6000 hours, but the actual stress on many of these specimens is somewhat less than the desired stress due to the limitations of multispecimen creep testing. (The actual versus desired stresses for all multispecimen creep testing were reported in the quarterly report for April 1, 1979 to June 30 , 1979 , report number $\mathrm{C} 00-2975-34$.) At $750^{\circ} \mathrm{C}$, five $\mathrm{NPH}$ alloys, 
SCREENING (MULTISPECIMEN) CREEP RESUULTS FOR THE NUCLEAR PROCESS HEAT ALLOYS

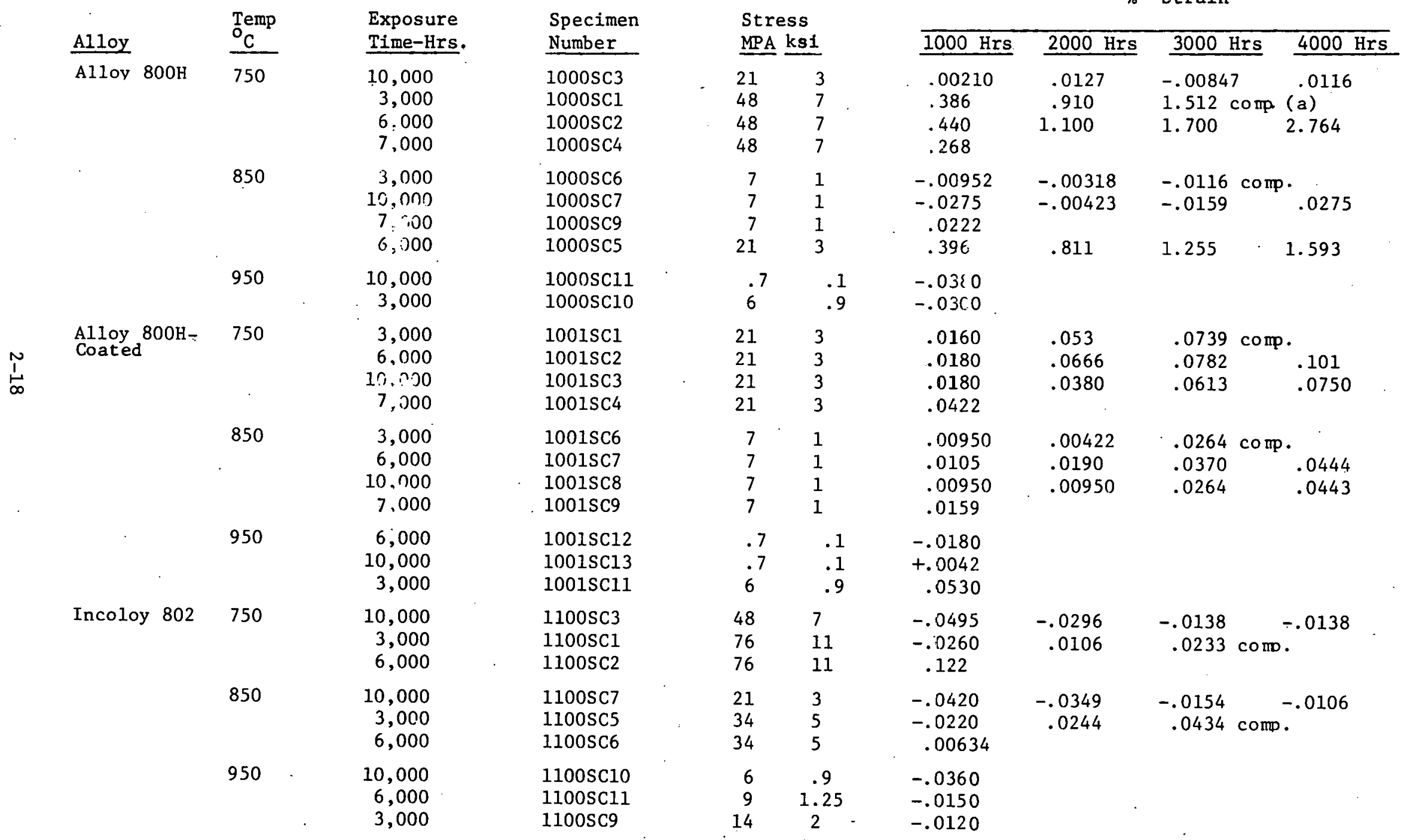

(a) comp. - complete; these specimens have reached their planned exposure time and have been removed from test. 
TABL 8 (continued)

SCREENING (MULTISPECIMEN) CREEP RESULTS FOR THE NUCLEAR PROCESS HEAT ALLOYS

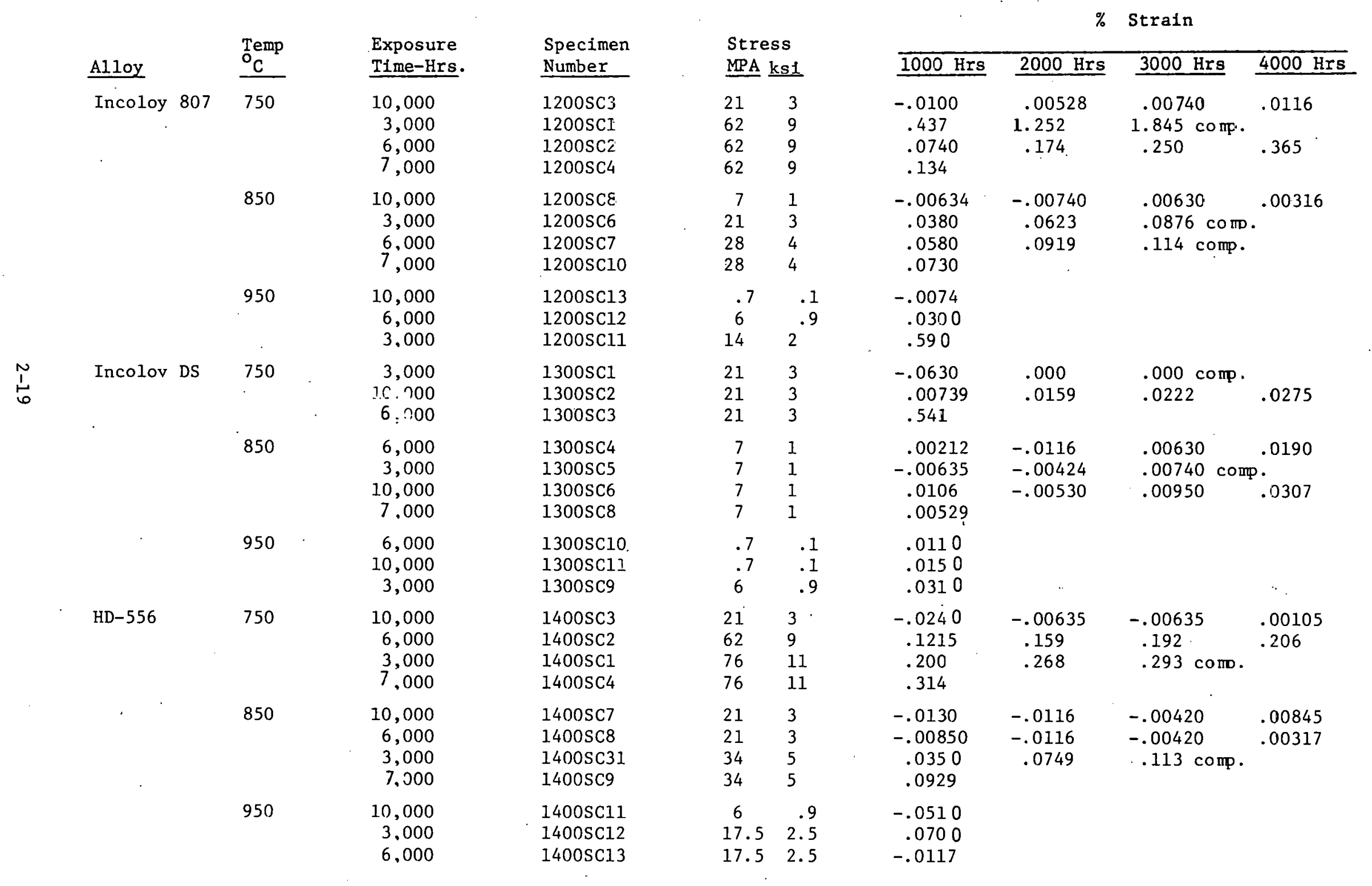


TAB LE 8 (continued)

SCREENING (MULTISPECIMEN) CREEP RESULTS FOR THE NUCLEAR PROCESS HEAT ALLOYS

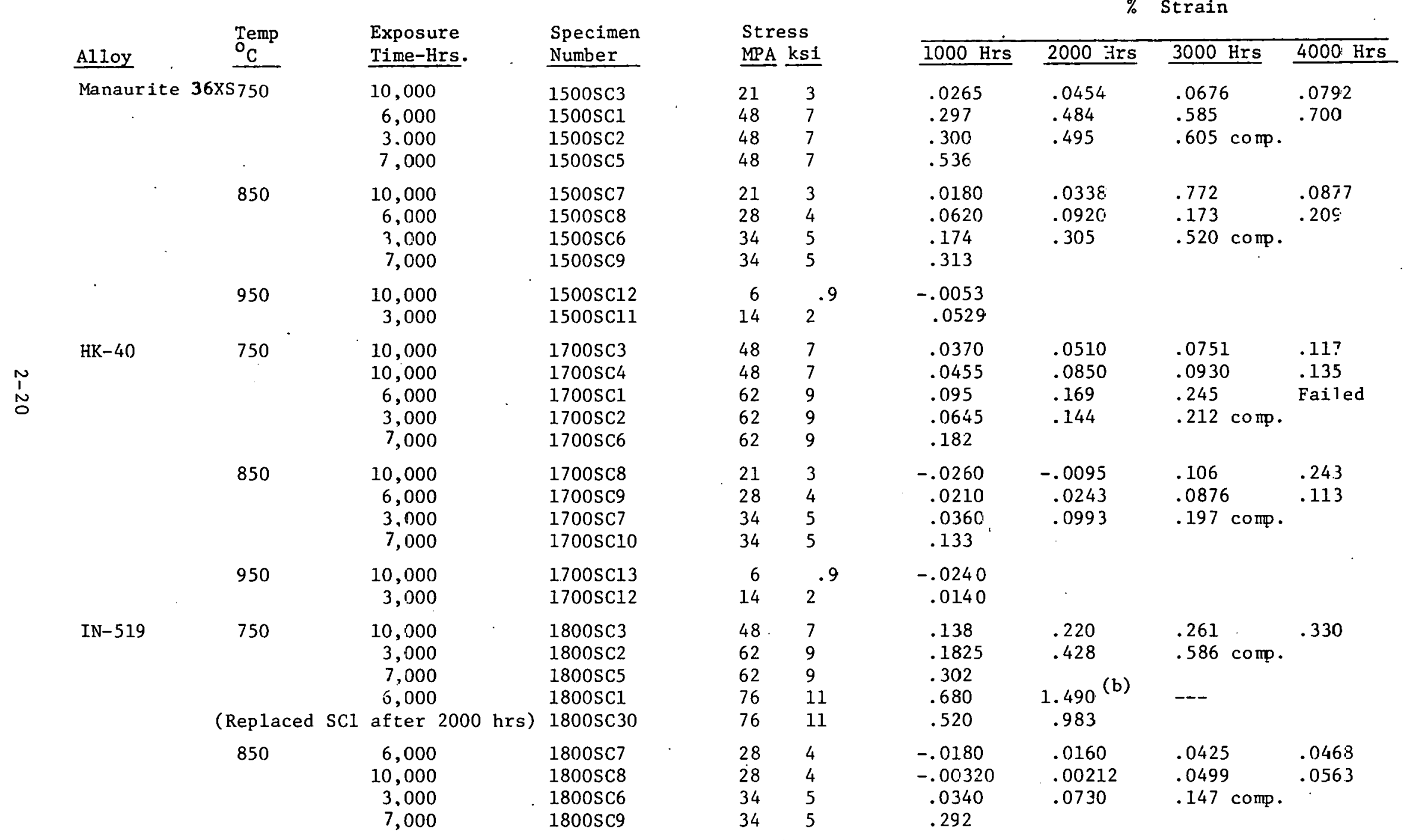

(b) replaced do to ding found in gage section. 
TABLE 8 (continued)

SCREENING (MULTISPECIMEN) CREEP RESULTS FOR THE NUCLEAR PROCESS HEAT ALLOYS

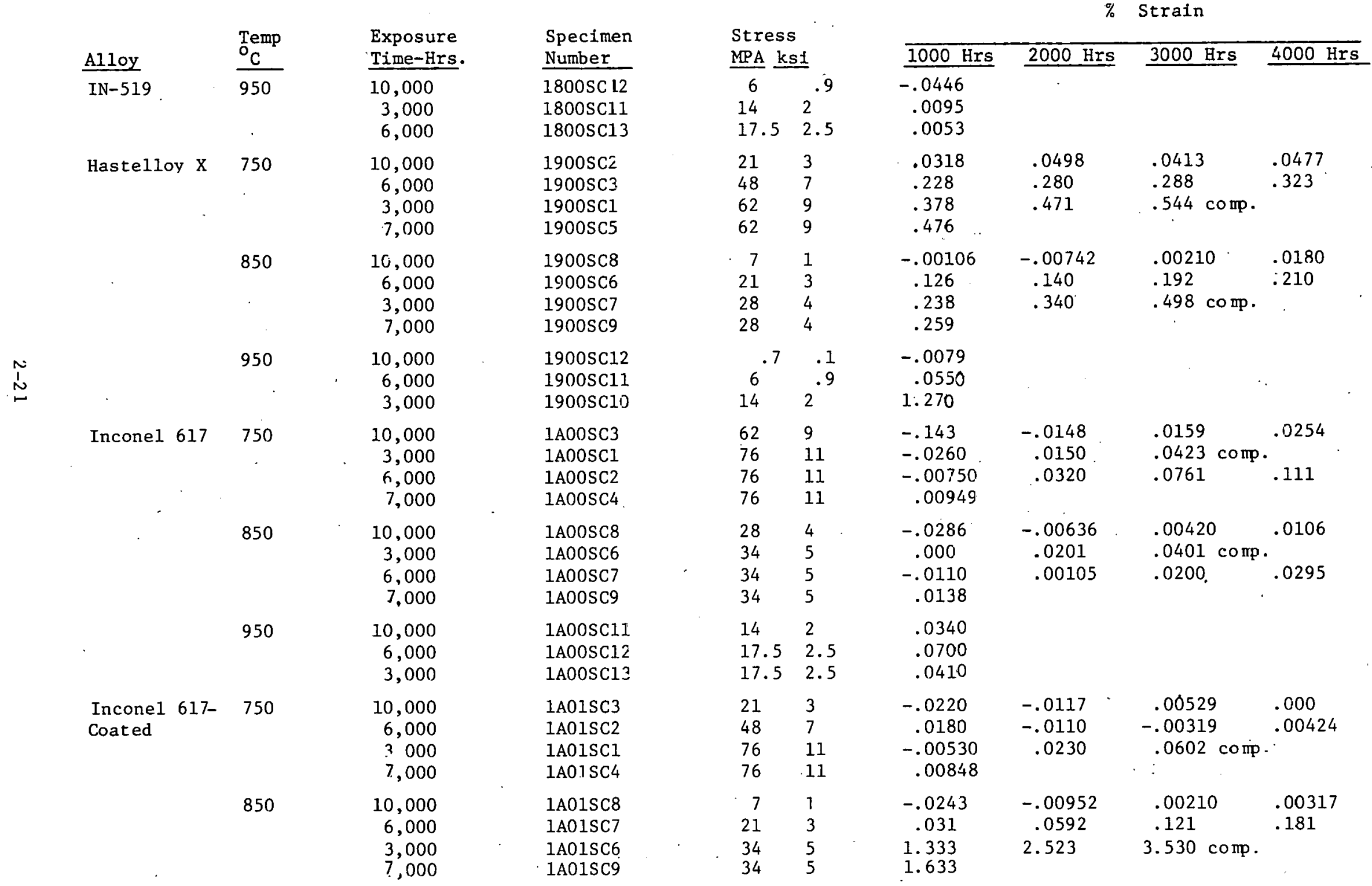


TABLE $\& \quad$ (continued)

SCREENING (MULTISPECIMEN) CREEP RESULTS FOR THE NUCLEAR PROCESS HEAT ALLOYS

\begin{tabular}{|c|c|c|c|c|c|c|c|c|c|c|c|}
\hline \multirow{2}{*}{\multicolumn{2}{|c|}{ AIloy }} & \multirow[b]{2}{*}{$\begin{array}{l}\text { Temp } \\
{ }^{\circ} \mathrm{C} \\
\end{array}$} & \multirow[b]{2}{*}{$\begin{array}{l}\text { Exposure } \\
\text { Time-Hrs. }\end{array}$} & \multirow[b]{2}{*}{$\begin{array}{l}\text { Specimen } \\
\text { Number }\end{array}$} & \multirow{2}{*}{\multicolumn{2}{|c|}{$\begin{array}{l}\text { Stress } \\
\text { MPA ksi }\end{array}$}} & \multicolumn{2}{|r|}{$\%$} & \multicolumn{3}{|l|}{ Strain } \\
\hline & & & & & & & $1000 \mathrm{Hrs}$ & 2000 Hrs & $3000 \mathrm{H}$ & Hrs & $4000 \mathrm{Hrs}$ \\
\hline - & $\begin{array}{l}\text { Inconel } 617 \\
\text { coated }\end{array}$ & 950 & $\begin{array}{r}10,000 \\
6,000 \\
3,600\end{array}$ & $\begin{array}{l}1 \mathrm{AO} 1 \mathrm{SC} 13 \\
1 \mathrm{~A} 02 \mathrm{SC} 12 \\
1 \mathrm{A01SC11}\end{array}$ & $\begin{array}{c}.7 \\
9 \\
14\end{array}$ & $\begin{array}{l}.1 \\
1.25\end{array}$ & $\begin{array}{l}.0160 \\
.0500 \\
.160\end{array}$ & & & & \\
\hline & Mo-Re 2 & $\begin{array}{c}750 \\
. \\
.\end{array}$ & $\begin{array}{r}10,600 \\
3,(100 \\
6,600 \\
7,500\end{array}$ & $\begin{array}{l}1 \operatorname{coosc} 3 \\
1 \operatorname{coosc} 2 \\
1 \operatorname{coosc} 1 \\
1 \operatorname{coosc} 4\end{array}$ & $\begin{array}{l}48 \\
76 \\
76 \\
76\end{array}$ & $\begin{array}{l}7 \\
11 \\
11 \\
11\end{array}$ & $\begin{array}{l}.304 \\
.680 \\
.703 \\
.844\end{array}$ & $\begin{array}{l}.360 \\
.790 \\
.811\end{array}$ & $\begin{array}{l}.375 \\
.836 \\
.870\end{array}$ & comp. & $\begin{array}{l}.397 \\
.937\end{array}$ \\
\hline & & 850 & $\begin{array}{r}10,000 \\
6,000 \\
3,000 \\
7,000\end{array}$ & $\begin{array}{l}1 \operatorname{coosc} 11 \\
1 \operatorname{coosc} 39 \\
1 \operatorname{coosc} 8 \\
1 \operatorname{coosc} 12\end{array}$ & $\begin{array}{l}28 \\
34 \\
34 \\
34\end{array}$ & $\begin{array}{l}4 \\
5 \\
5 \\
5\end{array}$ & $\begin{array}{l}.166 \\
.166 \\
.198 \\
.393\end{array}$ & $\begin{array}{l}.191 \\
.222 \\
.236\end{array}$ & $\begin{array}{l}.224 \\
.290 \\
.299\end{array}$ & comp. & $\begin{array}{l}.240 \\
.300\end{array}$ \\
\hline Ñ & & 950 & $\begin{array}{r}10,300 \\
3,300 \\
6,300\end{array}$ & $\begin{array}{l}1 \mathrm{COOSC} 14 \\
1 \mathrm{C} 00 \mathrm{SC} 15 \\
1 \mathrm{C} 00 \mathrm{SC} 16\end{array}$ & $\begin{array}{l}14 \\
17.5 \\
17.5\end{array}$ & $\begin{array}{l}2 \\
2.5 \\
2.5\end{array}$ & $\begin{array}{l}.146 \\
.176 \\
.143\end{array}$ & & & & \\
\hline & MA-956 & 850 & $\begin{array}{r}6,000 \\
10,000 \\
3.000 \\
7,000\end{array}$ & $\begin{array}{l}1 \mathrm{D} 00 \mathrm{SC} 1 \\
1 \mathrm{D} 00 \mathrm{SC} 2 \\
1 \mathrm{D} 00 \mathrm{SC} 3 \\
1 \mathrm{D} 00 \mathrm{SC} 5\end{array}$ & $\begin{array}{l}42 \\
42 \\
55 \\
55\end{array}$ & $\begin{array}{l}6 \\
6 \\
8 \\
8\end{array}$ & $\begin{array}{l}.0100 \\
.0290 \\
.00880 \\
.00589\end{array}$ & $\begin{array}{l}.0220 \\
.0412 \\
.0293\end{array}$ & $\begin{array}{r}.0235 \\
.0412 \\
.0293\end{array}$ & comp. & $\begin{array}{l}.00733 \\
.0324\end{array}$ \\
\hline & & 950 & $\begin{array}{r}6,000 \\
10,000\end{array}$ & $\begin{array}{l}1 \mathrm{D} 00 \mathrm{SC} 7 \\
1 \mathrm{D} 00 \mathrm{SC} 8\end{array}$ & $\begin{array}{l}34 \\
34\end{array}$ & $\begin{array}{l}5 \\
5\end{array}$ & $\begin{array}{l}.0410 \\
.0180\end{array}$ & & & & \\
\hline
\end{tabular}


TABLE 9

SCREENING (MULTISPECIMEN) CREEP RESULTS FOR THE DIRECT CYCLE HELIUM TURB INE ALLOYS

\begin{tabular}{|c|c|c|c|c|c|c|c|c|c|c|c|}
\hline A11oy & $\begin{array}{l}\text { Temp } \\
{ }_{\mathrm{C}} \mathrm{C} \\
\end{array}$ & $\begin{array}{l}\text { Exposure } \\
\text { Time-Hrs. }\end{array}$ & $\begin{array}{l}\text { Specimen } \\
\text { Number } \\
\end{array}$ & $\begin{array}{l}\text { Str } \\
\text { MPA } \\
\end{array}$ & $s$ & $1000 \mathrm{Hrs}$ & $2000 \mathrm{Hrs}$ & 3000 & Hrs & 4000 & Hrs \\
\hline \multirow[t]{2}{*}{ TZM } & 750 & $\begin{array}{r}10,000 \\
6,000 \\
3,000 \\
6,000\end{array}$ & $\begin{array}{l}\operatorname{Co1SC} 16 \\
\operatorname{Colsc17} \\
\operatorname{colsc} 19 \\
\operatorname{colsc} 20\end{array}$ & $\begin{array}{l}345 \\
345 \\
345 \\
345\end{array}$ & $\begin{array}{l}50 \\
50 \\
50 \\
50\end{array}$ & $\begin{array}{l}.0439 \\
.0580 \\
.0410 \\
.0512\end{array}$ & $\begin{array}{r}.0548 \\
.0713 \\
.0524\end{array}$ & $\begin{array}{l}.0495 \\
.0799 \\
.0609\end{array}$ & comp. & $\begin{array}{l}.0538 \\
.0856 \\
\text { (a) }\end{array}$ & \\
\hline & 850 & $\begin{array}{r}6,000 \\
3,000 \\
10,000 \\
6,000\end{array}$ & $\begin{array}{l}\text { coosc1 } \\
\text { coosc2 } \\
\text { coosc } 3 \\
\text { coosc5 }\end{array}$ & $\begin{array}{l}152 \\
152 \\
152 \\
152\end{array}$ & $\begin{array}{l}22 \\
22 \\
22 \\
22\end{array}$ & $\begin{array}{l}.0225 \\
.00857 \\
.00288 \\
.0170\end{array}$ & $\begin{array}{l}.0183 \\
.00714 \\
.00144\end{array}$ & $\begin{array}{l}.0183 \\
.0012 \\
.0072\end{array}$ & 9 cotp & $\begin{array}{l}.0254 \\
.0354\end{array}$ & \\
\hline \multirow[t]{2}{*}{ MA- 754} & 850 & $\begin{array}{r}6,000 \\
10,000 \\
3,000 \\
6,000\end{array}$ & $\begin{array}{l}\mathrm{B} 00 \mathrm{SC} 1 \\
\mathrm{~B} 00 \mathrm{SC} 2 \\
\mathrm{~B} 00 \mathrm{SC} 3 \\
\mathrm{~B} 00 \mathrm{SC} 5\end{array}$ & $\begin{array}{l}110 \\
110 \\
110 \\
110\end{array}$ & $\begin{array}{l}16 \\
16 \\
16 \\
16\end{array}$ & $\begin{array}{l}.0660 \\
.0660 \\
.0636 \\
.0297\end{array}$ & $\begin{array}{r}.0663 \\
.0692 \\
.0537\end{array}$ & $\begin{array}{l}.0945 \\
.109 \\
.0876\end{array}$ & co Ip. & $\begin{array}{l}.107 \\
.105\end{array}$ & \\
\hline & 950 & $\begin{array}{r}6,000 \\
10,000 \\
3,000\end{array}$ & $\begin{array}{l}\text { B } 00 S C 6 \\
\text { B } 60 S C 7 \\
\text { B } 00 S C 8\end{array}$ & $\begin{array}{l}48 \\
48 \\
48\end{array}$ & $\begin{array}{l}7 \\
7 \\
7\end{array}$ & $\begin{array}{l}.0180 \\
.0226 \\
.0085\end{array}$ & $\therefore$ & & & & \\
\hline \multirow[t]{3}{*}{ MM-0011 } & 750 & $\begin{array}{r}10,000 \\
10,000 \\
6,000 \\
3,000 \\
6,000 \\
6,000\end{array}$ & $\begin{array}{l}100 \mathrm{SC} 1 \\
100 \mathrm{SC} 31 \\
100 \mathrm{SC} 7 \\
100 \mathrm{SC} 19 \\
100 \mathrm{SC} 32 \\
100 \mathrm{SC} 8\end{array}$ & $\begin{array}{l}262 \\
262 \\
345 \\
345 \\
345 \\
345\end{array}$ & $\begin{array}{l}38 \\
38 \\
50 \\
50 \\
50 \\
50\end{array}$ & $\begin{array}{l}.0130 \\
.0100 \\
.0584 \\
.0385 \\
.0370 \\
.0327\end{array}$ & $\begin{array}{r}.0356 \\
.0428 \\
.0869 \\
.0898 \\
.0754\end{array}$ & $\begin{array}{l}.0541 \\
.0257 \\
.1367 \\
.1012 \\
.0869\end{array}$ & comp. & $\begin{array}{l}.0626 \\
.0399 \\
.160 \\
.137\end{array}$ & \\
\hline & 850 & $\begin{array}{r}10,000 \\
.6,000 \\
3,000 \\
3,000 \\
6,000 \\
6,000\end{array}$ & $\begin{array}{l}100 \mathrm{SC} 5 \\
100 \mathrm{SC} 2 \\
100 \mathrm{SC} 3 \\
100 \mathrm{SC} 4 \\
100 \mathrm{SC} 9 \\
100 \mathrm{SC} 24\end{array}$ & $\begin{array}{l}110 \\
152 \\
152 \\
152 \\
152 \\
152\end{array}$ & $\begin{array}{l}16 \\
22 \\
22 \\
22 \\
22 \\
22\end{array}$ & $\begin{array}{l}.0290 \\
.0650 \\
.0560 \\
.0830 \\
.0429 \\
.0200\end{array}$ & $\begin{array}{l}.063 \\
.0896 \\
.0915 \\
.106\end{array}$ & $\begin{array}{l}.0845 \\
.141 \\
.150 \\
.154\end{array}$ & $\begin{array}{l}\text { conp. } \\
\text { co mp. }\end{array}$ & $\begin{array}{l}.107 \\
.139 \\
.\end{array}$ & . \\
\hline & 950 & $\begin{array}{r}10,000 \\
3,000\end{array}$ & $\begin{array}{l}100 \mathrm{SC} 12 \\
100 \mathrm{SC} 11\end{array}$ & $\begin{array}{l}34 \\
48\end{array}$ & $\begin{array}{l}5 \\
7\end{array}$ & $\begin{array}{l}.0300 \\
.0440\end{array}$ & & & & & \\
\hline
\end{tabular}

(a) comp. - complete; these specimens have reached their planned exposure time and have been removed from test. 
TABLE 9 (continued)

SCREENING (MULTISPECIMEN) CREEP RESULTS FOR THE DIRECT CYCLE HELIUM TURBINE ALLOYS

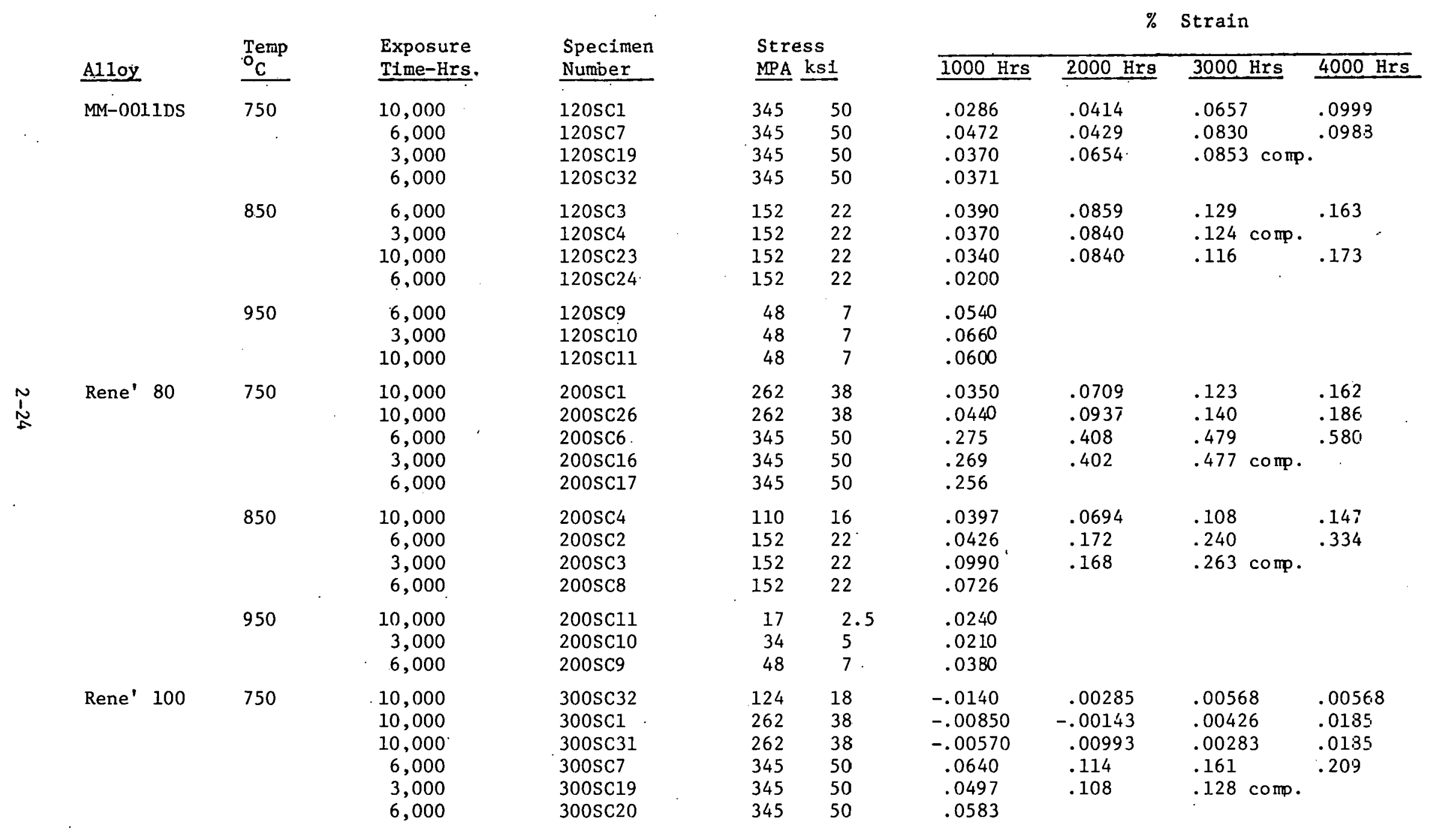


TABLE 9 (Continued)

SCREENING (MULTISPECIMEN) CREEP RESULTS FOR THE DIRECT CYCLE HELIUM TURBINE ALLOYS

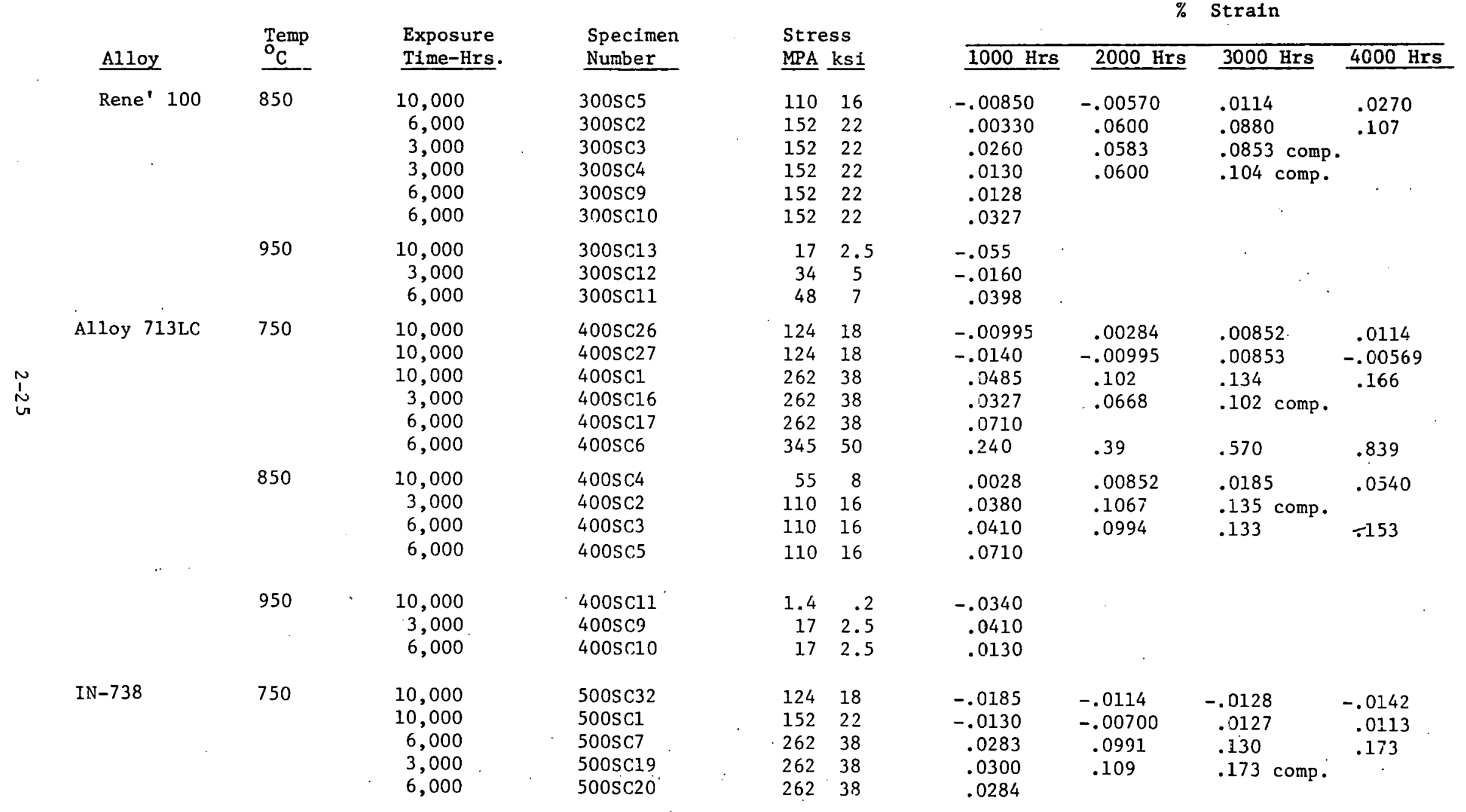


TABLE 9 (Continued)

SCREENING (MULTISPECIMEN) CREEP RESULTS FOR THE DIRECT CYCLE HELIUM TURBINE ALLOYS

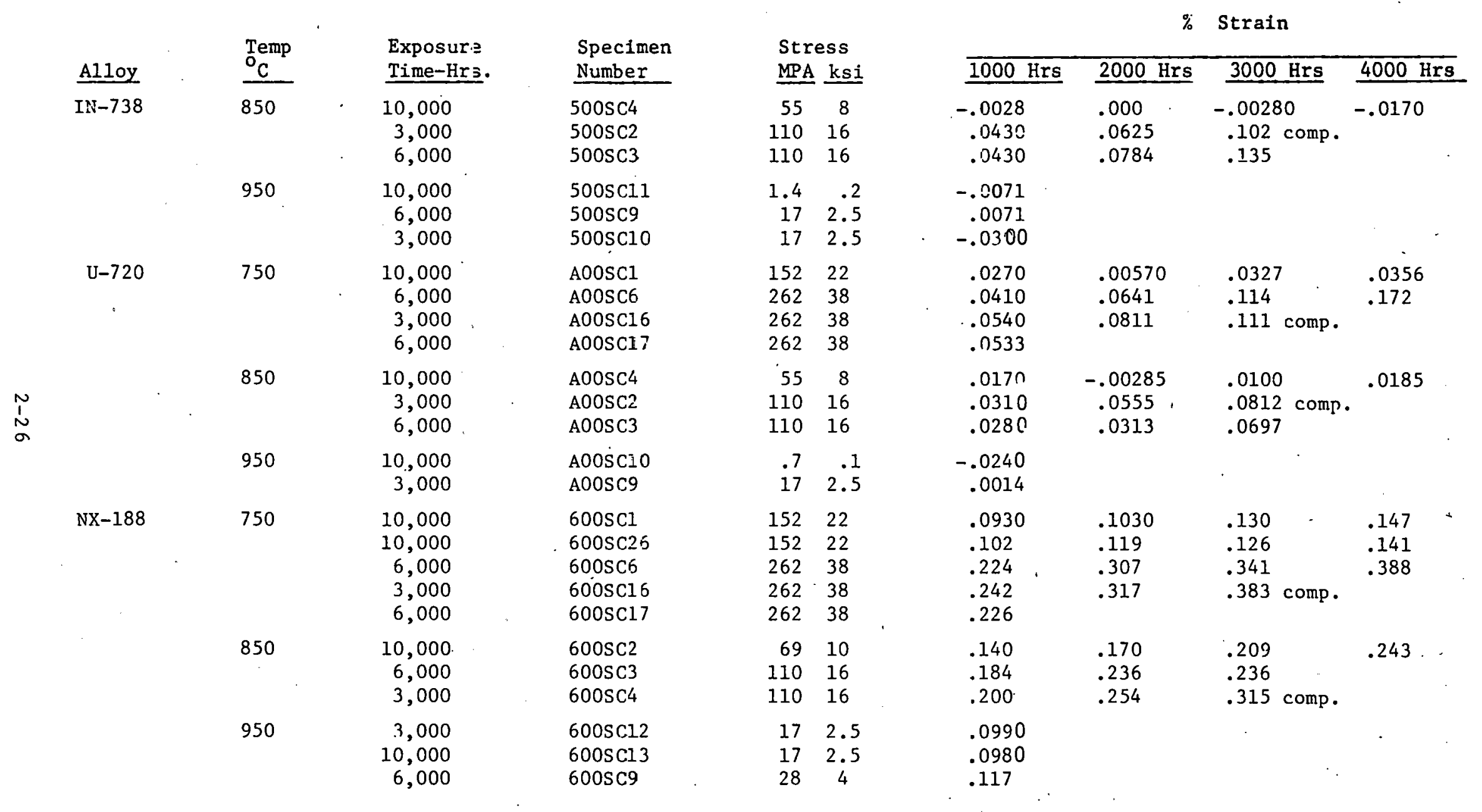


Alloy $800 \mathrm{H}$, Incoloy 807, HD-556, IN-519, and Mo-Re2, and one DCHT alloy, Rene' 80 are tested at $100 \%$ of the stress to give $1 \%$ total creep in 6,000 hours. At $850^{\circ} \mathrm{C}$, only Alloys $800 \mathrm{H}$ and Udimet 720 are tested at $100 \%$ of the desired stress for $1 \%$ total creep in 6,000 hours. For these alloys and temperatures, it is possible to review the 4,000 hour-test data with respect to the 6,000 -hour target. Alloy $800 \mathrm{H}$, for instance, had already passed the $1 \%$ total creep mark for the 6,000 hour specimens between 1,000 and 2,000 hours at $750^{\circ} \mathrm{C}$ and between 2,000 and 3,000 hours at $850^{\circ} \mathrm{C}$. Of the other $\mathrm{NPH}$ alloys at $750^{\circ} \mathrm{C}$, IN-519 is also creeping faster than expected; creep for Incoloy 807 and HD-556 is lower than expected; and Mo-Re 2 is right on target. Rene 80 at $750^{\circ} \mathrm{C}$ is also performing as expected, but Udimet 720 at $850^{\circ} \mathrm{C}$ has a lower creep rate than expected. In all cases, the creep levels fall within available scatter bands and cannot be viewed as excessively high for the high creep rates or low for low creep rates.

An $\mathrm{HK}-40$ sample $(1700 \mathrm{SC} 01)$ in the $750^{\circ} \mathrm{C}$ multispecimen creep furnace failed at 3,424 hours on test. This sample was being tested at $62 \mathrm{MPa}$ ( $9 \mathrm{ksi}$ ) and was scheduled for 6,000 hours of testing. Based upon original estimates, the (desired) stress of $69 \mathrm{MPa}(10 \mathrm{ksi})$ should have produced 1\% total strain in 6,000 hours. The actual stress level employed should have resulted in a rupture life of about 40,000 hours, based on air characterization tests of this heat. The strain measured on the specimen at 3,000 hours was $0.254 \%$. The fracture strain was measured as $1.3 \%$; however, the two pieces did not fit together well, so the actual strain would be lower. Reduction-in-area was approximately $1 \%$.

Post-fracture examination revealed that the fracture was interdendritic. Nothing unusual (such as porosity or non-metallic inclusions) was observed in the appearance of the fracture surface which could have contributed to premature failure. The microstructure was quite similar to that observed for the unstressed specimen exposed for 3,000 hours at $750^{\circ} \mathrm{C}$ in the same environment, except for a couple of voids, probably creep-induced, along dendrite boundaries near the fracture surface, and perhaps slightly more secondary carbide precipitation.

An additional point of interest is the behavior of certain specimens put on test at the 3,000-hour interval to replace those taken off test. These specimens have now reached 1,000 hours on test and their creep strain can be compared with the 1,000-hour strains measured on the specimens they replaced. 
For the DCHT alloys, the strains are similar. On the other hand, several of the replacement NPH specimens show significantly larger creep strains, up to an order of magnitude, when compared to their predecessors. The wrought iron-base alloys show the effect at $750^{\circ} \mathrm{C}$, while the effect is prevalent for the cast iron-base alloys at both $750^{\circ}$ and $850^{\circ} \mathrm{C}$. The strains for the replacement and origlnal wrought nickel-base alloy specimens are very similar, as is the case for the one ODS alloy. For the one nickel-base cast alloy, the strains are similar at $750^{\circ} \mathrm{C}$ but about a factor of two larger at $850^{\circ} \mathrm{C}$. The outstanding feature is that generally the creep strains are as large or larger than the previously tested specimens. The reason for this is not understood and is currently being investigated. When all the results are reviewed, that is the 4,000-hour as well as the 1,000-hour results for both groups of alloys, there is no evidence that the stresses are too high for the replacement specimens. The test atmosphere may be affected to some extent, since roughly two-thirds of the specimens have been on test for over 3,000 hours and no longer react with the atmosphere the way they did when new (i.e. depletion conditions may not be the same for the replacement specimens as for the original specimens).

\subsubsection{Phase 2 - Intensive Screening Creep-Rupture Testing}

All of the 24 air creep-rupture tests for the NPH alloys have been initiated. The results and test status at the end of the report period are shown in Table 10 . The results reveal no significant deviations from expected values, with the exception of the high creep rates shown by two Alloy $800 \mathrm{H}$ specimens (1000CR 19 and 1000CR09). Five specimens have ruptured so far, all stressed for 1,000-hour rupture lives. All of the rupture lives are within the scatterband of avallable air test data on the alloys.

\subsubsection{Impact Test Results}

Figures 2 and 3 show the appearance of the fracture surfaces of the Inconel 617 Charpy V-notch impact specimens tested to date.

The uncoated, as-received specimens show significant plastic deformation before fracture and exhibited a fibrous fracture appearance; the uncoated samples exposed to HTR helium at $750^{\circ}$ and $850^{\circ} \mathrm{C}$ had a completely intergranular fracture (Figure 2).

The coated samples exhibited intergranular fracture surfaces both as coated and after exposure to HTR helium (Figure 3). However, a ductile zone was evident around the rim of each specimen, below the coating. The ductile zone was thinner in the sample exposed at $750^{\circ} \mathrm{C}$ than in the as-received samples or in the sample exposed at $850^{\circ} \mathrm{C}$. 


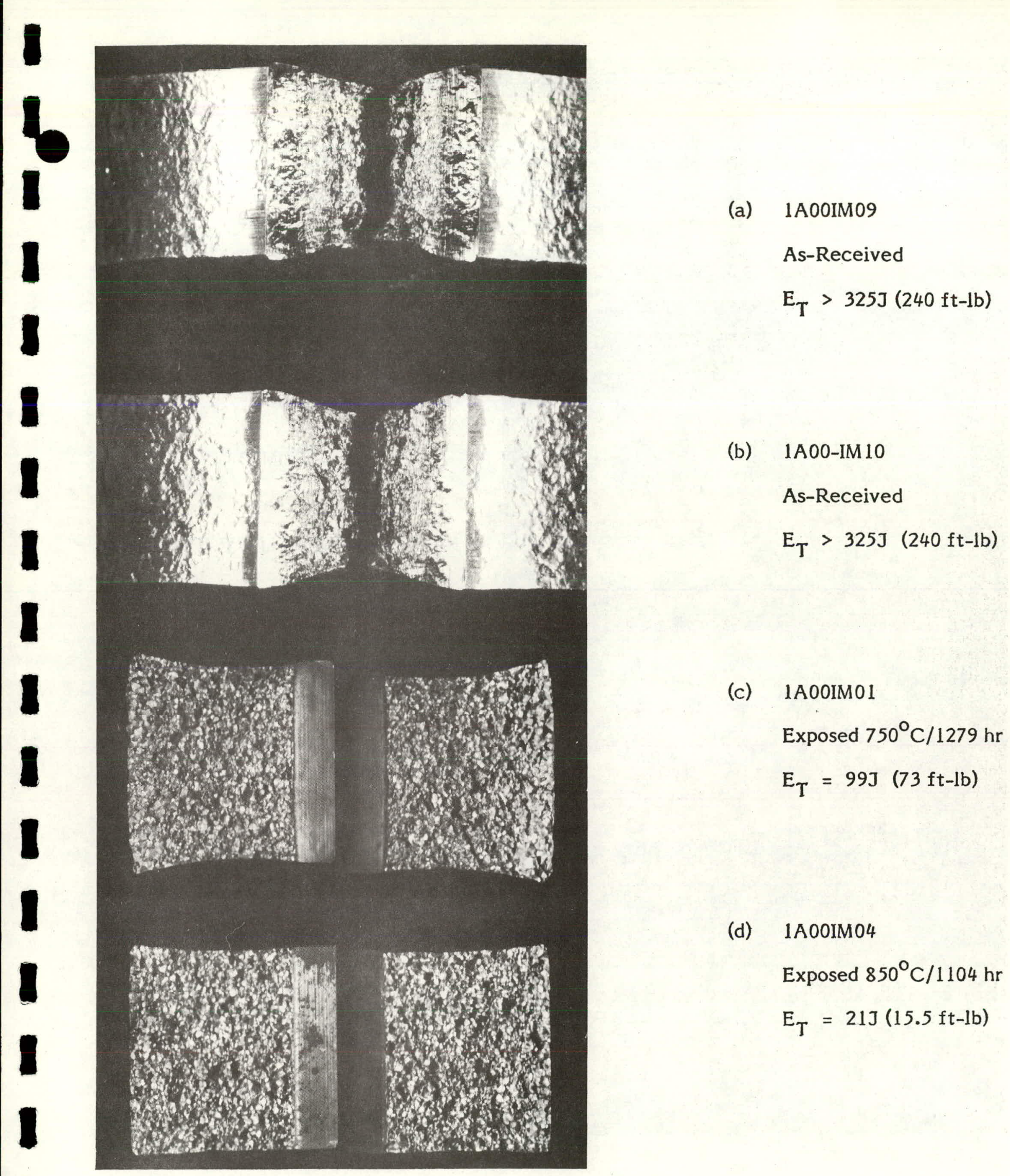

Figure 2. Fracture Surfaces of Uncoated Inconel 617 Charpy Impact Specimens. 


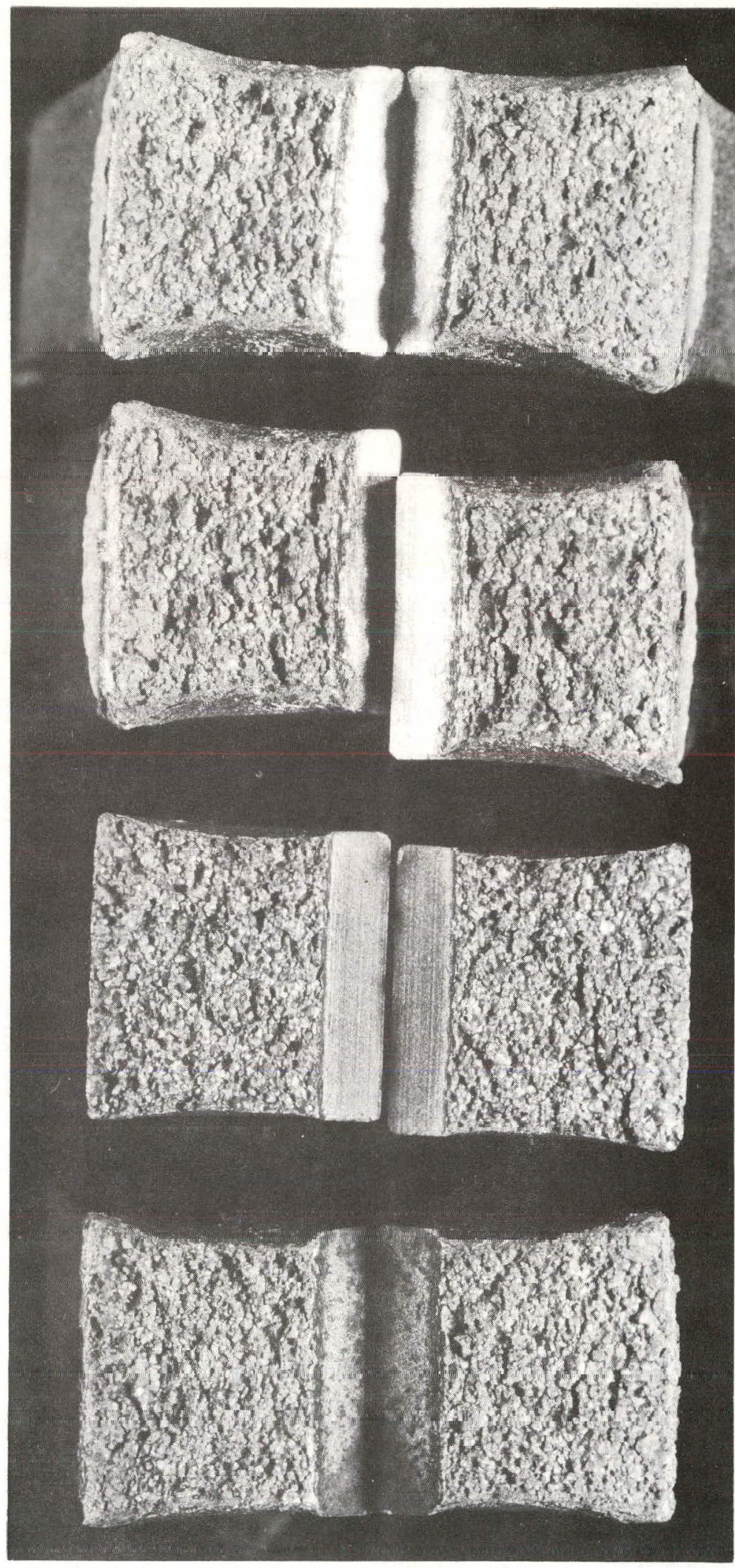
(a) 1A01IM02
As-Coated
$\mathrm{E}_{\mathrm{T}}=181 \mathrm{~J}(134 \mathrm{ft}-\mathrm{lb})$

(b) 1A01IM03

As-Coated

$\mathrm{E}_{\mathrm{T}}=187 \mathrm{~J}(138 \mathrm{ft}-\mathrm{lb})$

(c) 1A01IM01

Exposed $750^{\circ} \mathrm{C} / 1279 \mathrm{hr}$

$E_{T}=61 \mathrm{~J}(45 \mathrm{ft}-\mathrm{lb})$

(d) 1A0.1IM06

Exposed $850^{\circ} \mathrm{C} / 1104 \mathrm{hr}$

$E_{T}=111 J(87 \mathrm{ft}-\mathrm{lb})$

Figure 3. Fracture Surfaces of Coated Inconel 617

Charpy Impact Specimens. 
TABLE 10

PHASE 2 INTENSIVE SCREENING NUCLEAR PROCESS HEAT ALLOY AIR CREEP-RUPTURE TESTS

(STATUS AS OF $6 / 24 / 80$ )

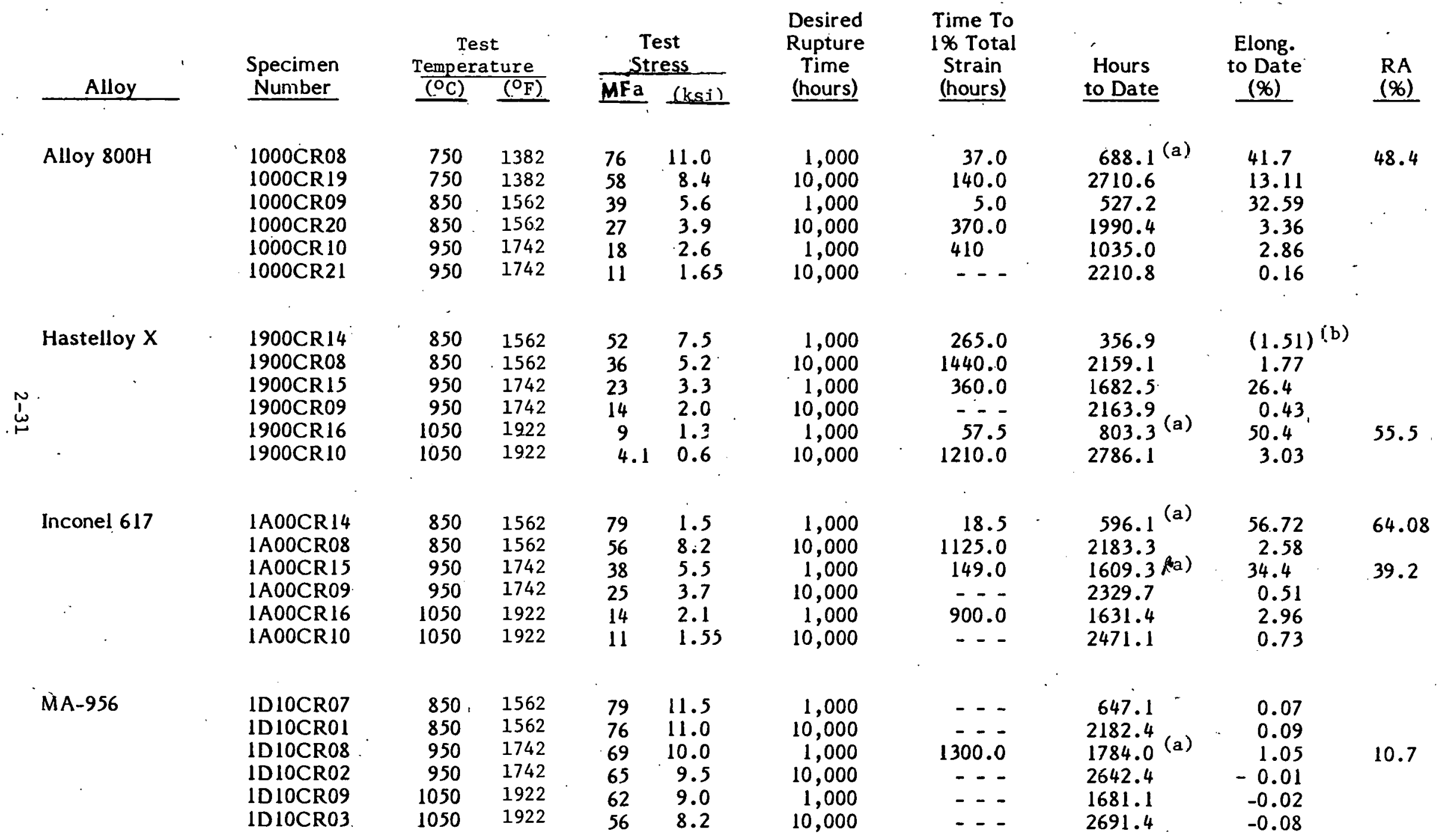

(a) Failed

(b) Sample had to be moved to new furnace. Test just restarted. Elongation listed is that at interruption of test. 
As discussed in the last Quarterly Report, this ductile zone appears to be due to the presence of the carbide-denuded zone beneath the coating, which was thinner in the sample exposed at $750^{\circ} \mathrm{C}$ than in the other samples.

The intergranular appearance is apparently due to the precipitation of carbides at grain boundaries during exposure or during the coating cycle. These carbides cause the lower impact values seen for the exposed or coated samples compared to the as-received, uncoated material. The higher impact energy seen for the coated sample exposed at $850^{\circ} \mathrm{C}$, as compared to the coated sample exposed at $750^{\circ} \mathrm{C}$, may be due to a larger carbide-denuded (ductile) zone present.

2.6 TASK $6 \& 7$ - THERMAL STABILITY EVALUATION AND PRIMARY COOLANT CORROSION RESISTANCE EVALUATION

Reported is the weight change information and metallographic results obtained for six NPH alloys after 3,000 hours at $750^{\circ} \mathrm{C}$. Due to an overtemperature problem at 2853 hours in Zones 1 and 2 (top two of five heating zones) of the furnace only Inconel 617, Inconel 618E, HK-40, Manaurite 36XS, Manaurite 900 and Mo-Re 2 specimens can be considered typical of 3,000 hours exposure at $750^{\circ} \mathrm{C}$. Structural stability exposures for 3,000 hours at $750^{\circ} \mathrm{C}$ will be repeated for the test of the alloys.

\subsubsection{Weight Change Results}

The $750^{\circ} \mathrm{C}$ controlled-purity helium weight change results obtained from unstressed structural stability specimens exposed for 3,000 hours have been analyzed during the past quarter. In addition, helium weight change data for specimens exposed at $950^{\circ} \mathrm{C}$ for 2,000 hours also have- been analyzed. The $950^{\circ} \mathrm{C}$ furnace $(\mathrm{A} / \mathrm{C}-2)$, was stopped at 2,000 hours to allow the 1,000 hour samples to be loaded.

The weight change results obtained to date are presented in Table 11 with the test time and weight change per unit surface area shown; along with the alloy and specimen number.

Plots for weight change versus aging time at $750^{\circ} \mathrm{C}$ for wrought iron-base, wrought nickel-base, centrifugally cast, and oxide dispersion strengthened alloys are shown in Figures 4 to 9, respectively. Each curve represents the data from different samples aged for $1,000,1,279,1,579$ (average of two samples) and 3,000 hours (for six alloys). 
TABLE 11

WEIGHT CHANGE RESULTS OF SPECIMENS AGED IN CONTROLLED-PURITY HELIUM

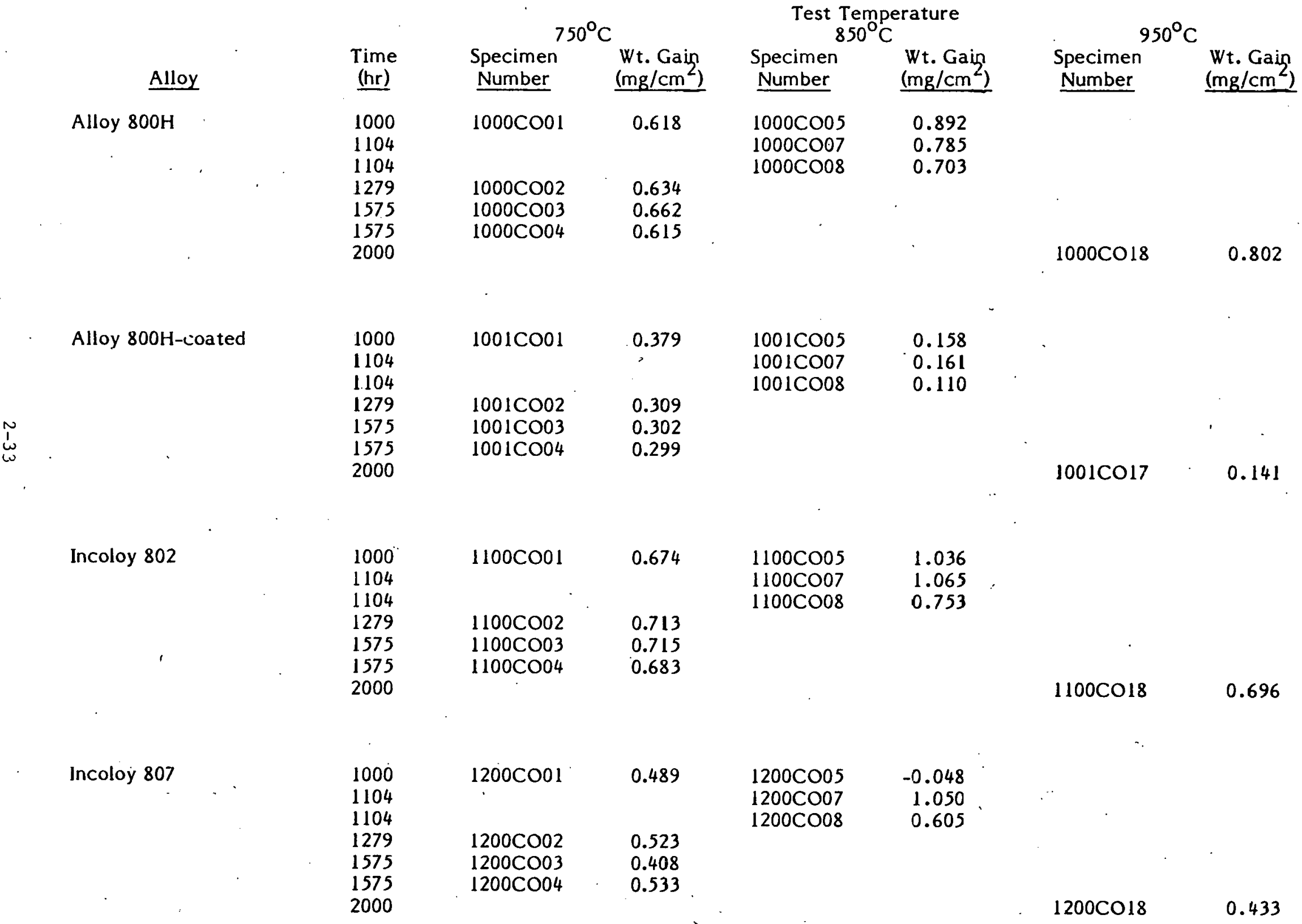


TABLE 11 (continued)

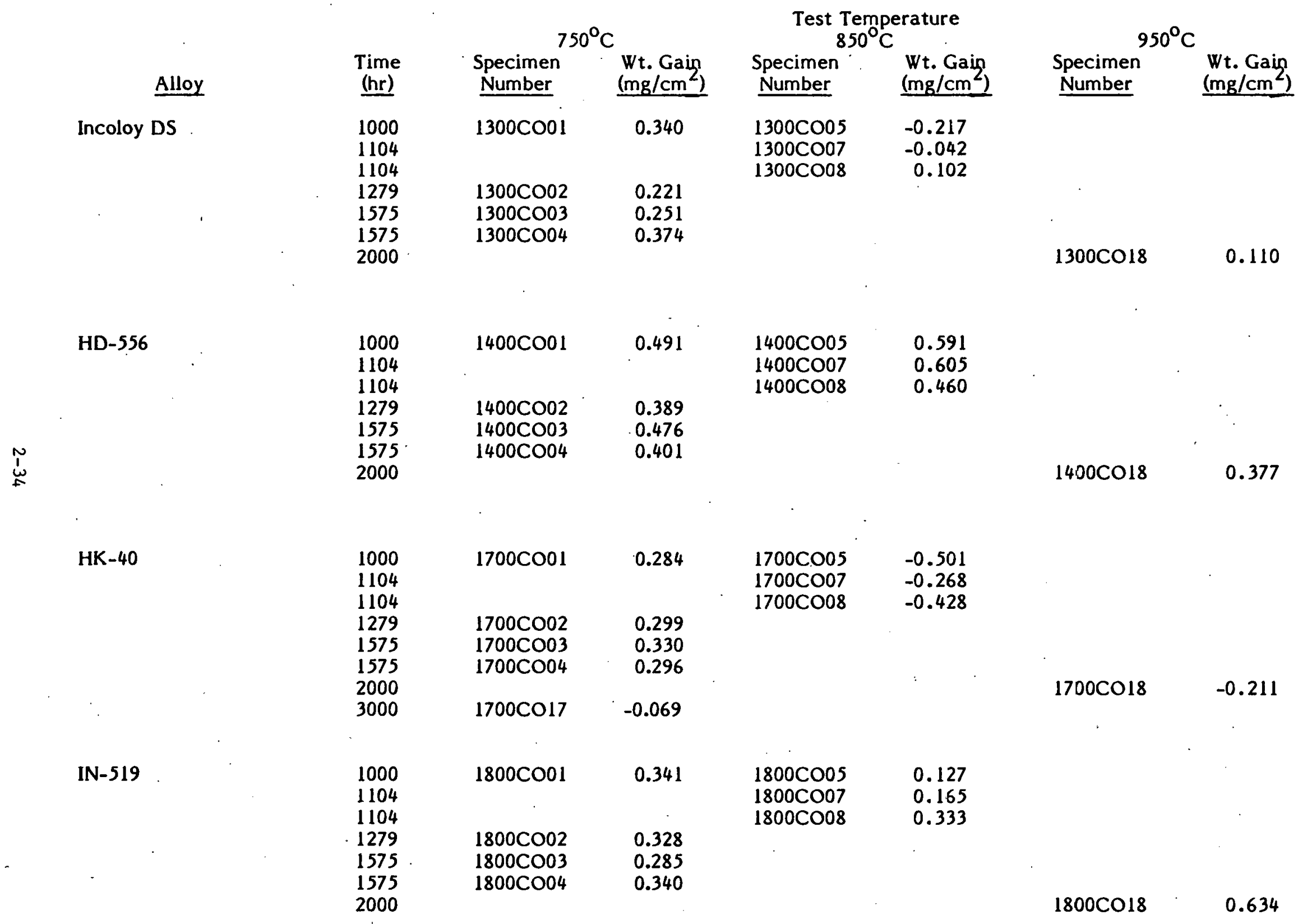


TABLE 11 (continued)

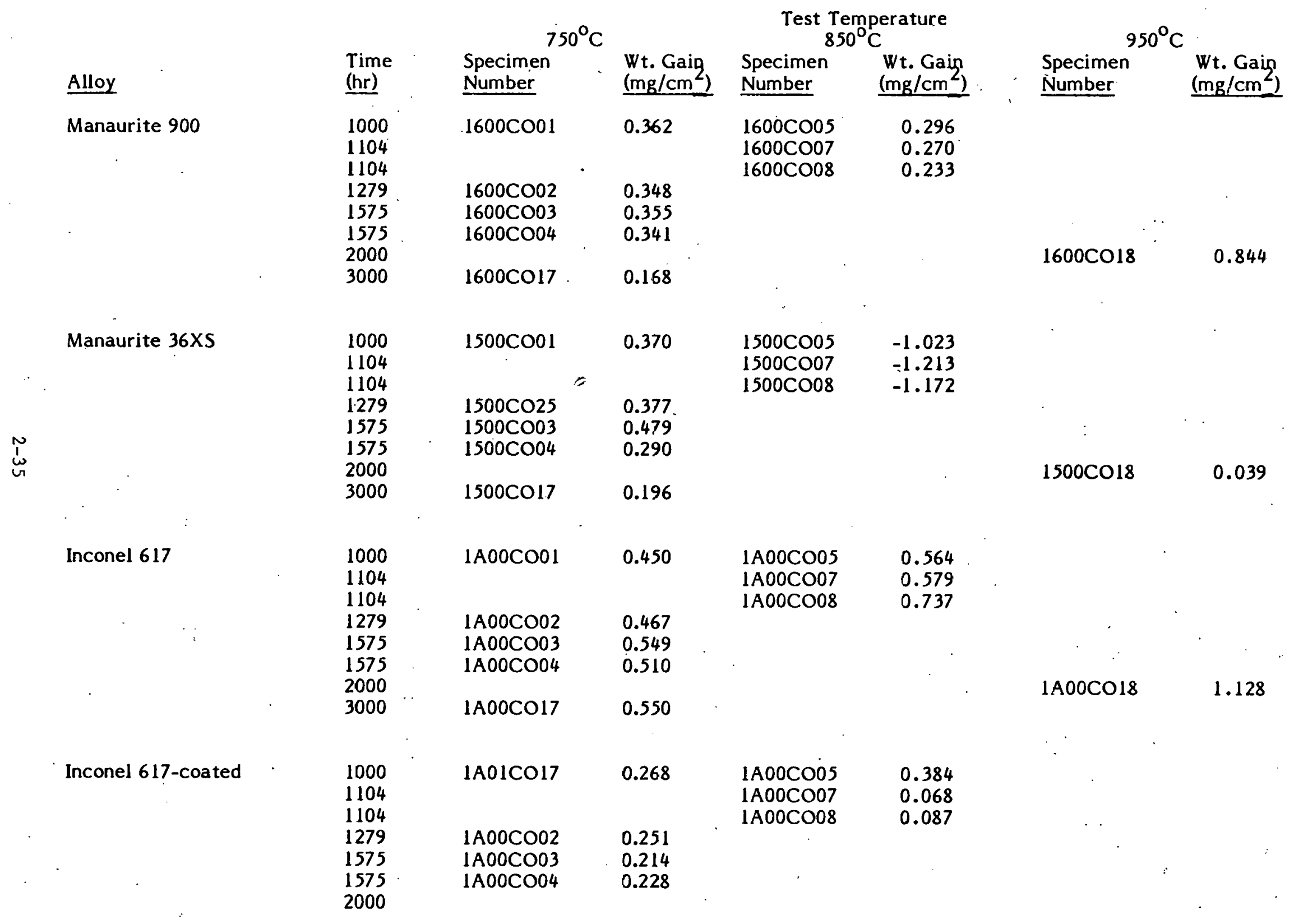


TABLE 11 (continued)

\begin{tabular}{|c|c|c|c|c|c|c|c|}
\hline \multirow[b]{2}{*}{ Alloy } & \multirow[b]{2}{*}{$\begin{array}{l}\text { Time } \\
\underline{\text { (hr) }}\end{array}$} & \multicolumn{2}{|c|}{$750^{\circ} \mathrm{C}$} & \multicolumn{2}{|c|}{$\begin{array}{l}\text { Test Temperature } \\
850^{\circ} \mathrm{C}\end{array}$} & \multicolumn{2}{|c|}{$950^{\circ} \mathrm{C}$} \\
\hline & & $\begin{array}{c}\text { Specimen } \\
\text { Number }\end{array}$ & $\begin{array}{l}\text { Wt. Gain } \\
\left(\mathrm{mg} / \mathrm{cm}^{2}\right)\end{array}$ & $\begin{array}{c}\text { Specimen } \\
\text { Number }\end{array}$ & $\begin{array}{l}\text { Wt. Gain } \\
\left(\mathrm{mg} / \mathrm{cm}^{2}\right)\end{array}$ & $\begin{array}{l}\text { Specimen } \\
\text { Number }\end{array}$ & $\begin{array}{l}\text { Wt. Gain } \\
\left(\mathrm{mg} / \mathrm{cm}^{2}\right)\end{array}$ \\
\hline Inconel $618 \mathrm{E}$ & $\begin{array}{l}1000 \\
1104 \\
1104 \\
1279 \\
1575 \\
1575 \\
2000 \\
3000\end{array}$ & $\begin{array}{l}\text { 1B00COO1 } \\
\text { 1B00CO02 } \\
1 \mathrm{~B} 00 \mathrm{CO} 03 \\
1 \mathrm{~B} 00 \mathrm{CO} 04 \\
1 \mathrm{~B} 00 \mathrm{CO} 17\end{array}$ & $\begin{array}{r}0.389 \\
- \\
0.467 \\
0.499 \\
0.516 \\
0.413\end{array}$ & $\begin{array}{l}1 \mathrm{~B} 00 \mathrm{CO} 05 \\
1 \mathrm{~B} 00 \mathrm{CO} 07 \\
1 \mathrm{~B} 00 \mathrm{CO} 08\end{array}$ & $\begin{array}{l}0.586 \\
0.549 \\
0.537\end{array}$ & $1 B 00 \mathrm{CO} 18$ & 0.688 \\
\hline Hastelloy $\mathrm{X}$ & $\begin{array}{l}1000 \\
1104 \\
1104 \\
1279 \\
1575 \\
1575 \\
2000\end{array}$ & $\begin{array}{l}1900 \mathrm{COO} 1 \\
1900 \mathrm{COO} 2 \\
1900 \mathrm{CO} 3 \\
1900 \mathrm{CO} 04\end{array}$ & $\begin{array}{l}0.501 \\
\\
0.409 \\
0.601 \\
0.387\end{array}$ & $\begin{array}{l}1900 C 005 \\
1900 C 007 \\
1900 C 008\end{array}$ & $\begin{array}{l}0.664 \\
1.228 \\
0.414\end{array}$ & $1900 C 018$ & 0.899 \\
\hline & & & & - & & & \\
\hline Mo-Re 2 & $\begin{array}{l}1000 \\
1104 \\
1104 \\
1279 \\
1575 \\
1575 \\
2000 \\
3000\end{array}$ & $\begin{array}{l}1 \mathrm{COOCOO1} \\
1 \mathrm{C} 00 \mathrm{CO} 02 \\
1 \mathrm{C} 00 \mathrm{CO} 03 \\
1 \mathrm{C} 00 \mathrm{CO} 04 \\
1 \mathrm{C} 00 \mathrm{CO} 17\end{array}$ & $\begin{array}{l}0.384 \\
\\
0.408 \\
0.469 \\
0.471 \\
-0.330\end{array}$ & $\begin{array}{l}1 \mathrm{C} 00 \mathrm{CO} 05 \\
1 \mathrm{C} 00 \mathrm{CO} 07 \\
1 \mathrm{C} 00 \mathrm{CO} 08\end{array}$ & $\begin{array}{l}0.700 \\
0.948 \\
0.819\end{array}$ & $1 \mathrm{C} 00 \mathrm{CO} 18$ & 1.542 \\
\hline MA-956 & $\begin{array}{l}1000 \\
1104 \\
1104 \\
1279 \\
1575 \\
1575 \\
2000\end{array}$ & $\begin{array}{c}\text { ID00CO01 } \\
? \\
\text { 1D00CO02 } \\
\text { 1D00CO03 } \\
\text { ID00CO04 }\end{array}$ & $\begin{array}{l}0.238 \\
0.217 \\
---\end{array}$ & $\begin{array}{l}\text { ID00CO05 } \\
\text { 1D00CO07 } \\
\text { 1D00CO08 }\end{array}$ & $\begin{array}{l}0.253 \\
0.138 \\
0.058\end{array}$ & $1 \mathrm{D00C0} 18$ & 0.263 \\
\hline
\end{tabular}


The $750^{\circ} \mathrm{C}$ data for the wrought iron-base alloys (Figure 4) indicate a sizeable weight gain for Incoloy alloy 807. The other four alloys and the single coated alloy generally fail in a band between $0.25-0.75 \mathrm{mg} / \mathrm{cm}^{2}$ weight gain. The coating appears to have reduced weight gain; after about 1,600 hour exposure, Alloy $800 \mathrm{H}$ (uncoated) had gained about twice the weight of the coated modification.

Somewhat similar results are in evidence for the wrought nickel-base materials (Figure 5) where the weight gain is between $0.2-0.6 \mathrm{mg} / \mathrm{cm}^{2}$. Again, the coated material gained weight at a slower rate than the uncoated alloy.

Distinct evidence of spallation was seen for at least two of the centrifugally cast alloys, HK-40 and Mo-Re 2, as indicated by the plot shown in Figure 6. Both of these alloys revealed a negative weight change after 3,000 hours of exposure.

Low weight gains (between $0.20-0.35 \mathrm{mg} / \mathrm{cm}^{2}$ ) are. revealed by the oxide dispersion strengthened alloys, as shown by the plot in Figure 7.

Figure 8 and 9 compare the 3,000 hour results of weight change for Inconel 617 and three centrifugally cast alloys studied by both General Atomic Company (GA) (1) and GE. Inspection of these plots and the comparison plots of 1,000hour results in Reference 2 reveal somewhat larger differences in the results after the longer time exposure. It is of interest to note, however, that the welght change of Inconel 617 as determined by GE is usually greater than that reported by GA. This may be due to the somewhat different environments employed by the two laboratories or to variations in the chemistry of the different heats of Inconel 617 used by the two laboratories.

\subsubsection{Visual Examination of Aged Specimens}

In order to characterize the undamaged texture and color of the surface scale that developed during controlled-purity helium exposure, the NPH corrosion pins removed from $750^{\circ} \mathrm{C}$ test were visually examined. These results are summarized in Table 12. Screening creep specimens tested at $750^{\circ} \mathrm{C}$ and $850^{\circ} \mathrm{C}$ were also visually characterized just prior to or just after strain measurements after 3,000 hours stressed exposure. Visual examination of the $950^{\circ} \mathrm{C}$ exposed specimens was also carried out after 1,000 hour stressed exposure. This information is tabulated for reference in Tables 13, 14 and 15. 


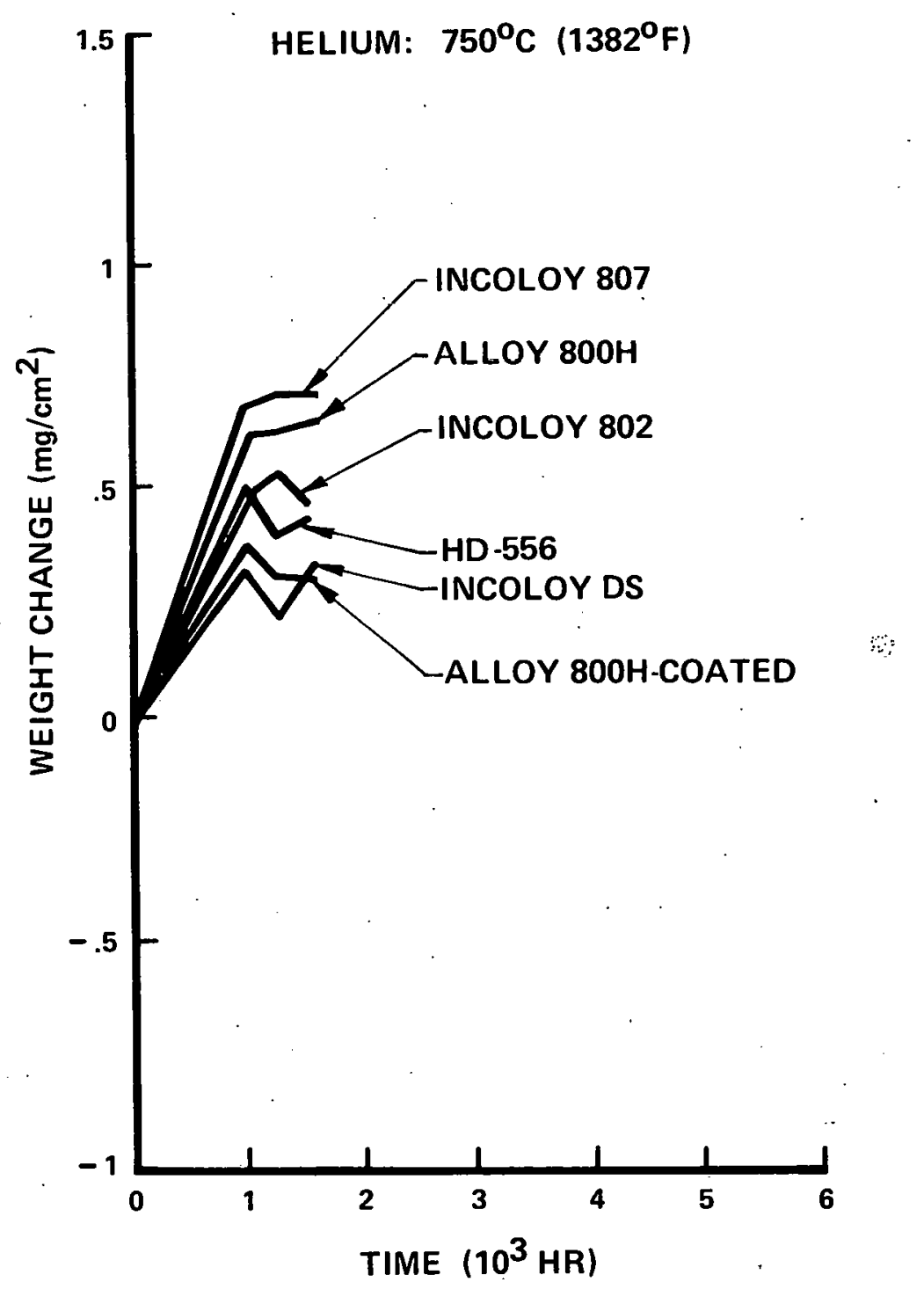

Figure 4. Weight Change of Wrought Iron-Base Alloys Aged Unstressed at $750^{\circ} \mathrm{C}$ in Controlled Purity Helium. 


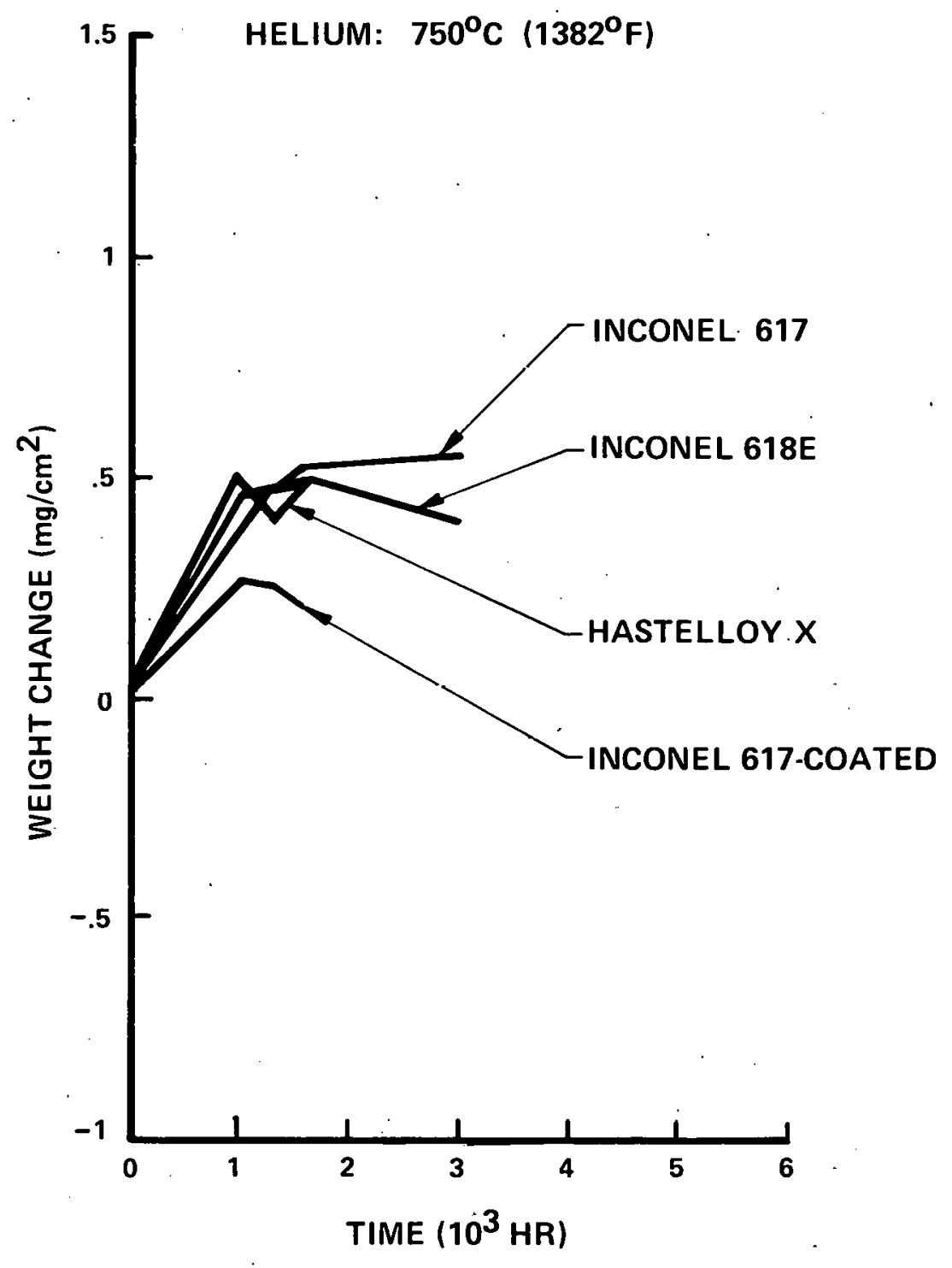

Figure 5: Weight Change of Wrought. Nickel-Base Alloys Aged Unstressed at $750^{\circ} \mathrm{C}$ in Controlled Purity Helium. 


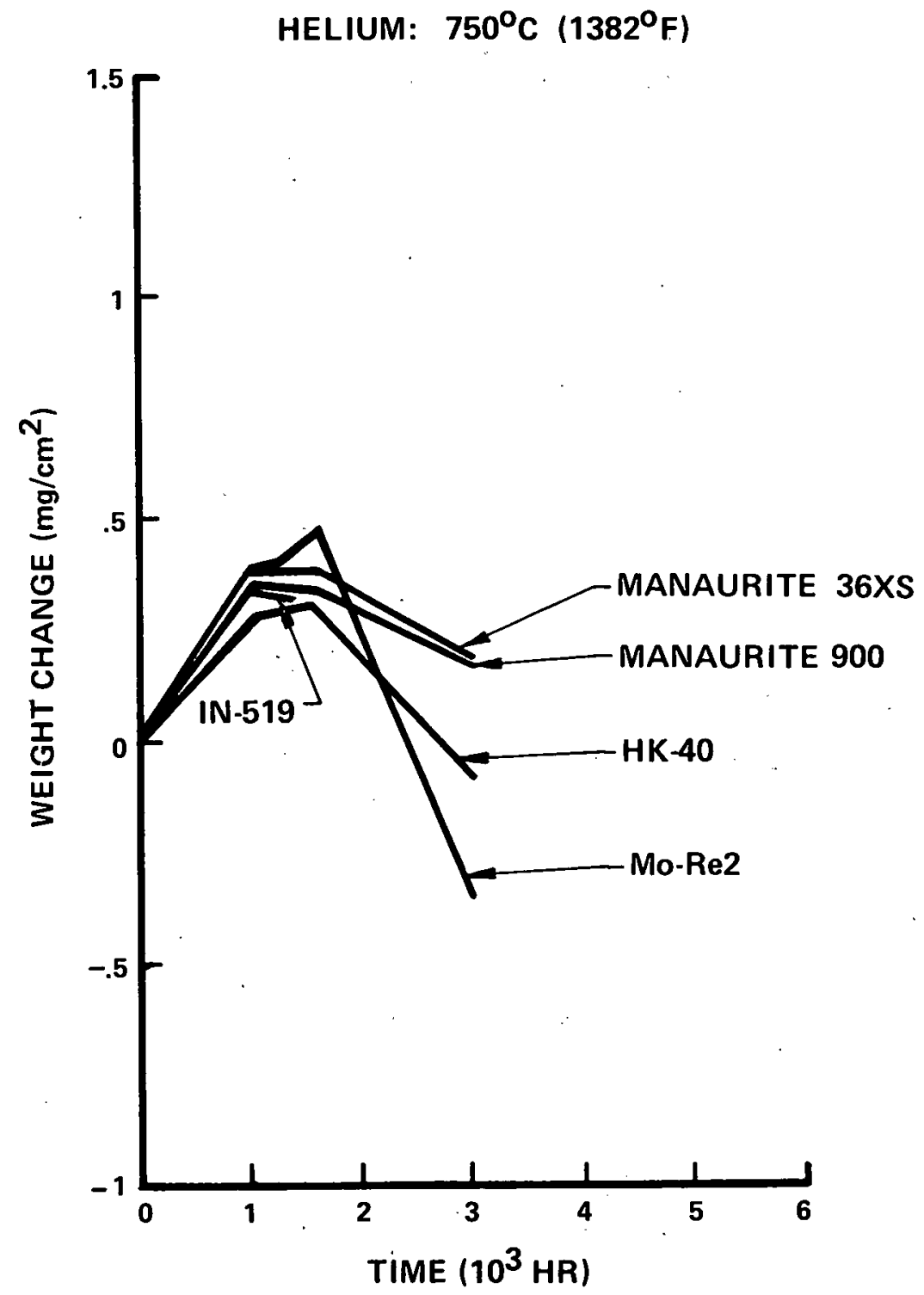

Figure 6. Weight Change of Centrifugally Cast Alloys Aged Unstressed at $750^{\circ} \mathrm{C}$ in Controlled Purity Helium. 


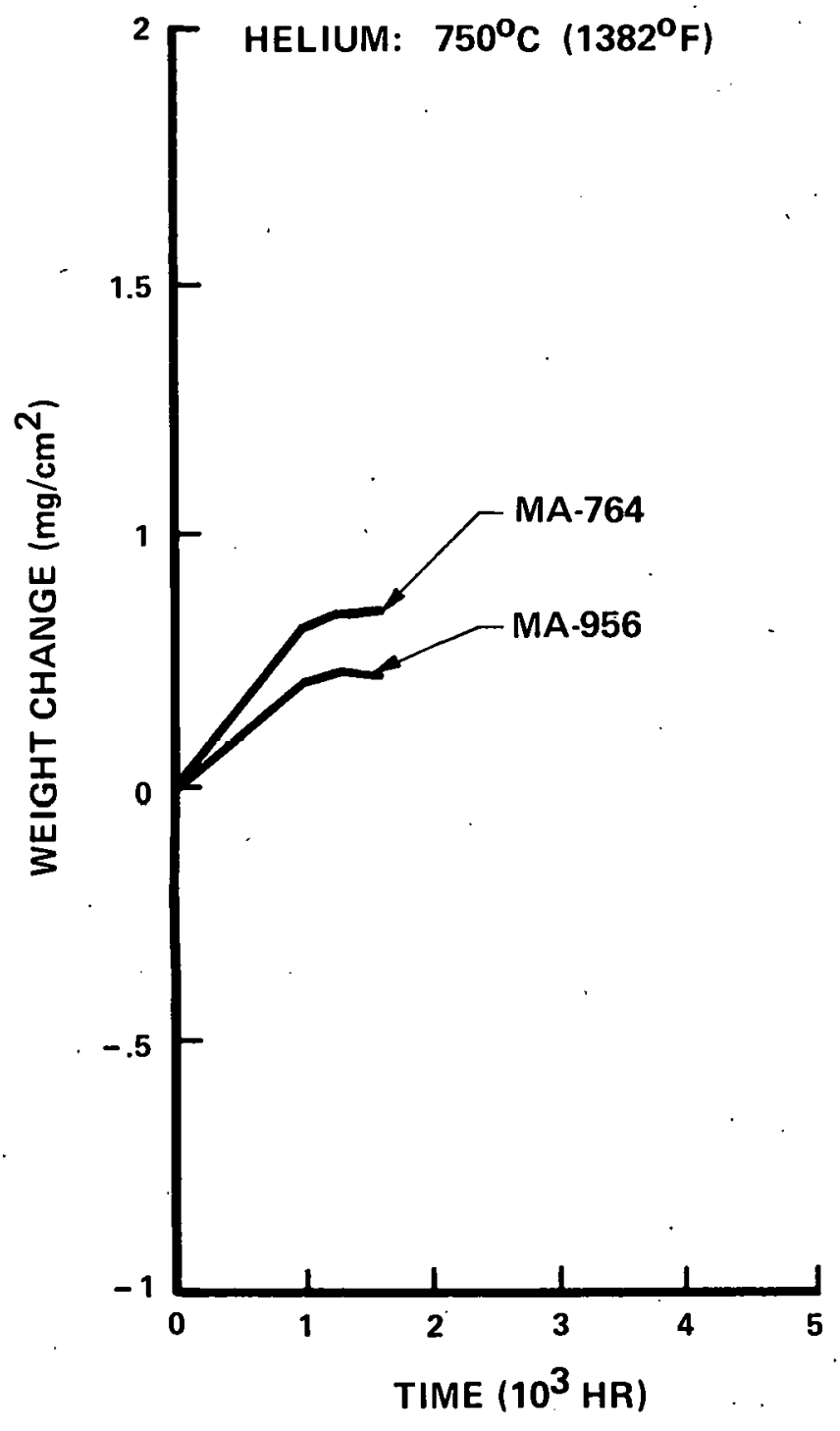

Figure 7. Weight Change of Oxide Dispersion Strengthened Alloys Aged Unstressed at $750^{\circ} \mathrm{C}$ in Controlled Purity Helium. 


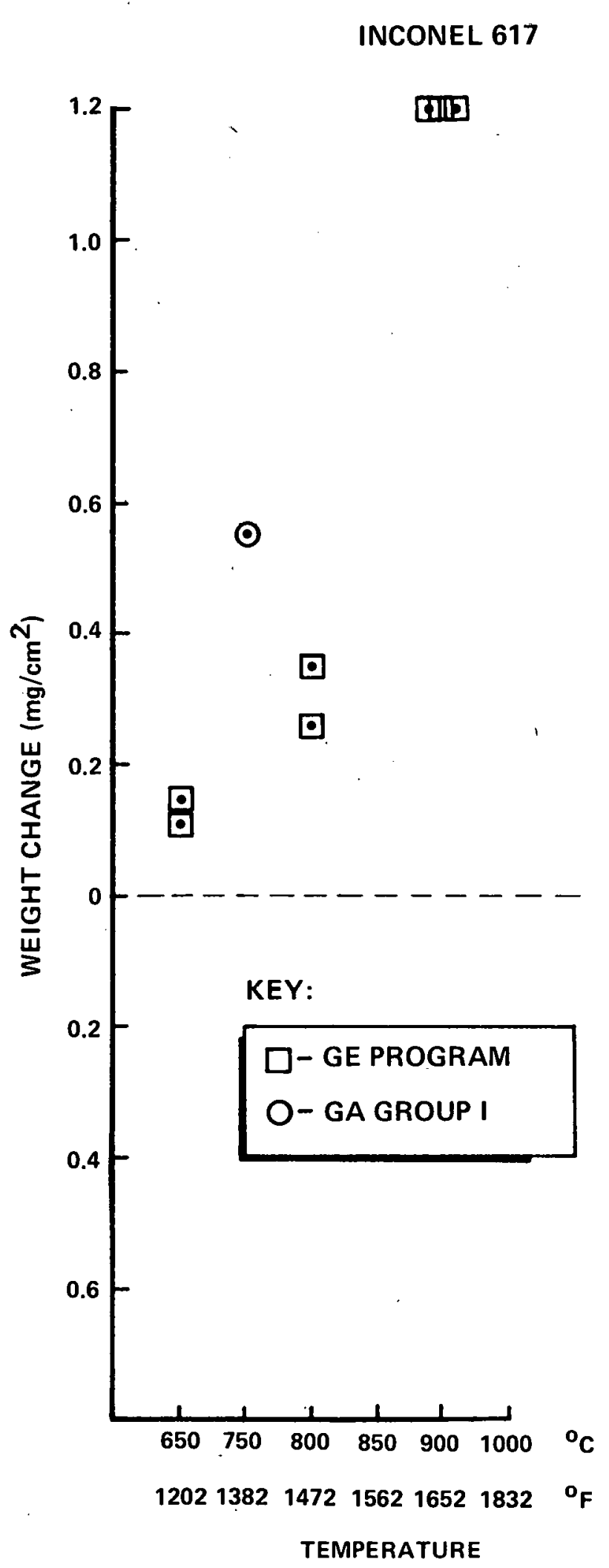

Figure 8. $3000 \mathrm{Hr}$. Weight Change Results for Inconel 617 Aged Unstressed in Controlled Purity Helium. 


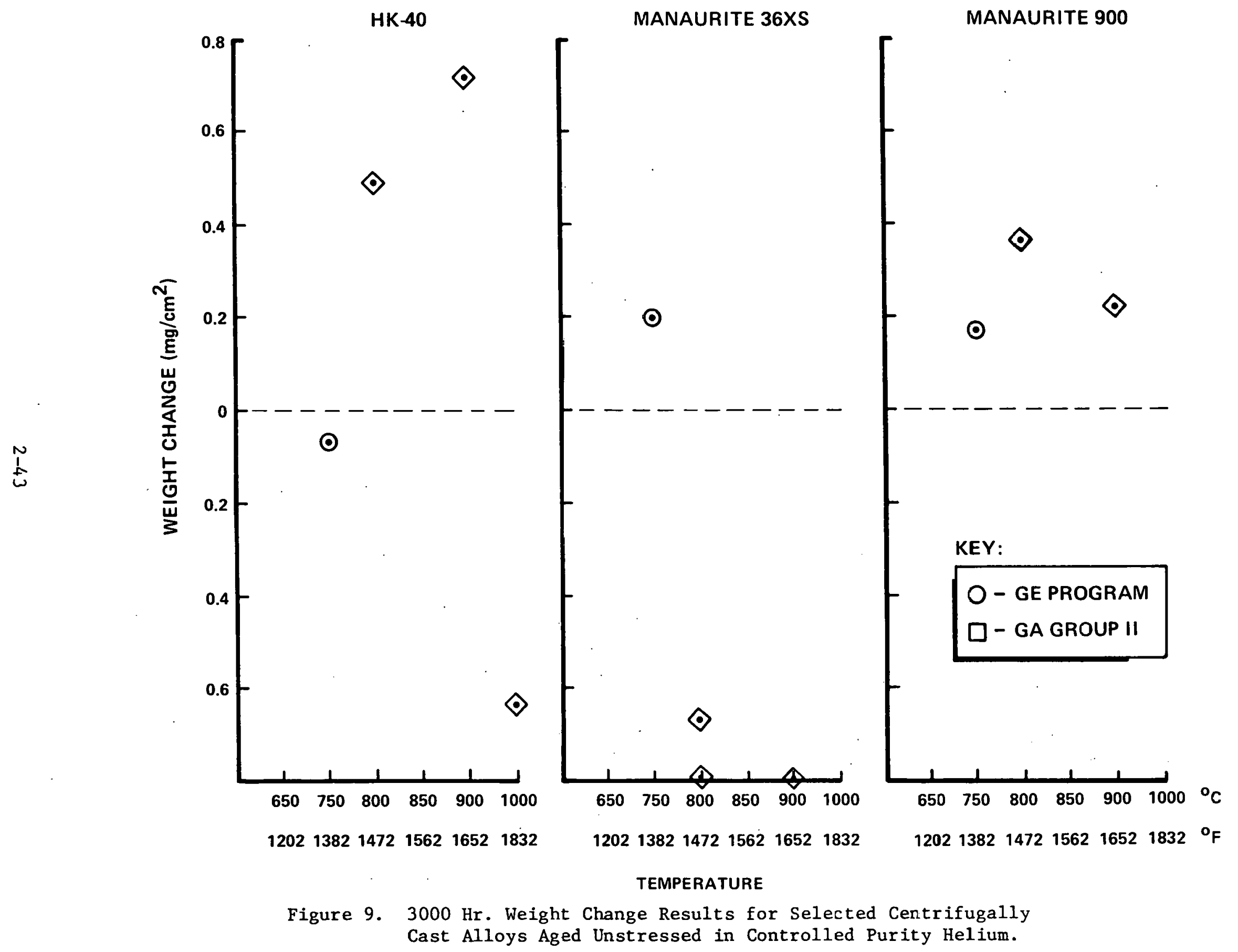


TABLE 12

RESULTS FROM VISUAL EXAMINATION OF STRUCTURAL STABILITY SPECIMENS AFT $\Xi R$ EXPOSURE TO $750 \mathrm{C}$ CONTROLLED-PURITY HELIUM

\begin{tabular}{|c|c|c|c|c|}
\hline Alloy & $\begin{array}{c}\text { Specimen } \\
\text { Nurnber }\end{array}$ & $\begin{array}{c}1000 \text { Hr Exposure } \\
\text { Surface Appearance }\end{array}$ & $\begin{array}{l}\text { Specimen } \\
\text { Number }\end{array}$ & $\begin{array}{c}3000 \mathrm{Hr} \text {-Exposure } \\
\text { Surface Appearance }\end{array}$ \\
\hline Alloy $800 \mathrm{H}$ & $1000 \mathrm{CO} 10$ & Jniform gray-purple & $1000 \mathrm{CO} 017$ & Uniform dark gray \\
\hline Alloy $800 \mathrm{H}$ & $1001 \mathrm{COO}$ & Iniform, matte gray-purple & $-\cdots$ & $-\cdots$ \\
\hline Incoloy 802 & $1100 \mathrm{COO} 1$ & Uniform dark gray-purple & $1100 \mathrm{CO} 17$ & Uniform dark gray \\
\hline Incoloy 807 & $1200 \mathrm{CO01}$ & $\begin{array}{l}\text { Medium gray-purple with area of } \\
\text {.ight gray (possible spalling) }\end{array}$ & $1200 C 017$ & Uniform dark gray \\
\hline Incoloy DS & $1300 \mathrm{CO} 01$ & $\begin{array}{l}\text { Gray-purple with specks of } \\
\text { !ight gray (spalling) }\end{array}$ & $1300 \mathrm{CO} 17$ & $\begin{array}{l}\text { Gray with specks of light gray } \\
\text { (possible spalling) }\end{array}$ \\
\hline HD-556 & $1400 \mathrm{COOI}$ & Uniform dark gray & $1400 \mathrm{CO} 017$ & Uniform dark gray \\
\hline HK-40 & $1700 \mathrm{COO}$ & $\begin{array}{l}\text { تray with specks of light gray } \\
\text { ispalling) }\end{array}$ & $1700 \mathrm{CO} 17$ & $\begin{array}{l}\text { Gray-green with specks of } \\
\text { light gray (spalling) }\end{array}$ \\
\hline IN-519 & $1800 \mathrm{COO} 1$ & $\begin{array}{l}\text { Iray-green with lustrous specks } \\
\text { or streaks (spalling) }\end{array}$ & $-\cdots$ & $-\cdots$ \\
\hline Manaurite 900 & $1600 \mathrm{COO} 1$ & $\begin{array}{l}\text { Gray with random light gray specks } \\
\text { !possible spalling) }\end{array}$ & $1600 \mathrm{CO} 17$ & $\begin{array}{l}\text { Purple-gray with random areas } \\
\text { of green (possible spalling) }\end{array}$ \\
\hline
\end{tabular}


TABLE 12 (Con't)

\begin{tabular}{|c|c|c|}
\hline Alloy & $\begin{array}{l}\text { Specimen } \\
\text { Number }\end{array}$ & $\begin{array}{c}1000 \mathrm{Hr} \text { Exposure } \\
\text { Surface Afpearance }\end{array}$ \\
\hline Manaurite $36 \mathrm{XS}$ & $1500 \mathrm{CO} 01$ & $\begin{array}{l}\text { Gray with random specks of } \\
\text { light gray (spalling) }\end{array}$ \\
\hline Inconel 617 & $1 \mathrm{~A} 00 \mathrm{CO} 01$ & Uniform gray-purple \\
\hline $\begin{array}{l}\text { Inconel } 617 \\
\text { Coated }\end{array}$ & $1 \mathrm{~A} 01 \mathrm{CO} 17$ & $\begin{array}{l}\text { Gray with areas o purple } \\
\text { and areas of greer. }\end{array}$ \\
\hline Inconel $618 \mathrm{E}$ & $1 \mathrm{~B} 00 \mathrm{CO} 01$ & Uniform semi-lustrous gray-purple \\
\hline Hastelloy X & $1900 \mathrm{CO} 1$ & Uniform medium gray \\
\hline Mo-Re 2 & $1 \mathrm{Co0COO1}$ & $\begin{array}{l}\text { Semi-lustrous gray with purple } \\
\text { green tint }\end{array}$ \\
\hline MA-956 & $1 \mathrm{D} 00 \mathrm{CO} 01$ & $\begin{array}{l}\text { Lustrous, areas of purple and } \\
\text { areas of green }\end{array}$ \\
\hline
\end{tabular}
Specimen
Number

$1500 \mathrm{CO} 17$

$1 \mathrm{~A} 00 \mathrm{CO} 17$

- . - -

1B00CO17

$1900 \mathrm{CO} 17$

$1 \mathrm{C} 00 \mathrm{CO} 17$

1D00CO17
$3000 \mathrm{Hr}$ Exposuré Surface Appearance

Purple-gray with random areas of green (spalling)

Very dark gray

Uniform semi-lustrous dark gray

Uniform dark gray

Gray with areas of purple and green (spalling)

Lustrous, purple-green 
RESULTS FROM VISUAL EXAMINATION OF SCREENING CREEP SPECIMENS AFTER EXPOSURE TO 75OC CONTROLLED-PURITY HELIUM

\begin{tabular}{|c|c|c|c|c|c|c|c|}
\hline Alloy & $\begin{array}{l}\text { Specimen } \\
\text { Number }\end{array}$ & String. & Pos. & $\begin{array}{l}\text { Stress } \\
(\mathrm{MPa})\end{array}$ & $1000-\mathrm{Hr}$ & $\begin{array}{l}\text { Time Exposed } \\
\text { 2000- } \mathrm{Hr}\end{array}$ & $3000-\mathrm{Hr}$ \\
\hline Incoloy 802 & $1100 \mathrm{SC} 01$ & 2 & 5 & 75.8 & dark gray & dark gray & dark gray \\
\hline HD -556 & $1400 S \mathrm{CO} 1$ & 2 & 6 & 75.8 & gray & dark gray & dark gray \\
\hline Inconel 617 & $1 \mathrm{AOOSC} 01$ & 2 & 7 & 75.8 & gray & dark gray & dark gray \\
\hline $\begin{array}{l}\text { Inconel } 617 \\
\text { coated }\end{array}$ & IAOISCOI & 2 & 8 & 75.8 & $\begin{array}{l}\text { light gray with purple } \\
\& \text { green undertones }\end{array}$ & $\begin{array}{l}\text { light gray with purple } \\
\text { \& green undertones }\end{array}$ & $\begin{array}{l}\text { light gray with purple } \\
\& \text { green undertones }\end{array}$ \\
\hline Inconel 617 & $1 \mathrm{~A} 00 \mathrm{SC} 02$ & 2 & 9 & 75.8 & gray & dark gray & dark gray \\
\hline IN-519. & $1800 \mathrm{SC} 30$ & 2 & 10 & 75.8 & $\begin{array}{l}\text { black with areas of } \\
\text { light gray (spalling) }\end{array}$ & & \\
\hline Mo-Re 2 & $1 \mathrm{Co0sC} 07$ & 2 & 11 & 75.8 & $\begin{array}{l}\text { gray with green } \\
\text { undertones }\end{array}$ & gray green & dark green gray \\
\hline Mo-Re 2 & $1 \mathrm{coosc} 01$ & 2 & 12 & 75.8 & $\begin{array}{l}\text { dark gray with green } \\
\text { undertones }\end{array}$ & gray green & dark green gray \\
\hline Alloy $800 \mathrm{H}$ & $1000 \mathrm{SC} 01$ & 3 & 1 & 48.3 & dark gray & dark gray & dark gray \\
\hline Alloy $800 \mathrm{H}$ & $1000 \mathrm{SC} 02$ & 3 & 2 & 48.3 & dark gray & dark gray & dark gray \\
\hline Incoloy 802 & $1100 \mathrm{SC} 03$ & 3 & 3 & 48.3 & gray purple & gray purple & dark gray \\
\hline Hastelloy X & $1900 \mathrm{SC} 03$ & 3 & 4 & 48.3 & dark gray & dark gray & dark gray \\
\hline $\begin{array}{l}\text { Inconel } 617 \\
\text { coated }\end{array}$ & $1 \mathrm{~A} 01 \mathrm{SCO} 2$ & 3 & 5 & 48.3 & $\begin{array}{l}\text { light gray with under- } \\
\text { tones of blue, gold } \& \\
\text { purple. }\end{array}$ & $\begin{array}{l}\text { gray with purple, green } \\
\text { blue undertones }\end{array}$ & $\begin{array}{l}\text { gray with purple } \\
\text { and blue tint }\end{array}$ \\
\hline
\end{tabular}


TABLE 13 (Con't)

\begin{tabular}{|c|c|c|c|c|c|c|c|}
\hline Alloy & $\begin{array}{l}\text { Specimen } \\
\text { Number }\end{array}$ & $\underline{\text { String. }}$ & Pos. & $\begin{array}{l}\text { Stress } \\
(\mathrm{MPa})\end{array}$ & $1000-\mathrm{Hr}$ & $\begin{array}{l}\text { Time Exposed } \\
2000-\mathrm{Hr}\end{array}$ & $3000-\mathrm{Hr}$ \\
\hline Manaurite $36 \times S$ & $1500 \mathrm{SC} 01$ & 3 & 6 & 48.3 & $\begin{array}{l}\text { gray with light gray } \\
\text { specks (possible } \\
\text { spalling) }\end{array}$ & dark gray & dark gray \\
\hline Manaurite $36 \mathrm{XS}$ & $1500 \mathrm{SC} 02$ & 3 & 7 & 48.3 & $\begin{array}{l}\text { gray with undertones } \\
\text { of purple }\end{array}$ & medium gray & dark gray \\
\hline $\mathrm{HK}-40$ & $1700 \mathrm{SC} 03$ & 3 & 8 & 48.3 & $\begin{array}{l}\text { med. gray with specks } \\
\text { of light gray (possible } \\
\text { spalling) }\end{array}$ & $\begin{array}{l}\text { gray with area of } \\
\text { green (possible } \\
\text { spalling) }\end{array}$ & $\begin{array}{l}\text { dark gray with areas } \\
\text { of gray (possible } \\
\text { spalling) }\end{array}$ \\
\hline $\mathrm{HK}-40$ & $1700 S_{C} 04$ & 3 & 9 & 48.3 & $\begin{array}{l}\text { gray with areas of } \\
\text { light gray }\end{array}$ & $\begin{array}{l}\text { dark gray with areas } \\
\text { of gray green }\end{array}$ & $\begin{array}{l}\text { dark gray with areas } \\
\text { of gray green }\end{array}$ \\
\hline IN-519. & $1800 \mathrm{SC} 03$ & 3 & 10 & 48.3 & $\begin{array}{l}\text { gray green (possible } \\
\text { areas of spalling) }\end{array}$ & $\begin{array}{l}\text { gray green (possible } \\
\text { areas of spalling) }\end{array}$ & $\begin{array}{l}\text { green with areas of } \\
\text { light gray (spalling) }\end{array}$ \\
\hline Mo-Re 2 & $1 \mathrm{CoOSC} 03$ & 3 & 11 & 48.3 & $\begin{array}{l}\text { dark gray with green } \\
\text { undertones }\end{array}$ & dark gray & $\begin{array}{l}\text { dark gray with green } \\
\text { undertones }\end{array}$ \\
\hline Incoloy 807 & $1200 \mathrm{SCO} 1$ & 5 & 5 & 62.0 & dark gray & dark gray & dark gray \\
\hline Incoloy 807 & $1200 \mathrm{SC} 02$ & 5 & 6 & 62.0 & medium gray & dark gray & dark gray \\
\hline HD-556 & $1400 \mathrm{SC} 02$ & 5 & 7 & 62.0 & medium gray & medium gray & dark gray \\
\hline Hastelloy $\mathrm{X}$ & $1900 \mathrm{SC} 01$ & 5 & 8 & 62.0 & dark gray & dark gray & dark gray \\
\hline Inconel 617 & $1 \mathrm{~A} 00 \mathrm{SC} 03$ & 5 & 9 & 62.0 & dark gray & dark gray & dark gray \\
\hline $\mathrm{HK}-40$ & $1700 \mathrm{SC} 01$ & 5 & 10 & 62.0 & $\begin{array}{l}\text { gray-green with areas } \\
\text { of light gray-green }\end{array}$ & $\begin{array}{l}\text { gray-green with areas } \\
\text { of light gray-green }\end{array}$ & $\begin{array}{l}\text { gray-green with areas } \\
\text { of light gray-green }\end{array}$ \\
\hline
\end{tabular}


TABLE 13. (Con't)

\begin{tabular}{|c|c|c|c|c|c|c|c|}
\hline Alloy & $\begin{array}{l}\text { Specimen } \\
\text { Number }\end{array}$ & String. & Pos. & $\begin{array}{l}\text { Stress } \\
(\mathrm{MPa})\end{array}$ & $1000-\mathrm{Hr}$ & $\begin{array}{l}\text { Time Exposed } \\
\underline{2000+\mathrm{Hr}}\end{array}$ & $3000-\mathrm{Hr}$ \\
\hline $\mathrm{HK}-40$ & $1700 \mathrm{SC} 02$ & 5 & 11 & 62.0 & light gray-green & light gray-green & $\begin{array}{l}\text { light gray-green with } \\
\text { areas of green }\end{array}$ \\
\hline $1 N-519$ & $1800 \mathrm{SC}^{2} 2$ & 5 & 12 & 62.0 & $\begin{array}{l}\text { gray-green with large } \\
\text { area light gray }\end{array}$ & $\begin{array}{l}\text { gray-green with areas } \\
\text { or specks of light gray }\end{array}$ & $\begin{array}{l}\text { green with areas or } \\
\text { specks of light gray } \\
\text { (possible spall) }\end{array}$ \\
\hline $\begin{array}{l}\text { Alloy } 800 \mathrm{H} \\
\text { coated }\end{array}$ & $10015 C 01$ & 6 & 1 & 20.7 & dark gray - purple & dark gray & dark gray \\
\hline $\begin{array}{l}\text { Alloy } 800 \mathrm{H} \\
\text { coated }\end{array}$ & $10015 C 02$ & 6 & 2 & 20.7 & dark gray - green & dark gray & dark gray \\
\hline Alloy $800 \mathrm{H}$ & $1000 \mathrm{SC} 03$ & 6 & 3 & 20.7 & dark gray & dark gray & dark gray \\
\hline $\begin{array}{l}\text { Alloy } 800 \mathrm{H} \\
\text { coated }\end{array}$ & $1001 S C 03$ & 6 & 4 & 20.7 & dark gray - purple & dark gray & dark gray \\
\hline Incoloy 807 & $1200 S_{C} 03$ & 6 & 5 & 20.7 & dark gray - purple & dark gray & dark gray \\
\hline Incoloy DS & $1300 \mathrm{SC} 01$ & 6 & 6 & 20.7 & gray & gray & gray \\
\hline Incoloy DS & $1300 \mathrm{SC} 02$ & 6 & 7 & 20.7 & gray & gray & gray \\
\hline HD-556 & $1400 \mathrm{SC} 03$ & 6 & 8 & 20.7 & dark gray & dark gray & dark gray \\
\hline Hastelloy X & $1900 \mathrm{SC} 02$ & 6 & 9 & 20.7 & dark gray & dark gray & dark gray \\
\hline $\begin{array}{l}\text { Inconel } 617 \\
\text { coated }\end{array}$ & $1 \mathrm{~A} 01 \mathrm{SC} 03$ & 6 & 10 & 20.7 & $\begin{array}{l}\text { light gray with purple } \\
\text { undertones }\end{array}$ & light gray & $\begin{array}{l}\text { light gray with purple } \\
\text { areas at shoulder }\end{array}$ \\
\hline Manaurite $36 \mathrm{XS}$ & $1500 \mathrm{SC} 03$ & 6 & 11 & 20.7 & light gray - green & light gray & light gray-green \\
\hline
\end{tabular}


TABLE 14

RESULTS FROM VISUAL EXAMINATION OF SCREENING CREEP SPECIMENS AFTER REMOVAL FROM 850C CONTROLLED-PURITY HELIUM EXPOSURE

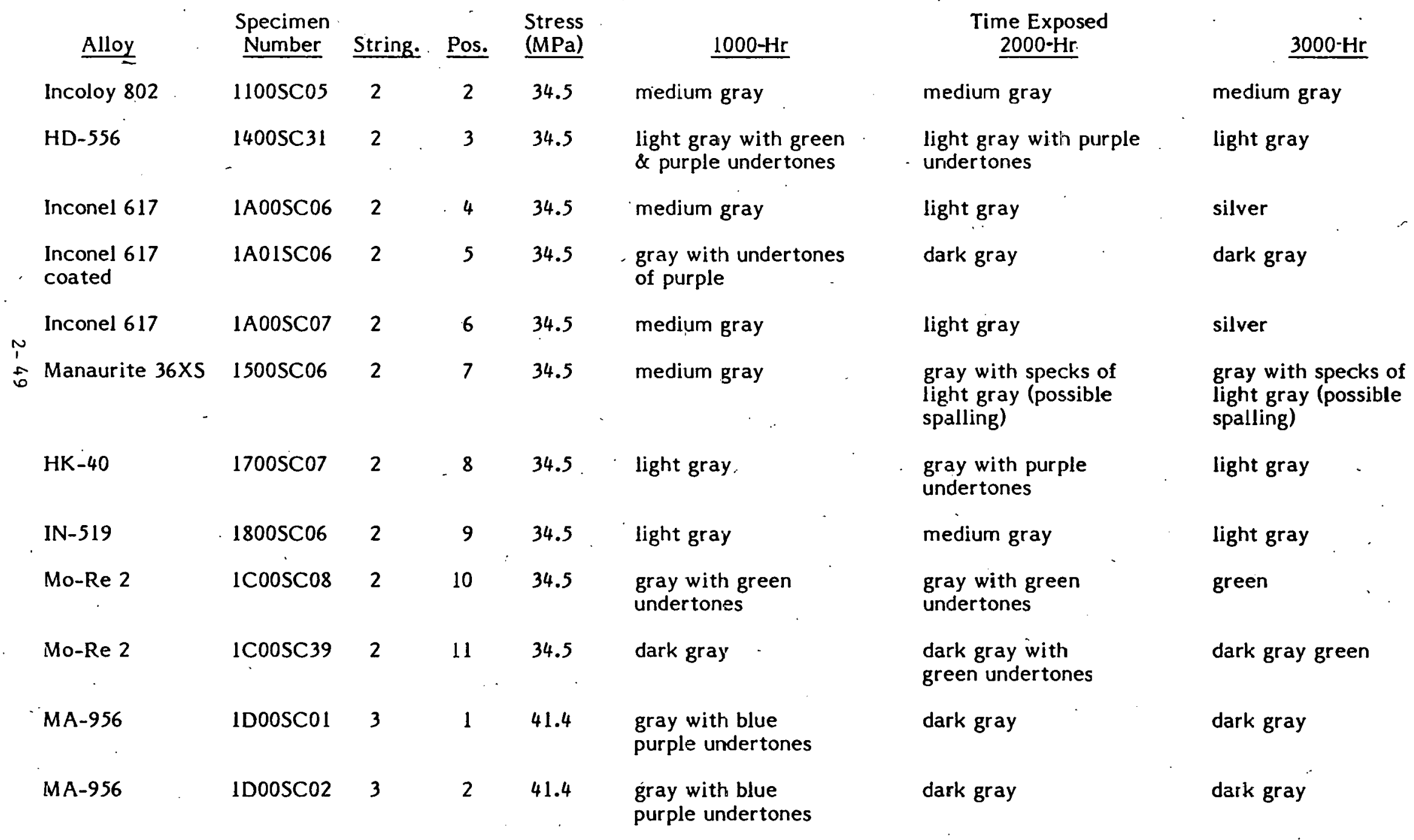


TABLE 14 (Con't)

\begin{tabular}{|c|c|c|c|c|c|c|c|}
\hline Alloy & $\begin{array}{l}\text { Specimen } \\
\text { Number }\end{array}$ & String. & Pos. & $\begin{array}{l}\text { Stress } \\
(\mathrm{MPa})\end{array}$ & $1000-\mathrm{Hr}$ & $\begin{array}{l}\text { Time Exposed } \\
\underline{2000-\mathrm{Hr}}\end{array}$ & $3000+\mathrm{Hr}$ \\
\hline Alloy $800 \mathrm{H}$ & $1000 \mathrm{SC} 05$ & 3 & 3 & 20.7 & medium gray & medium gray & medium gray \\
\hline Incoloy 802 & $1100 S \mathrm{SC} 07$ & 3 & 4 & 20.7 & medium gray & $\begin{array}{l}\text { gray with areas of } \\
\text { light gray }\end{array}$ & $\begin{array}{l}\text { gray with areas of } \\
\text { light gray }\end{array}$ \\
\hline Incoloy 807 & $12005 \mathrm{C} 06$ & 3 & 5 & 20.7 & medium gray & medium gray & medium gray \\
\hline HD-556 & $1400 \mathrm{SC} 07$ & 3 & 6 & 20.7 & light gray-metallic & light gray-metallic & light gray-metallic \\
\hline HD-556 & $1400 S \mathrm{C} 08$ & 3 & 7 & 20.7 & light gray-metallic & light gray-metallic & light gray-metallir \\
\hline Hastelloy $X$ & $1900 \mathrm{SC} 06$ & 3 & 8 & 20.7 & light gray & light gray & light gray \\
\hline $\begin{array}{l}\text { Inconel } 617 \\
\text { coated }\end{array}$ & $1 \mathrm{~A} 01 \mathrm{SC} 07$ & 3 & 9 & 20.7 & $\begin{array}{l}\text { light gray with blue } \\
\text { \& purple undertones }\end{array}$ & $\begin{array}{l}\text { gray with purple } \\
\text { undertones }\end{array}$ & dark gray \\
\hline Manaurite $36 \mathrm{XS}$ & $15005 \mathrm{C} 07$ & 3 & 10 & 20.7 & medium gray & medium gray & gray green \\
\hline $\mathrm{HK}-40$ & $1700 S \mathrm{C} 08$ & 3 & 11 & 20.7 & light gray & light gray & light gray-green \\
\hline MA-956 & 1D00SC03 & 5 & 1 & 55.2 & $\begin{array}{l}\text { medium gray with } \\
\text { purple green undertones }\end{array}$ & dark gray & dark gray \\
\hline Incoloy 807 & $1200 \mathrm{SC} 07$ & 5 & 5 & 27.6 & medium gray & medium gray & medium gray \\
\hline Hastelloy $X$ & $1900 \mathrm{SC} 07$ & 5 & 6 & 27.6 & light gray & light gray & light gray \\
\hline Inconel 617 & $1 \mathrm{~A} 00 \mathrm{SC} 08$ & 5 & 7 & 27.6 & light gray & light gray & silver \\
\hline
\end{tabular}


TABLE 14 (Con't)

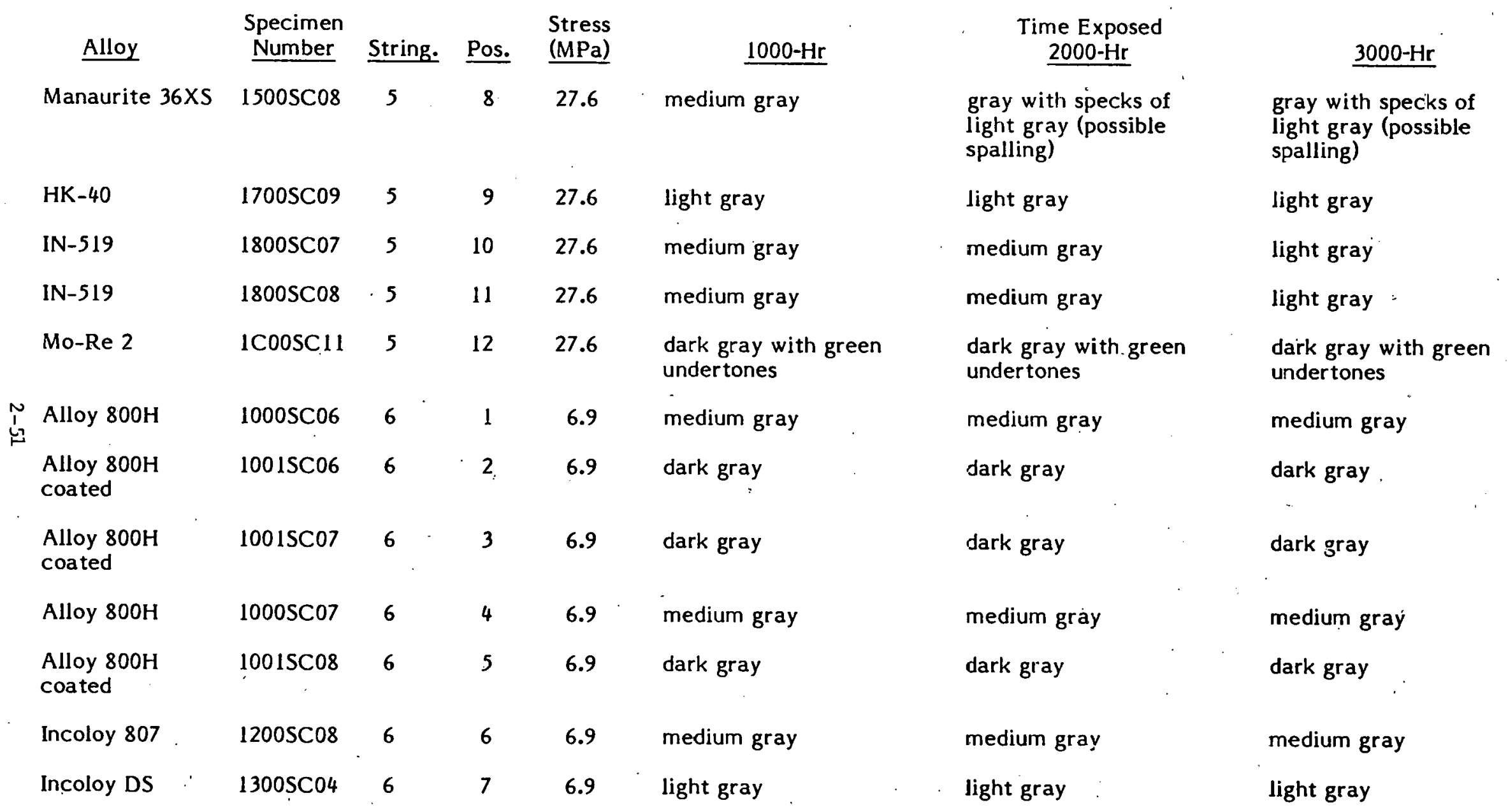


TABLE 14 (Con't)

\begin{tabular}{|c|c|c|c|c|c|c|c|}
\hline Alloy & $\begin{array}{l}\text { Specimen } \\
\text { Number }\end{array}$ & String. & Pos. & $\begin{array}{l}\text { Stress } \\
(\mathrm{MPa})\end{array}$ & $1000-\mathrm{Hr}$ & $\begin{array}{l}\text { Time Exposed } \\
2000-\mathrm{Hr}\end{array}$ & $3000+\mathrm{Hr}$ \\
\hline Incoloy DS & $1300 \mathrm{SC} 05$ & 6 & 8 & 6.9 & light gray & light gray & light gray \\
\hline Incoloy DS & $1300 \mathrm{SC} 06$ & 6 & 9 & 6.9 & light gray & light gray & light gray \\
\hline Hastelloy $\mathrm{X}$ & $1900 \mathrm{SC} 08$ & 6 & 10 & 6.9 & medium gray & light gray & light gray green \\
\hline $\begin{array}{l}\text { Inconel } 617 \\
\text { coated }\end{array}$ & $1 \mathrm{~A} 015 \mathrm{C} 08$ & 6 & 11 & 6.9 & $\begin{array}{l}\text { medium gray with areas } \\
\text { of dark gray }\end{array}$ & $\begin{array}{l}\text { gray with areas of } \\
\text { dark gray }\end{array}$ & dark gray \\
\hline
\end{tabular}




\section{TABLE 15}

RESULTS FROM VISUAL EXAMINATION OF SCREENING CREEP SPECIMENS AFTER REMOVAL FROM 950C CONTROLLED-PURITY HELIUM EXPOSURE

\begin{tabular}{|c|c|c|c|c|c|c|c|}
\hline Alloy & $\begin{array}{l}\text { Specimen } \\
\text { Number }\end{array}$ & String. & Pos. & $\begin{array}{l}\text { Stress } \\
(\mathrm{MPa})\end{array}$ & $1000 \cdot \mathrm{Hr}$ & $\begin{array}{l}\text { Time Exposed } \\
2000-\mathrm{Hr}\end{array}$ & $3000-\mathrm{Hr}$ \\
\hline MA-956 & 1D00SC06 & 1 & 7 & 48.3 & $\begin{array}{l}\text { dark gray with gold } \\
\text { undertones }\end{array}$ & & \\
\hline Incoloy 802 & $1100 S c 09$ & 2 & 2 & 13.8 & $\begin{array}{l}\text { gray with fine uniform } \\
\text { speckling }\end{array}$ & & \\
\hline Incoloy 807 & $1200 \mathrm{SC} 11$ & 2 & 3 & 13.8 & uniform gray & & \\
\hline Hastelloy X & $1900 \mathrm{SC} 10$ & 2 & 4 & 13.8 & $\begin{array}{l}\text { light gray with areas of } \\
\text { gold and blue }\end{array}$ & & \\
\hline $\begin{array}{l}\text { Inconel } 617 \\
\text { coated }\end{array}$ & 1A01SC11 & 2 & 5 & 13.8 & $\begin{array}{l}\text { dark gray with gold } \\
\text { tint at shoulders }\end{array}$ & & \\
\hline Inconel 617 & $1 \mathrm{AO0SC11}$ & 2 & 6 & 13.8 & uniform gray & & \\
\hline Manaurite 36 XS & $1500 \mathrm{SC} 11$ & 2 & 7 & 13.8. & light gray & & \\
\hline HK-40 & $1700 \mathrm{SC} 12$ & 2 & 8 & 13.8 & light gray & & \\
\hline IN-519 & $1800 \mathrm{SC} 11$ & 2 & 9 & 13.8 & light gray & & \\
\hline Mo-Re 2 & $1 \mathrm{CoOSC} 14$ & 2 & 10 & 13.8 & light gray green & & \\
\hline $\begin{array}{l}\text { Alloy } 800 \mathrm{H} \\
\text { coated }\end{array}$ & $1001 S C 11$ & 3 & 1 & 6.2 & black & & \\
\hline Alloy $800 \mathrm{H}$ & $1000 \mathrm{SC} 10$ & 3 & 2 & 6.2 & gray & & \\
\hline Incoloy 802 & $1100 \mathrm{SC} 10$ & 3 & 3 & 6.2 & gray & & 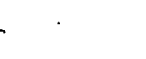 \\
\hline Incoloy 807 & $1200 \mathrm{SC} 12$ & 3 & 4 & 6.2 & gray & ' & - \\
\hline Incoloy DS & $1300 S C 09$ & 3 & 5 & 6.2 & light gray & " & \\
\hline
\end{tabular}


TABLE 15 (Con't)

\begin{tabular}{|c|c|c|c|c|c|c|c|}
\hline Alloy & $\begin{array}{l}\text { Specimen } \\
\text { Number }\end{array}$ & String: & Pos. & $\begin{array}{l}\text { Stress } \\
(\mathrm{MPa}) \\
\end{array}$ & $\underline{1000-\mathrm{Hr}}$ & $\begin{array}{l}\text { Time Exposed } \\
\underline{2000-\mathrm{Hr}}\end{array}$ & $3000-\mathrm{Hr}$ \\
\hline HD-556 & $1400 S C 11$ & 3 & 6 & 6.2 & $\begin{array}{l}\text { light gray with blue } \\
\text { tint }\end{array}$ & & \\
\hline Hastelloy X & $1900 \mathrm{SC} 11$ & 3 & 7 & 6.2 & $\begin{array}{l}\text { light gray with gold } \\
\text { tint }\end{array}$ & & \\
\hline Manaurite $36 \times 5$ & $1500 \mathrm{SC} 12$ & 3 & 8 & 6.2 & $\begin{array}{l}\text { light gray with gray } \\
\text { area (possible spall) }\end{array}$ & & $\cdot$ \\
\hline $\mathrm{HK}-40$ & $1700 \mathrm{SC} 13$ & 3 & 9 & 6.2 & light gray & & \\
\hline IN-519 & $1800 \mathrm{SC} 12$ & 3 & 10 & 6.2 & light gray & & \\
\hline MA-956 & $1 \mathrm{D} 00 \mathrm{SC} 07$ & 4 & 1 & 34.5 & $\begin{array}{l}\text { dark gray with gold } \\
\text { undertones }\end{array}$ & & \\
\hline I MA-956 & 1D00SC08 & 4 & 2 & 34.5 & $\begin{array}{l}\text { dark gray with gold } \\
\text { undertones }\end{array}$ & & \\
\hline HD-556 & $1400 \mathrm{SC} 12$ & 4 & 6 & 17.2 & $\begin{array}{l}\text { light gray with blue/ } \\
\text { gold tint }\end{array}$ & & \\
\hline Inconel 617 & $1 \mathrm{~A} 00 \mathrm{SC} 12$ & 4 & 7 & 17.2 & gray & & \\
\hline Inconel 617 & $1 \mathrm{~A} 00 \mathrm{SC} 13$ & 4 & 8 & 17.2 & gray & & \\
\hline IN-519 & $1800 \mathrm{SC} 13$ & 4 & 9 & 17.2 & light gray & & \\
\hline Mo-Re 2 & $1 \mathrm{C} 00 \mathrm{SC} 15$ & 4 & 10 & 17.2 & light gray & & \\
\hline Mo-Re 2 & $1 \operatorname{coosc} 16$ & 4 & 11 & 17.2 & light green gray & & \\
\hline Incoloy 802 & $1100 \mathrm{SC} 11$ & 5 & 10 & 8.6 & $\begin{array}{l}\text { gray with fine uniform } \\
\text { speckling }\end{array}$ & & \\
\hline HD-556 & $1400 \mathrm{SC} 13$ & 5 & 11 & 8.6 & gray & & \\
\hline
\end{tabular}


TABLE 15 (Con't)

\begin{tabular}{|c|c|c|c|c|c|c|c|}
\hline Alloy & $\begin{array}{l}\text { Specimen } \\
\text { Number }\end{array}$ & String. & Pos. & $\begin{array}{l}\text { Stress } \\
(\mathrm{MPa}) \\
\end{array}$ & $1000+\mathrm{Hr}$ & $\begin{array}{l}\text { Time Exposed } \\
\underline{2000-\mathrm{Hr}}\end{array}$ & $3000+\mathrm{Hr}$ \\
\hline $\begin{array}{l}\text { Inconel } 617 \\
\text { coated }\end{array}$ & $1 \mathrm{~A} 015 \mathrm{SC} 12$ & 5 & 12 & 8.6 & $\begin{array}{l}\text { dark gray with gold } \\
\text { tint at shoulders }\end{array}$ & & \\
\hline $\begin{array}{l}\text { Alloy } 800 \mathrm{H} \\
\text { coated }\end{array}$ & $10015 C 12$ & 6 & 4 & 0.69 & black & & \\
\hline Alloy $800 \mathrm{H}$ & $1000 \mathrm{SC} 11$ & 6 & 5 & 0.69 & light gray & : & \\
\hline $\begin{array}{l}\text { Alloy } 800 \mathrm{H} \\
\text { coated }\end{array}$ & $10015 C 13$ & 6 & 6 & 0.69 & black & . & \\
\hline Incoloy 807 & $1200 \mathrm{SC} 13$ & 6 & 7 & 0.69 & gray & & \\
\hline Incoloy DS & $1300 \mathrm{SC} 10$ & 6 & 8 & 0.69 & light gray & - & \\
\hline Incoloy DS & $1300 \mathrm{SC} 11$ & 6 & 9 & 0.69 & light gray & & \\
\hline Hastelloy X & $1900 \mathrm{SC} 12$ & 6 & 10 & 0.69 & $\begin{array}{l}\text { light gray with blue/ } \\
\text { gold tint }\end{array}$ & & \\
\hline $\begin{array}{l}\text { Incoloy } 617 \\
\text { coated }\end{array}$ & $1 A 01 S C 13$ & 6 & 11 & 0.69 & $\begin{array}{l}\text { black with gold } \\
\text { undertones }\end{array}$ & & \\
\hline
\end{tabular}


Generally, the wrought alloys revealed medium to dark gray scales with blue or purple undertones similar to the wrought alloys exposed in controlledpurity helium at $750^{\circ} \mathrm{C}$ for 1,000 hours. None of the wrought alloys showed evidence of spallation except Incoloy DS.

In contrast, the entire group of centrifugally cast alloys showed some evidence of scale spallation. This is somewhat similar to the $750^{\circ} \mathrm{C} / 1,000$ hour results, where each of the centrifugally cast alloys, except Mo-Re 2, exhibited evidence of spallation. In a few cases, large areas appeared to have spalled, especially for the two Manaurite alloys and Mo-Re 2. These observations are in agreement with the weight change results in that Mo-Re 2 and HK-40 revealed. negative weight changes indicating scale spallation.

The appearance of the 1ron-base ODS alloy was little changed from the 1,000 hour exposure and again looked rather lustrous.

\subsubsection{Metallographic Results}

Metallography has been completed on the six structural stability pins exposed for 3,000 hours at $750^{\circ} \mathrm{C}$. Specimens were prepared and examined as discussed in Reference 2. The results of the metallographic analysis, including comparative evaluations of the internal structure of as-received samples are presented in the following subsections. Reference is often made to the structure aged for 1,000 hours at $750^{\circ} \mathrm{C}$; these results can be found in Reference 2 .

The results of surface corrosion measurements and microstructural analysis for each of the six alloys are summarized in Table 16. The table includes measurements of scale thickness, oxide penetration, alloy depletion, and heavy carbide precipitation. In reviewing the photomicrographs showing the surface features of exposed samples, note that the white layer above the scale is electroplated nickel in all cases.

\subsubsection{Wrought Nickel-Base Austenitic Alloys}

\subsection{Incone1 617}

Representative optical photomicrographs of the internal microstructure of Inconel 617 after 3,000 hours exposure to controlled-purity helium at $750^{\circ} \mathrm{C}$ are shown in Figure 10. The microstructure was somewhat similar to that observed 
TABLE 16

SUMMARY OF SURFACE CORROSION MEASUREMENTS AND INTERNAL MICROSTRUCTIJRAL ANALYSIS FOR

ALLOYS AGED UNSTRESSED IN CONTROLLED-PURITY HELIUM FOR 3000 HOURS

Typical Corrosion Depth

( $\mu \mathrm{m}(\mathrm{in}))$

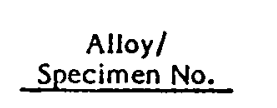

Inconel 617

Inconel 617

IAO0CO17

$750^{\circ} \mathrm{C}\left(1382^{\circ} \mathrm{F}\right)$

$\left(8 \times 10^{-3-3}-1 \times 10^{-4}\right)$

$\stackrel{9-11}{\left(3.5-4.3 \times 10^{-4}\right)}$

$20-24$
$\left(7.9-9.4 \times 10^{-4}\right.$

$\left(8 \times 10^{-3^{-3}}-1 \times 10^{-4}\right)$

$\left(4 \times 10^{-5}\right)$

$\left(4.7-6.3 \times 10^{-4}\right)$

As-Cast

HK-40

.

IIK-40
$1700 \mathrm{CO} 17$ $750^{\circ} \mathrm{C}\left(1382^{\circ} \mathrm{F}\right)$ $\left(8 \times 10^{-3^{-3}}-1 \times 10^{-5}\right)$
$48-60$
$\left(1.9-2.4 \times 10^{-3}\right)$

12-16

$\left(1.4-1.7 \times 10^{-3}\right)$

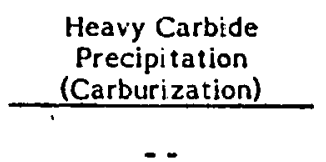

$-$

$\cdots$

$\left(3 \times 10^{-4}\right)$
Suininary of Internal Structur

Ni-rich Y-matrix (austenite) containing a mixture of coarse and fine carbides. The carbides were dispersed both intra- and intergranularly within the structure.

$\mathrm{Ni}$-rich Y-matrix (austenitc) containing a mixture of primary precipitated carbides dispersed both intra- and intergranularly on twin boundaries. Preferential precipitation of carbides along precipitation of carbides along
certain crystallographic directions was evident.

Ni-rich $\gamma$-matrix (austenite) containing a mixture of coarse and fine carbides dispersed both intraand in tergranularly.

Ni-rich $\gamma$-matrix (austenite)

containing a inixture of coarse and containing a mixture of coarse and and intergranularly.

Fe-rich $\gamma$-matrix (austenite) containing an austenite-carbide eutectic. The cutectic was dispersed at the dendrite boundaries or inter-dendritically as a lacelike or script-like network or as a grouping of blocky particles.

Constituents same as for as-cast condition except inicrostructure containi large arnounts of fine seconciary (presipitated) carbides in intradendritic regions. 
TABLE 16

Typical Corrosion Depth

$$
\text { ( } \mu \mathrm{m} \text { (in)) }
$$

Alloy/

Specimen No.

Manaurite 36XS
Condition
(Exposure

Temperature)

As-Cast

$750^{\circ} \mathrm{C}\left(1382^{\circ} \mathrm{F}\right)$

$36 \times 5$

1500 Co17

$\hat{1}$

Manaurite 900

As-Cast

Manaurite 900 $1600 \mathrm{SC} 16$

Mo-Re 2

$1700 \mathrm{CO} 17$

As-Cast

$750^{\circ} \mathrm{C}\left(1382^{\circ} \mathrm{F}\right)$
Scale

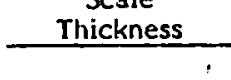
Oxidation

$-\cdot$

\begin{tabular}{c} 
Alloy \\
Depletion \\
\hline
\end{tabular}

$\left(8 \times 10^{\left.-5^{-3}-1 \times 10^{-4}\right)}\right.$

$\left(4 \times 10^{-5}\right)$

$\left(2.4-3.9 \times 10^{-4}\right.$

$\left(8 \times 10^{-5}\right)$

$5-7$
$\left(2-3 \times 10^{-4}\right)$ $\left(2-3 \times 10^{-4}\right)$
$6-10$

$3.9 \times 10^{-4}$

Heavy Carbide

Precipitation

(Carburization)

$10-14$

$\left(3.9 \times 5.5 \times 10^{-5}\right.$

$14-28$
$\left(5.5 \times 10^{-4}\right.$
$\left.1.1 \times 10^{-3}\right)$

$-\cdot$

$15-18$

$\stackrel{5-7}{\left(2-3 \times 10^{-4}\right)}$

$\left(5.9-7.1 \times 10^{-4}\right.$
Summary of

Fe-rich $\gamma$-matrix (austenite) containing an almost continuous austenite-carbide eutectic at the dendrite boundaries and in interdendritic regions. The eutectic carbides generally appear as a lace-like network or as groupings of blocky carbide particles.

Constituents same as for as-cast condition except inicrostructure contains copious amounts of carbides precipitated mainly in the intradendritic reglons near eutectic carbides. More abundant and solnewhat larger acicular particles relative to $750^{\circ} \mathrm{C} / 1000 \mathrm{hrs}$ structure.

Fe-rich $\gamma$-matrix (austenite)

containing an austenite carbide eutectic. The eutectic carbides, present at dendrite boundaries and interdendritically, generally appear as a lace-like network.

Constituents same as for as-casi condition except microstructure contains fine secondary (precipitated) carbides in inter and intradentritic regions.

Ni-rich $\gamma$-matrix (austenite) containing all austenite carbide eutectic at the dendrite boundaries and in interdendritic regions.

Eutectic carbides generally appeared as lace-like or script-type carbides.

Constituents same as for as-cast condition except microstruclure contains a large amount of secondary carbides. Coalescence of eutectic carbide to a grouping of globular carbide particles. 
after 1,000 hours aging at $750^{\circ} \mathrm{C}$ and consisted of a mixture of primary carbides like those observed in the as-received alloy, and intermediate-to-fine precipitated carbides appearing both intra- and intergranularly and on twin boundaries. Again, precipitation along certain crystallographic directions was evident; however, the grain boundaries revealed an almost continuous film of intermediate-sized globular particles rather than the finer carbides observed after 1,000 -hour exposure at $750^{\circ} \mathrm{C}$.

The surface microstructure of Inconel 617 after 3,000 hours at $750^{\circ} \mathrm{C}$ is shown in Figure 11 and was characterized by a 2-3 $\mu \mathrm{m}$ thick, continuous gray scale containing widely scattered, small white particles. Beneath the scale, gray finger-like particles characterized a 9-11 $\mu \mathrm{m}$ deep internally oxidized zone. An alloy depleted zone was observed to a depth of 20-24 $\mu \mathrm{m}$. The most significant near-surface microstructural difference between the $750^{\circ} \mathrm{C} 1,000$-hour and $3,000-$ hour aged samples was the increase in twin boundary, intra- and intergranular carbide precipitation (as a result of carburization) observed in the latter specimen (Figure $10 \mathrm{~b}$ ) to a depth of $48-60 \mu \mathrm{m}$.

\section{$\underline{2.6 .3 .1 .2 ~ I n c o n e l ~} 618 \mathrm{E}$}

Typical optical photomicrographs showing the internal microstructure of Inconel $618 \mathrm{E}$ after 3,000-hour/exposure to controlled-purity helium at $750^{\circ} \mathrm{C}$ are presented in Figure 12. As with Inconel 617, the internal microstructure of the 3,000 hour aged Inconel $618 \mathrm{E}$ sample was essentially equivalent to the 1,000-hour aged sample, but with perhaps somewhat finer carbide precipitation. Constituents are essentially the same as for the Inconel $617^{\circ}$ alloy.

The surface condition of Inconel 618E (shown in Figure 13) was rather similar to that observed for Inconel 617, except the extent of internal oxidation was minimal (approximately $1 \mu \mathrm{m}$ deep), due to the alloy's extremely low aluminum content. Scale thickness was 2-3 $\mu \mathrm{m}$, and an alloy depleted zone extended to a depth of 12-16 $\mu \mathrm{m}$. Below the depleted zone, a high density of precipitated carbides was evident to a depth of 36-44 $\mu \mathrm{m}$. Additionally, although not readily apparent in Figure 13, the alloy depleted zone appeared to be composed of fine (roughly $10 \mu \mathrm{m}$ diameter) recrystallized grains. This effect was also observed after 1,000 -hour aging at both $750^{\circ} \mathrm{C}$ and $850^{\circ} \mathrm{C}$. After prolonged etching and microscopic examination, a similar situation is believed to exist for the Inconel 617 alloy depleted (denuded) zone. Unfortunately evidence of recrystallization is partially masked by the presence of a significant amount of internal oxidation. 


\subsubsection{Centrifugally Cast Alloys}

\subsection{HK-40}

The photomicrographs shown in Figure 14 are typical of the microstructure of HK-40 after 3,000 hours aging in controlled-purity helium at $750^{\circ} \mathrm{C}$. This exposure resulted in an abundant degree of carbide precipitation. For the most part, the carbides were evident as fine-to-intermediate, roughly spherical particles; however, precipitates with a Widmanstatten structure (presumably carbides) were also observed throughout the sample (Figure 14). This type of precipitate has been previously observed (3) (at least in the near surface region) in samples of $\mathrm{HK}-40$ which had been thermally exposed in controlled-purity helium. Additionally, in contrast to the $750^{\circ} \mathrm{C} / 1,000$-hour exposed specimen, evidence of coring was no longer apparent after 3,000-hour aging.

The surface features of $\mathrm{HK}-40$, shown in Figure 15, were fairly similar to those observed after aging for 1,000 hours at $750^{\circ} \mathrm{C}$. As before, the scale (approximately 2-3 $\mu \mathrm{m}$ thick), appeared to be noncontinuous or spalled. Evidence of internal oxidation was not apparent; however, the scale occasionally appeared to intrude into the base metal. Below the surface scale, an alloy depleted region extended to a depth of $8 \mu \mathrm{m}$. Surprisingly, evidence of increased nearsurface carbide precipitation was not apparent.

\subsection{Manaurite $36 \mathrm{XS}$}

The internal microstructure of Manaurite 36Xs after 3,000-hour aging in controlled-purity helium at $750^{\circ} \mathrm{C}$ is typified by the optical photomicrographs shown in Figure 16 and 17 . The microstructure revealed an abundant degree of secondary carbide precipitation, mainly in the intradendritic regions near the eutectic carbides. Some coarsening of the globular eutectic carbide structure was also evident when compared with the alloy aged at $750^{\circ} \mathrm{C}$ for 1,000 hours. Additionally, the acicular particles first observed after 1,000-hour aging were now abundant and somewhat larger. These needle-like particles, preferentially precipitated along certain crystallographic directions, are typical of the Sigma phase.

The surface of Manaurite $36 \mathrm{XS}$ was characterized by a partially spalled, $23 \mu \mathrm{m}$ thick scale which contained fine white particulates (probably carbides). Little evidence of internal oxidation was observed; however, a light etching alloy depleted zone was observed to a depth of 6-10 $\mu \mathrm{m}$. In this alloy, evidence 
of carburization was manifested by increased fine-to-coarse intradendritic carbide penetration to a depth of between 10-14 $\mu \mathrm{m}$.

\subsection{Manaurite 900}

The photomicrographs shown in Figure 18 are representative of the microstructures of Manaurite 900 after 3,000-hour aging in controlled-purity helium at $750^{\circ} \mathrm{C}$. As with the other centrifugally cast alloys, exposure at $750^{\circ} \mathrm{C}$ resulted in the precipitation of fine carbide particles both inter-and intradendritically. In this case, however, microstructures were essentially equivalent after both the 1,000-hour and 3,000-hour exposures. It is of interest to note (Figure 18) that the degree of secondary carbide precipitation is significantly reduced in Manaurite 900 relative to the other centrifugally cast alloys since the carbon level is $1 / 2$ to $1 / 4$ that of the other alloys in this class.

The surface of Manaurite 900 exhibited a $2 \mu \mathrm{m}$ thick gray scale (Figure 19) above an 8-10 $\mu \mathrm{m}$ deep denuded zone. The near surface region also revealed evidence of carburization in the form of fine-to-intermediate sized precipitated carbides. Some preferentially oriented carbide precipitation was also evident, as shown in Figure 19.

\section{$\underline{2.6 .3 .2 .4 \quad M n-\operatorname{Re} 2}$}

Typlcal optical photomicrographs showing the internal microstructure of Mo-Re 2 after 3,000-hour exposure to controlled purity helium at $750^{\circ} \mathrm{C}$ are shown in Figure 20.

Copious amounts of secondary carbide precipitation were revealed mainly within the intradendritic regions. This feature is quite similar to that observed in the $750^{\circ} \mathrm{C} / 1,000$-hour exposed specimen. However, the lace-11ke or script-type austenite-carbide eutectic which was evident after 1,000 hour aging at $750^{\circ} \mathrm{C}$ (as well as in the as-cast material) has coalesced after an additional 2,000-hour exposure and transformed to a grouping of discrete, intermediate-sized globular carbide particles.

After 3,000-hour exposure at $750^{\circ} \mathrm{C}$, the surface of the alloy was covered by a discontinuous or partially spalled triple-layered scale about 5-7 $\mu \mathrm{m}$ thick, as shown in Figure 21. The layered scale consisted of a gray outer surface 
layer, a secondary white layer, and a fairly continuous tertiary gray layer that contained fine white particles in some areas. As illustrated by the photomicrographs in.Figure 21, significant portions of the outer two layers were discontinuous or spalled. Beneath the scale, a 5-7 $\mu \mathrm{m}$ deep, sparsely populated oxidized zone was evident in an alluy depleted region of similar depth. Additionally, a high density region of carbide precipitation was evident to a depth of 15-18 $\mu \mathrm{m}$.

\subsubsection{Summary of Metallographic Results.}

In reviewing the bulk microstructural features of the six alloys discussed above, it has become clear that, although similaritles exist, thermal aging effects appear somewhat more pronounced after the $750^{\circ} \mathrm{C} / 3,000$ hour-exposure relative to that observed in comparable samples aged for 1,000 hours. Generally, the degree of both intragranular and intradendritic (secondary) carbide precipitation was greater after the longer aging time. Grain boundary carbides were also somewhat larger, globular and semi-continuous. Additionally, the acicular particles (typical of the Sigma phase) observed in the centrifugally cast alloy, Manaurite $36 \mathrm{XS}$, were more abundant and somewhat larger.

Interestingly, the $850^{\circ} \mathrm{C} / 1,000$-hour/metallographic findings (reported in the last Quarterly Report) were slightly less akin to the results discussed in the preceding paragraphs. The most obvious difference was the notable absence of the acicular precipitate in the $850^{\circ} \mathrm{C} / 1,000$-hour aged sample of Manaurite $36 \mathrm{XS}$. Other less obvious disparities were manifest in the degree of coalescence of the carbides (both intergranular and eutectic) which had taken place in the centrifugally cast alloys, with coalescence being greater at the higher aging temperature. Also, grain boundary carblut growth was snmewhat more advanced after $850^{\circ} \mathrm{C}$ exposure.

A summary of the corrosion measurements for the six alloys discussed above is given in Table 1.7. Gas/metal interactions were quite evident and usually in excess of that observed after $750^{\circ} \mathrm{C} / 1,000$-hour aging. Aside from increased thickness, surface scales were generally more complex and, in one case (Mo-Re 2), a triple-layered, partially spalled scale was evident. Surface oxidation was also sporadically noted, but was present to a greater extent in the high aluminum content Inconel 617. An alloy depleted (or light-etching) 
TABLE 17

SUMMARY OF CORROSION MEASUREMENTS FOR SELECTED ALLOYS AGED UNSTRESSED IN CONTROLLED-PURITY HELIUM

Typical Corrosion Depths

( $\mu \mathrm{m})$

Exposure Exposure

Temp Time Scale Internal

Alloy

(hours) Thickness

Depletion

Carbur-

Avg. Wt.

Alloy

$\underline{\left({ }^{\circ} \mathrm{C}\right)}$

Oxidation

ization

Change

\begin{tabular}{|c|c|c|c|c|c|c|c|}
\hline Inconel 617 & $\begin{array}{l}750 \\
750 \\
850\end{array}$ & $\begin{array}{l}1,000 \\
3,000 \\
1,000\end{array}$ & $\begin{array}{c}1 \\
2-3 \\
2-5\end{array}$ & $\begin{array}{c}4 \\
9-11 \\
5-14\end{array}$ & $\begin{array}{l}6-12 \\
20-24 \\
\sim 10\end{array}$ & $\begin{array}{c}-- \\
48-60 \\
--\end{array}$ & $\begin{array}{l}+0.450 \\
+0.550 \\
+0.658\end{array}$ \\
\hline Inconel $618 \mathrm{E}$ & $\begin{array}{l}750 \\
750 \\
850\end{array}$ & $\begin{array}{l}1,000 \\
3,000 \\
1,000\end{array}$ & $\begin{array}{c}2 \\
2-3 \\
2-7\end{array}$ & ${ }^{--}$ & $\begin{array}{c}6-14 \\
12-16 \\
6-26\end{array}$ & $\begin{array}{c}\sim_{18} \\
36-44 \\
\ldots-\end{array}$ & $\begin{array}{l}+0.389 \\
+0.413 \\
+0.543\end{array}$ \\
\hline $\mathrm{HK}-40$ & $\begin{array}{l}750 \\
750 \\
850\end{array}$ & $\begin{array}{l}1,000 \\
3,000 \\
1,000\end{array}$ & $\begin{array}{c}2 \\
2-3 \\
2-7\end{array}$ & $\begin{array}{l}-- \\
-- \\
--\end{array}$ & $\begin{array}{c}8 \\
8 \\
8-10\end{array}$ & $\begin{array}{l}-- \\
--\end{array}$ & $\begin{array}{l}+0.284 \\
-0.069 \\
-0.348\end{array}$ \\
\hline Manaurite $36 \mathrm{XS}$ & $\begin{array}{l}750 \\
750 \\
850\end{array}$ & $\begin{array}{l}1,000 \\
3,000 \\
1,000\end{array}$ & $\begin{array}{c}2 \\
2-3 \\
3-5\end{array}$ & $<\frac{1}{20}$ & $\begin{array}{c}7 \\
6-10 \\
6-7\end{array}$ & $\begin{array}{c}12 \\
10-14 \\
--\end{array}$ & $\begin{array}{l}+0.370 \\
+0.196 \\
-1.192\end{array}$ \\
\hline Manaurite 900 & $\begin{array}{l}750 \\
750 \\
850\end{array}$ & $\begin{array}{l}1,000 \\
3,000 \\
1,000\end{array}$ & $\begin{array}{c}1 \\
2 \\
2-3\end{array}$ & $\begin{array}{l}-- \\
-- \\
--\end{array}$ & $8-10$ & $\begin{array}{c}18 \\
14-28 \\
--\end{array}$ & $\begin{array}{l}+0.362 \\
+0.168 \\
+0.252\end{array}$ \\
\hline Mo-Re 2 & $\begin{array}{l}750 \\
750 \\
850\end{array}$ & $\begin{array}{l}1,000 \\
3,000 \\
1,000\end{array}$ & $\begin{array}{c}1 \\
5-7 \\
4-5\end{array}$ & $\begin{array}{c}1 \\
5-7 \\
10-20\end{array}$ & $\begin{array}{c}5-6 \\
5-7 \\
8-10\end{array}$ & $\begin{array}{c}7-9 \\
15-18 \\
\sim 60\end{array}$ & $\begin{array}{r}0.384 \\
-0.330 \\
0.884\end{array}$ \\
\hline
\end{tabular}




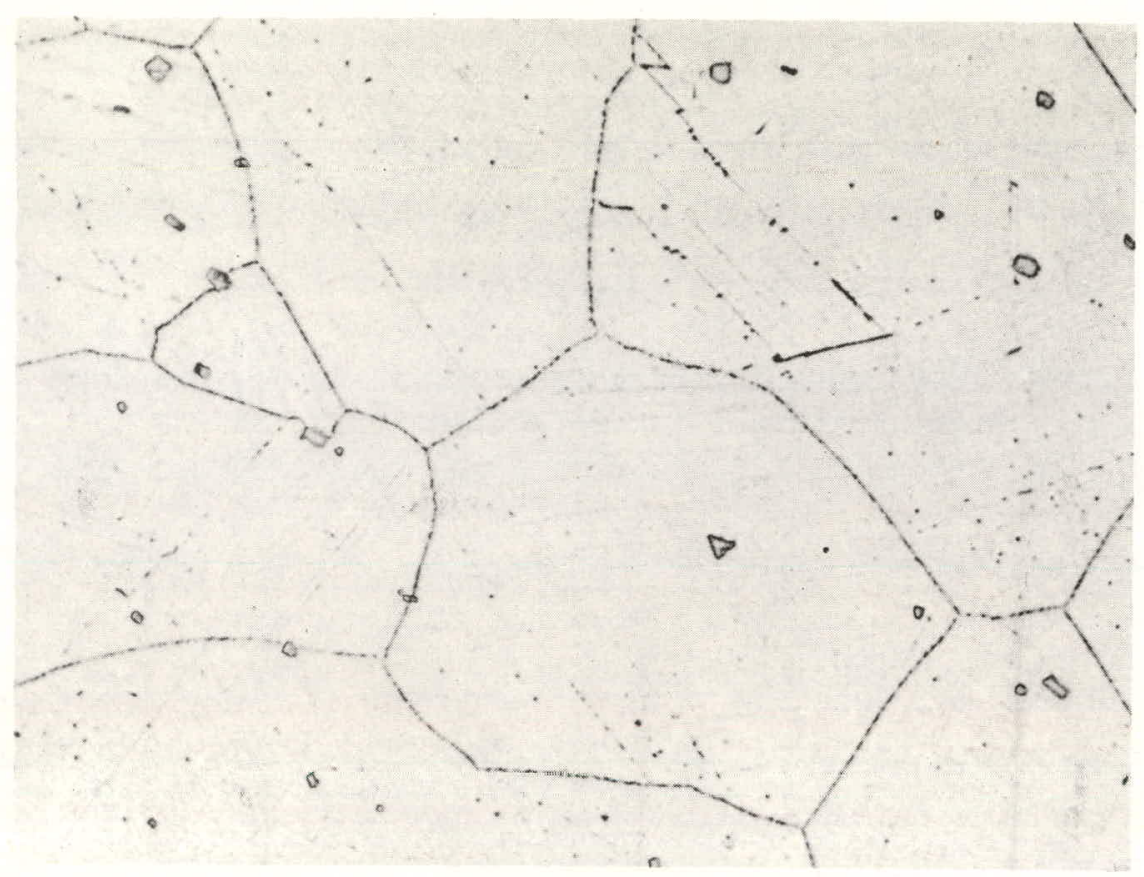

Oxalic Acid

(a) Microstructure shows mixture of coarse heterogeneously dispersed precipitates and fine precipitated carbides dispersed intergranularly on grain boundaries and on twin boundaries. Note fine carbide precipitation along preferred crystallographic directions.

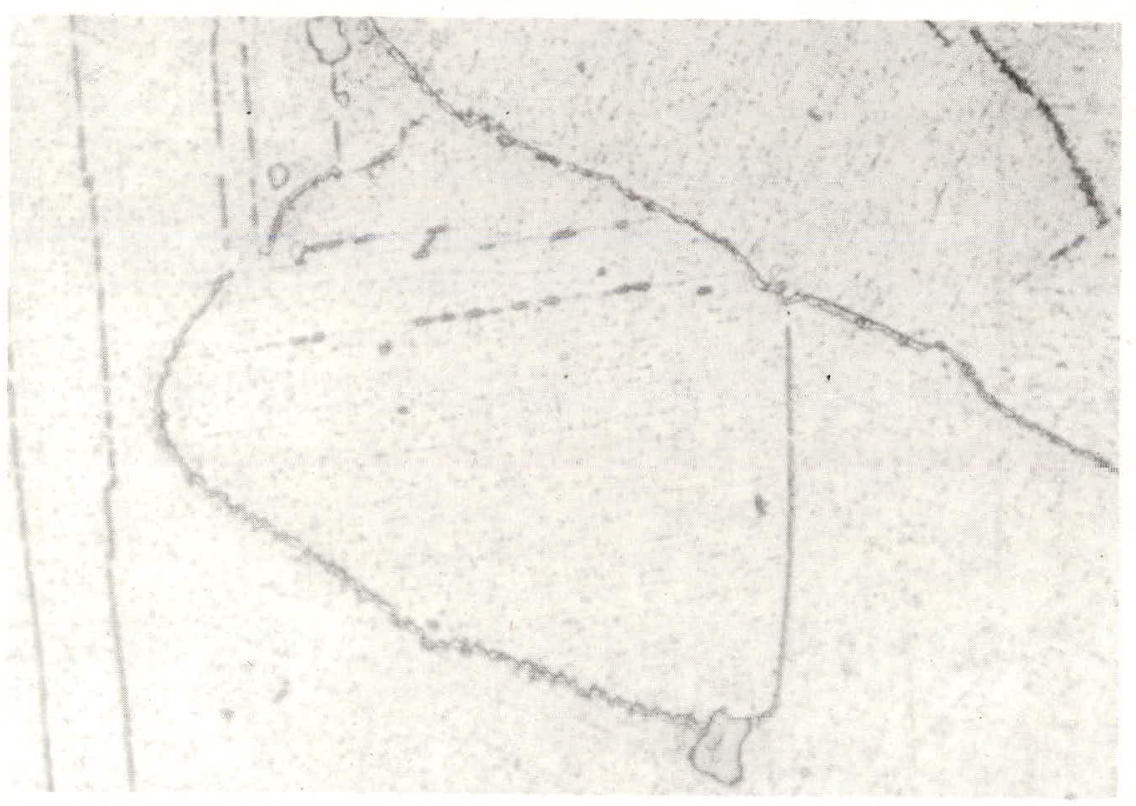

Oxalic Acid

(b) Microstructure shows typical phases present: fine-to-intermediate precipitated carbides (probably $\mathrm{M}_{23} \mathrm{C}_{6}$ ) and coarse roughly cubic or globular precipitates (presumably TiN or TícN).

Figure 10. Optical Photomicrographs Showing Etched Internal Microstructure of Inconel 617 after 3,000 hr Exposure in Controlled Purity Helium at $750^{\circ} \mathrm{C}$. 


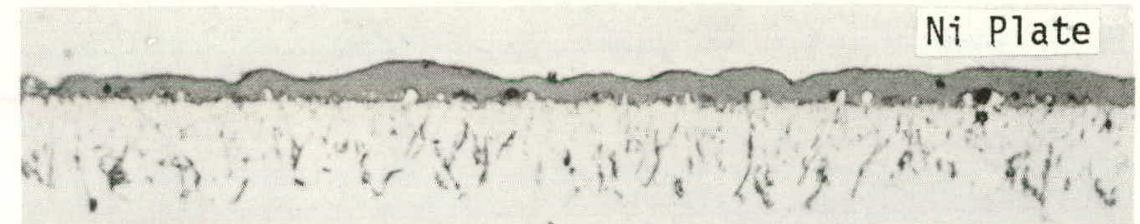

Oxalic Acid

$1000 \mathrm{x}$

(a) Microstructure shows single layered scale containing white particles and region of internal oxidation.

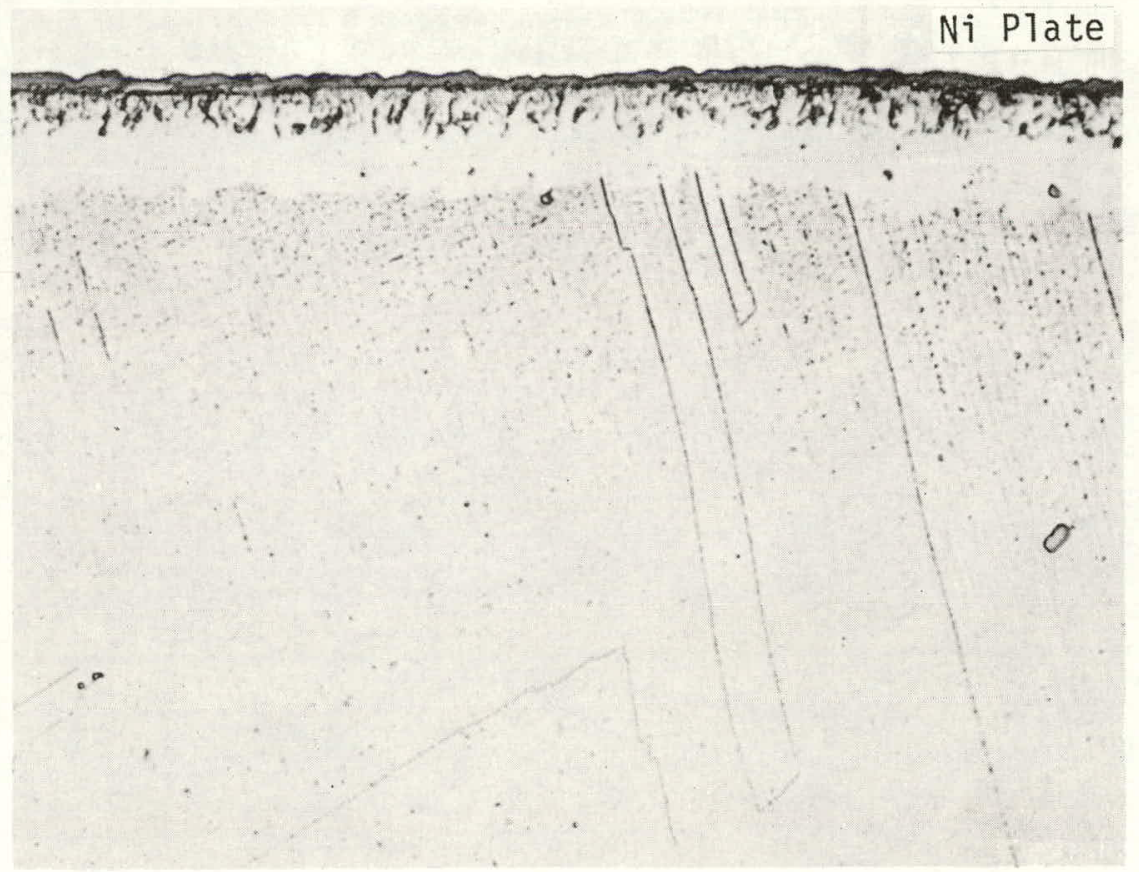

Oxalic Acid

(b) Microstructure shows surface scale, internal oxidation, zone of alloy depletion, and increased carbide precipitation.

Figure 11. Optica1 Photomicrographs Showing Surface Condition (a) Unetched and (b) Etched for Inconel 617 after 3,000 hr Exposure in Controlled Purity Helium at $750^{\circ} \mathrm{C}$. 


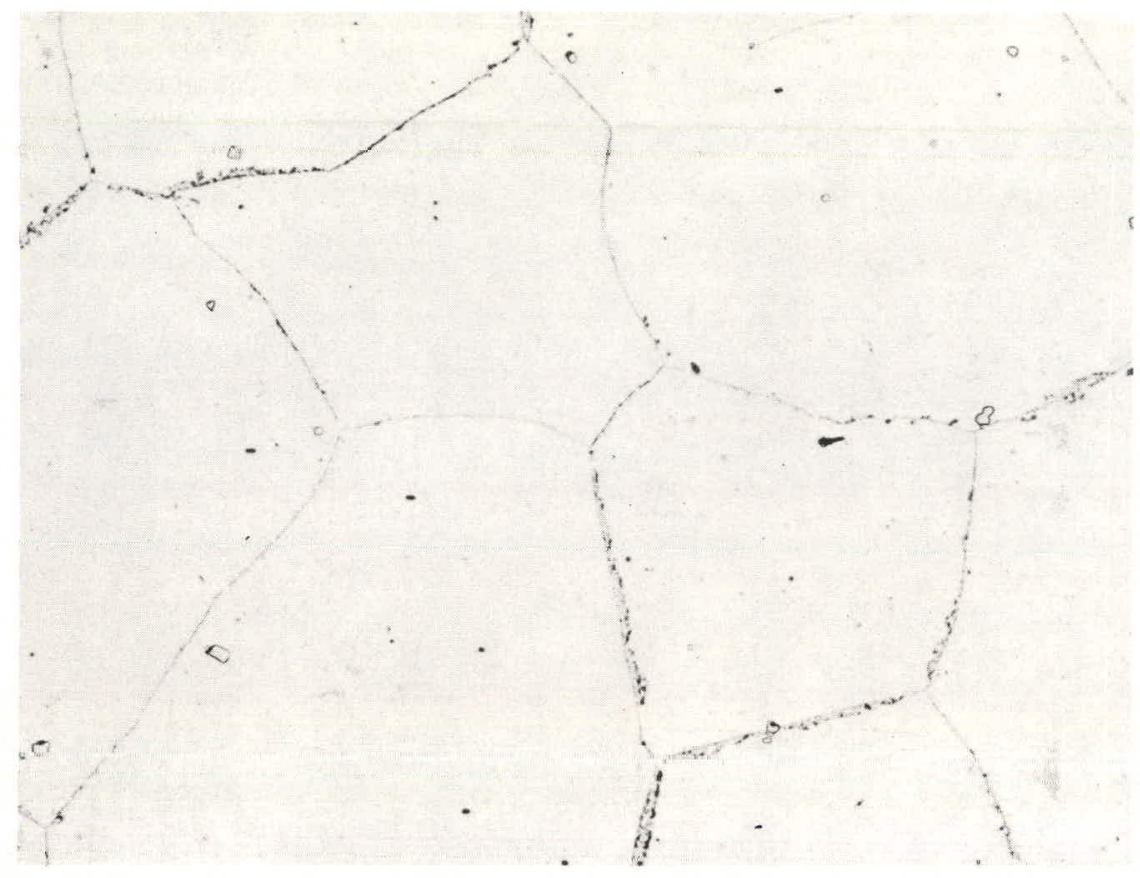

Oxalic Acid

(a) Microstructure shows mixture of coarse heterogeneously dispersed precipitates and fine-to-intermediate precipitated carbides dispersed intra- and intergranularly and on twin boundaries.

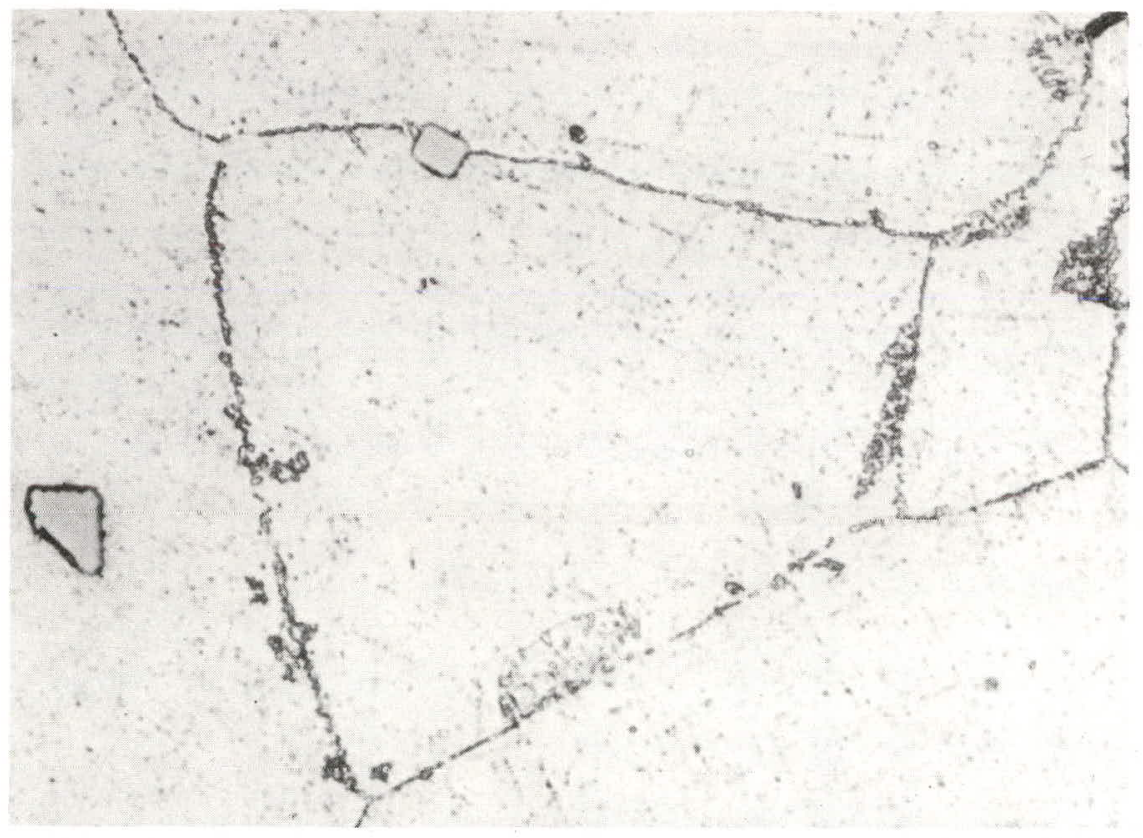

Oxalic Acid

(b) Microstructure shows typical phases present: coarse cubic or angular precipitates, (gray phase, presumably TiN or TiCN) and intermediate-to-fine precipitated carbides (probably $\mathrm{M}_{23} \mathrm{C}_{6}$ ).

Figure 12. Optical Photomicrographs Showing Etched Internal Microstructure of Inconel 618E after 3,000 hr Exposure in Controlled Purity Helium at $750^{\circ} \mathrm{C}$. 


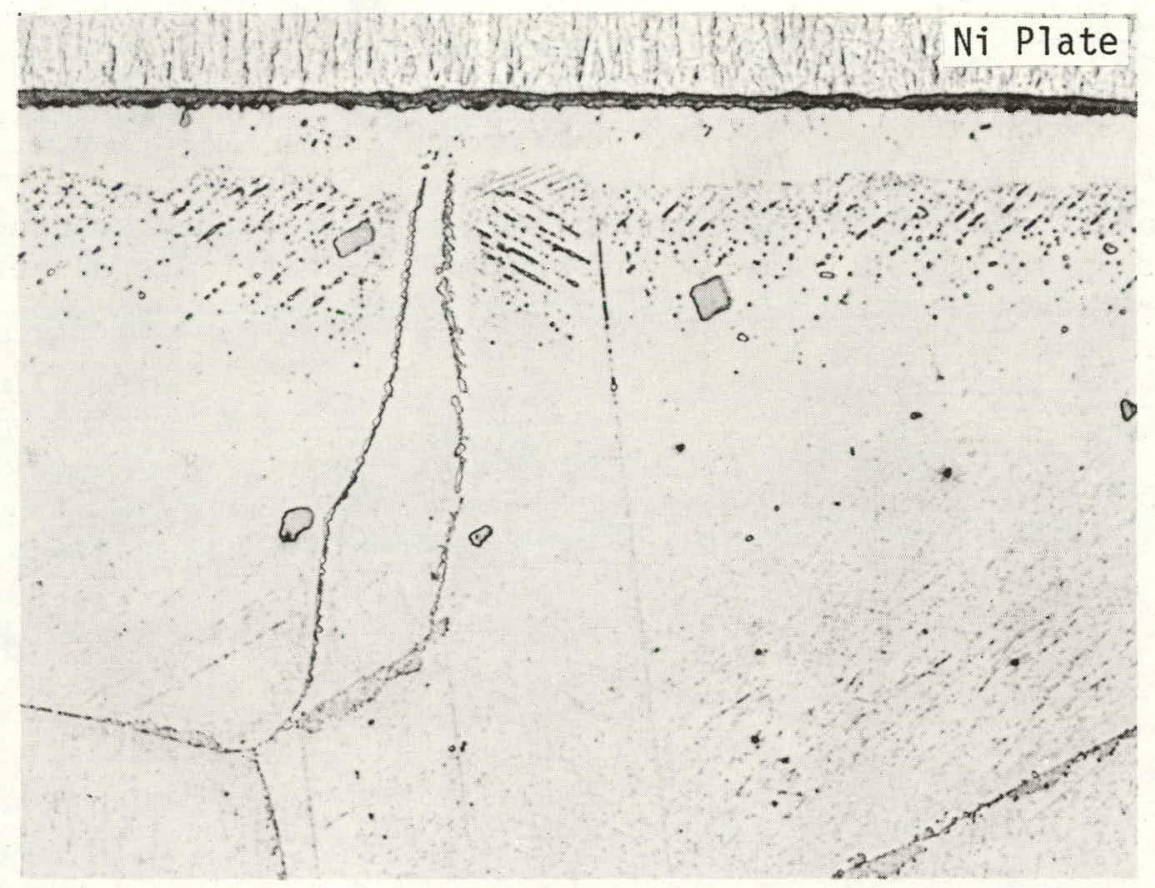

Oxalic Acid

Microstructure shows surface scale, zone of alloy depletion, and increased carbide precipitation.

Figure 13. Optical Photomicrograph Showing Surface Condition and Etched Subsurface Microstructure of Inconel $618 \mathrm{E}$ after 3,000 $\mathrm{hr}$ Exposure in Controlled Purity Helium at $750^{\circ} \mathrm{C}$. 


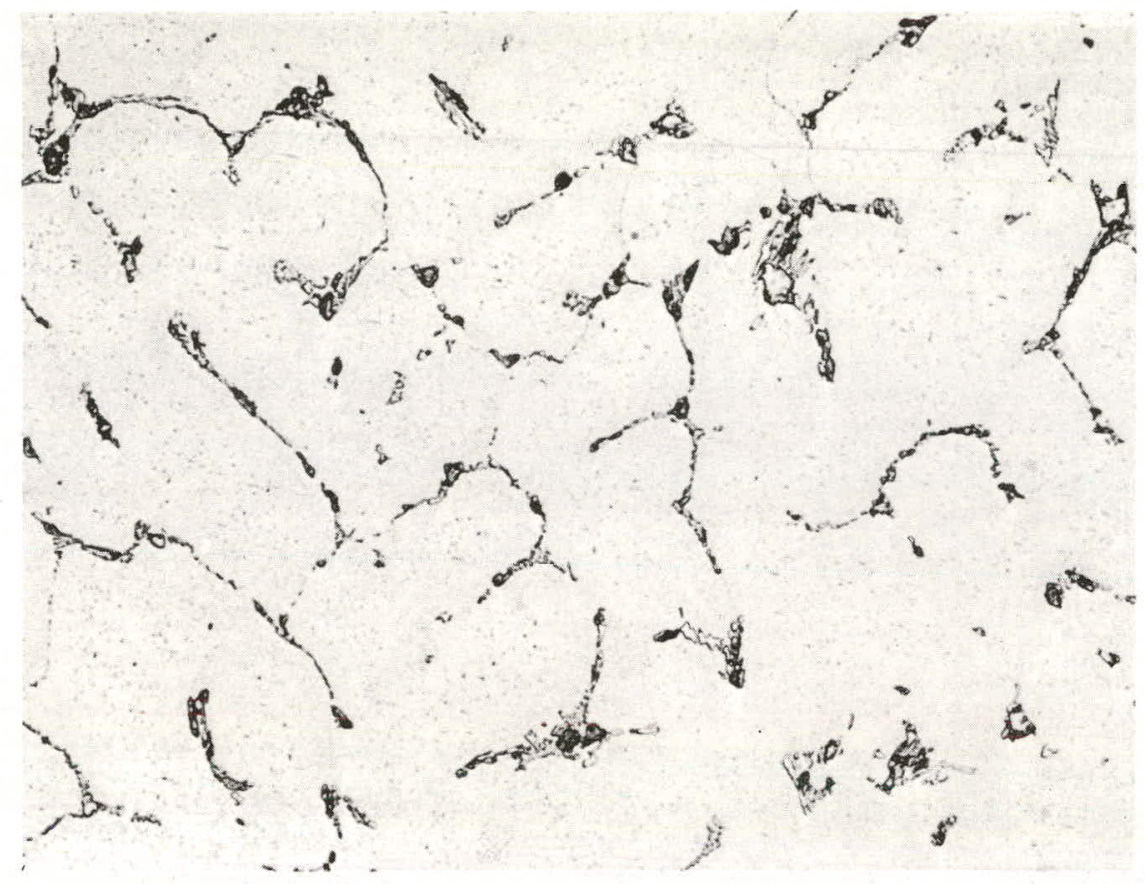

Murakami's Etch

(a) Microstructure shows austenite-carbide eutectic dispersed at dendrite boundaries or interdentritically and precipitated carbides dispersed intradendritically.

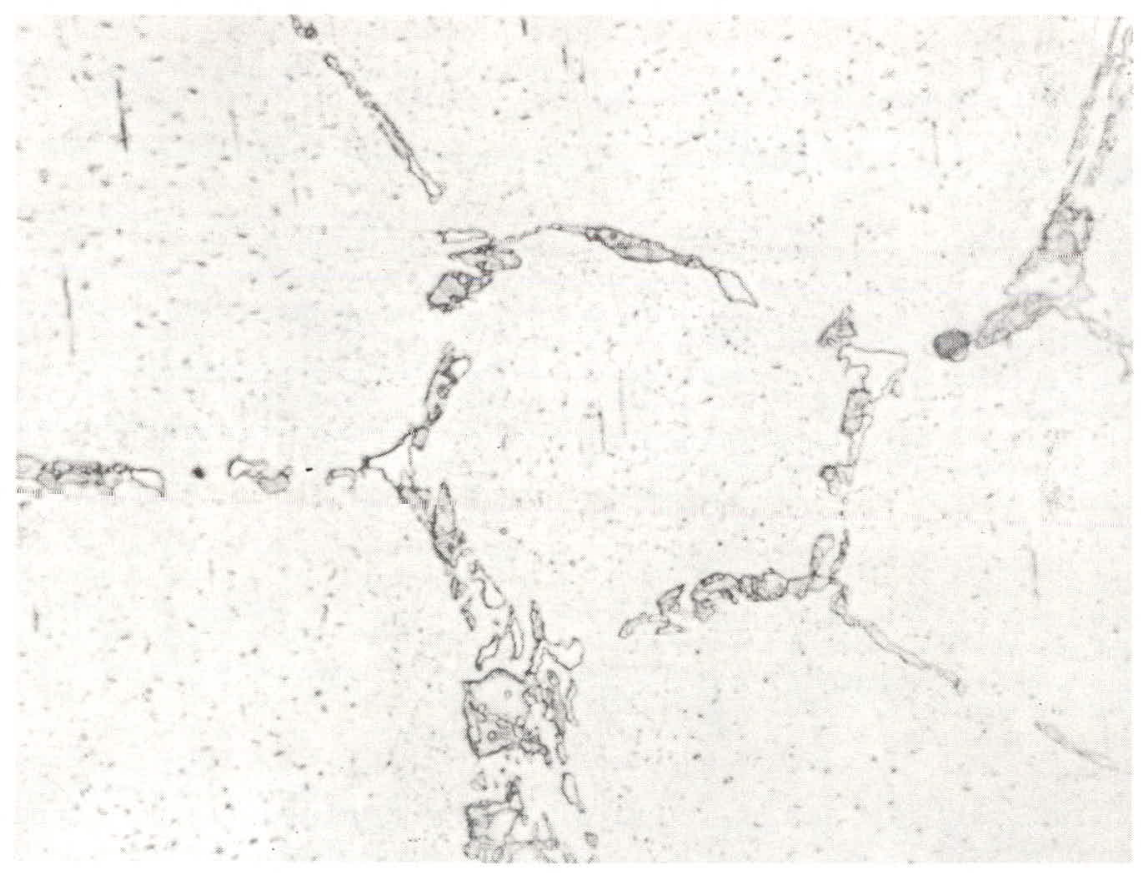

Murakami's Etch

(b) Microstructure shows script-type austentic-carbide eutectic, fine secondary carbides and fine Widmanstatten precipitate.

Figure 14. Optical Photomicrographs Showing Etched Internal Microstructure of HK-40 after 3,000 hr Exposure in Controlled Purity Helium at $750^{\circ} \mathrm{C}$. 


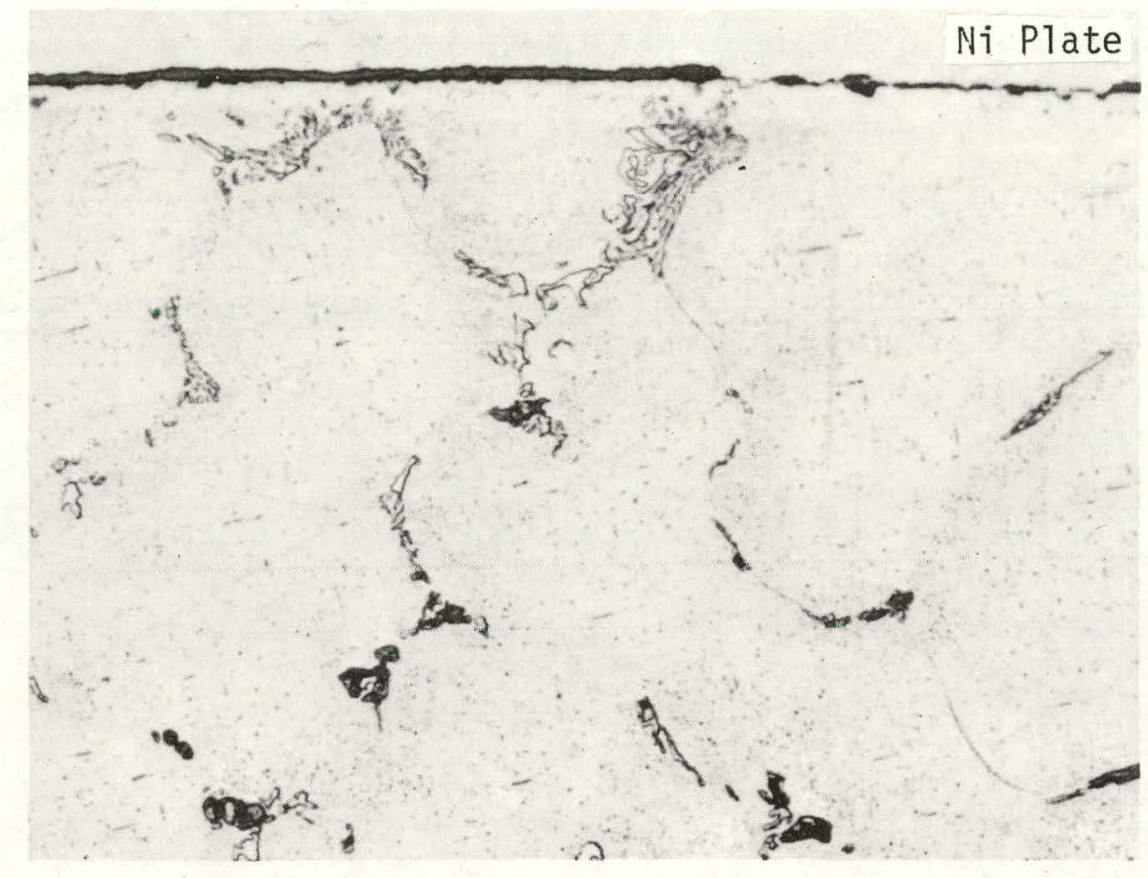

Murakami's Etch

$500 x$

Microstructure shows spalled surface scale and alloy depleted zone.

Figure 15. Optical Photomicrograph Showing Surface Condition and Etched Subsurface Microstructure of HK-40 after 3,000 hr Exposure in Controlled Purity Helium at $750^{\circ} \mathrm{C}$. 


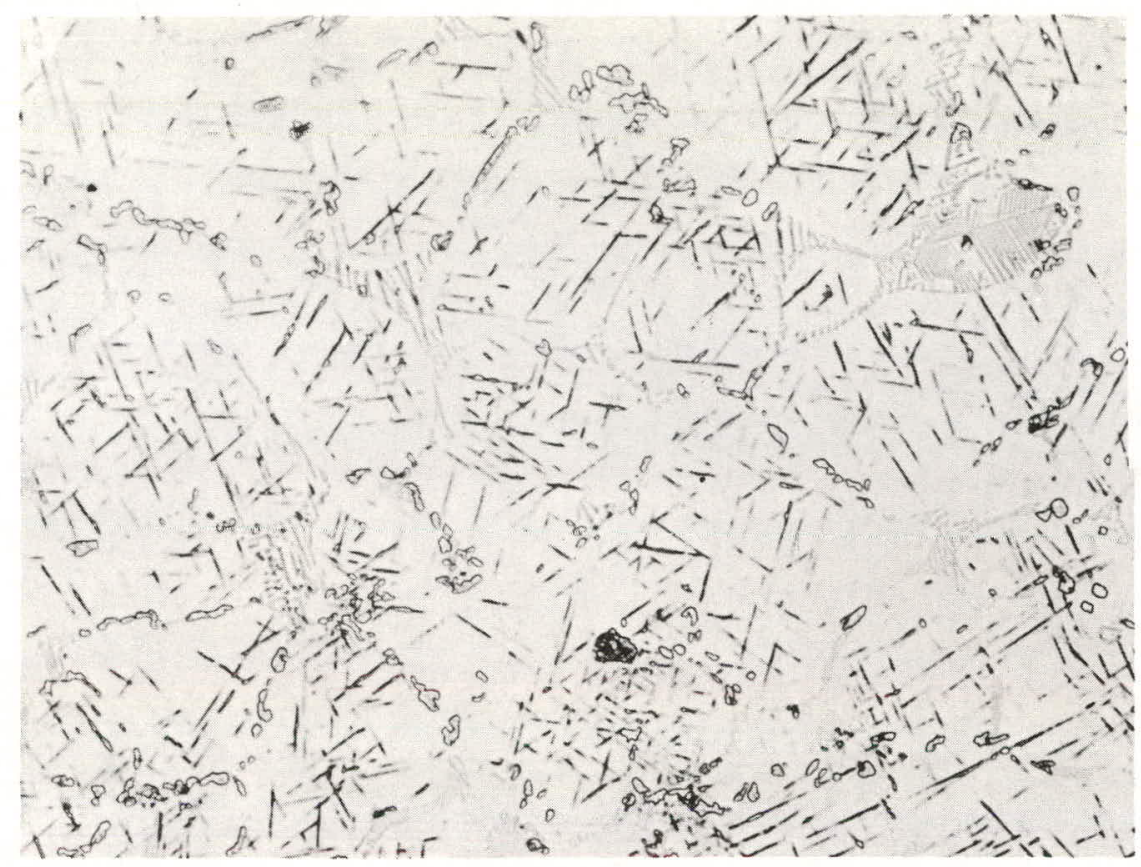

Murakami's Etch

(a) Microstructure shows austenite-carbide eutectic dispersed at dendrite boundaries or interdendritically, precipitated carbides and acicular precipitate typical of the Sigma phase.

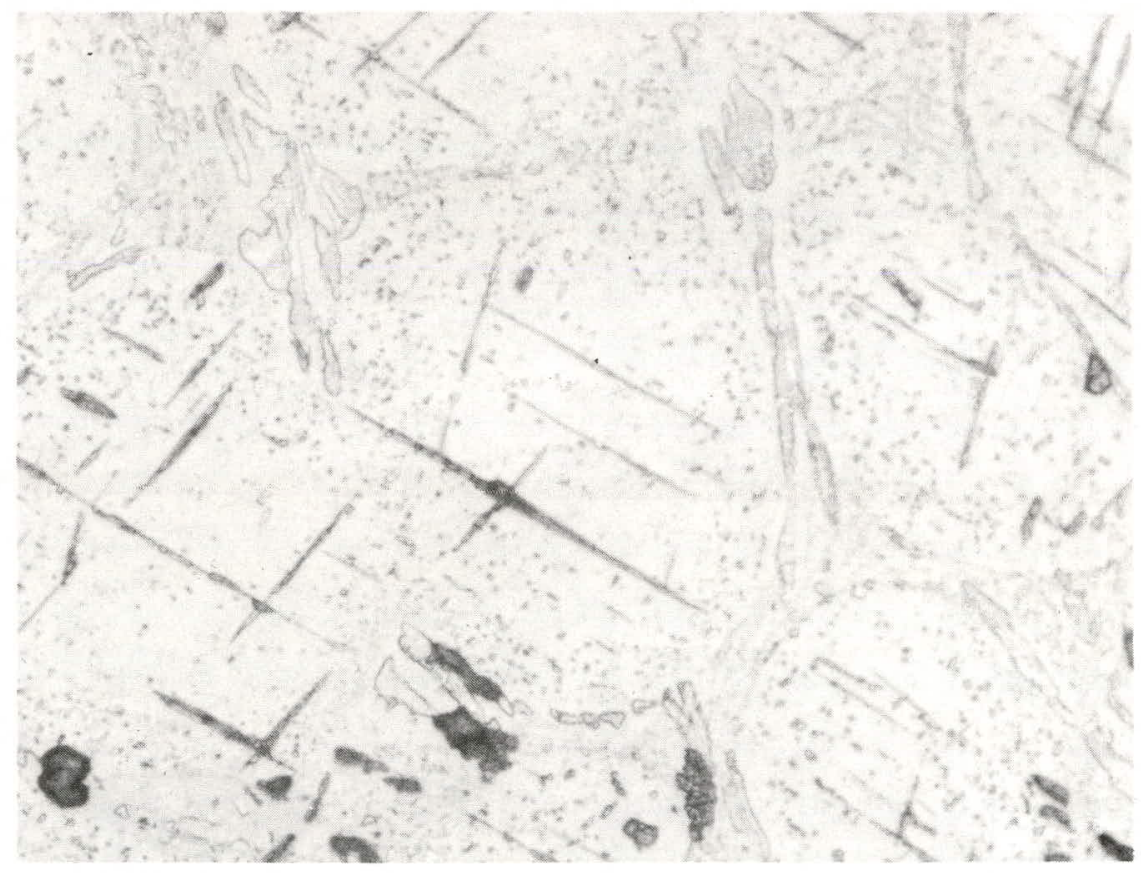

Murakami's Etch

(b) Microstructure shows globular eutectic carbide, fine secondary carbides and acicular precipitate typical of the Sigma phase.

Figure 16. Optical Photomicrographs Showing Etched Internal Microstructure of Manaurite $36 \mathrm{XS}$ after 3,000 hr Exposure in Controlled Purity Helium at $750^{\circ} \mathrm{C}$. 


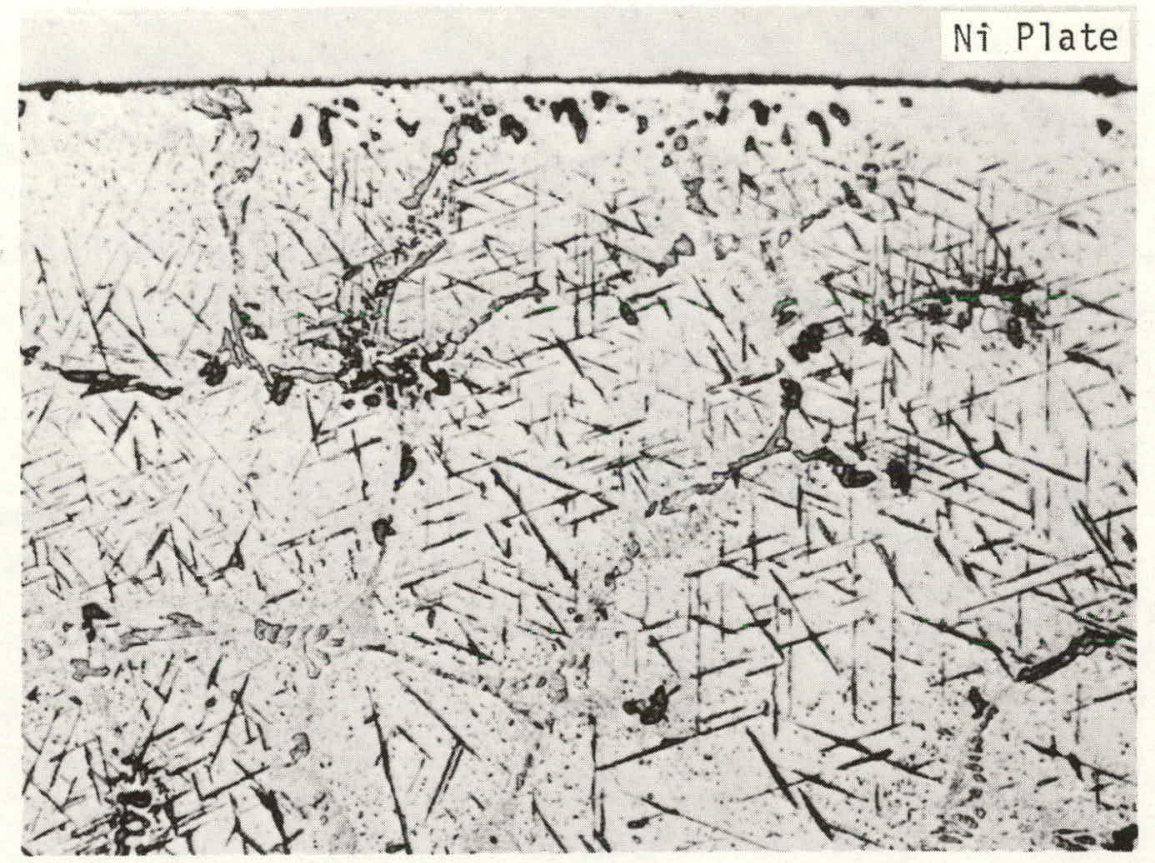

Murakami's Etch

$500 \mathrm{X}$

Microstructure shows surface scale, alloy depleted region, and increased fineto-coarse carbide precipitation in zone near surface.

Figure 17. Optical Photomicrograph Showing Surface Condition and Etched Subsurface Microstructure of Manaurite 36XS after 3,000 hr Exposure in Controlled Purity Helium at $750^{\circ} \mathrm{C}$. 


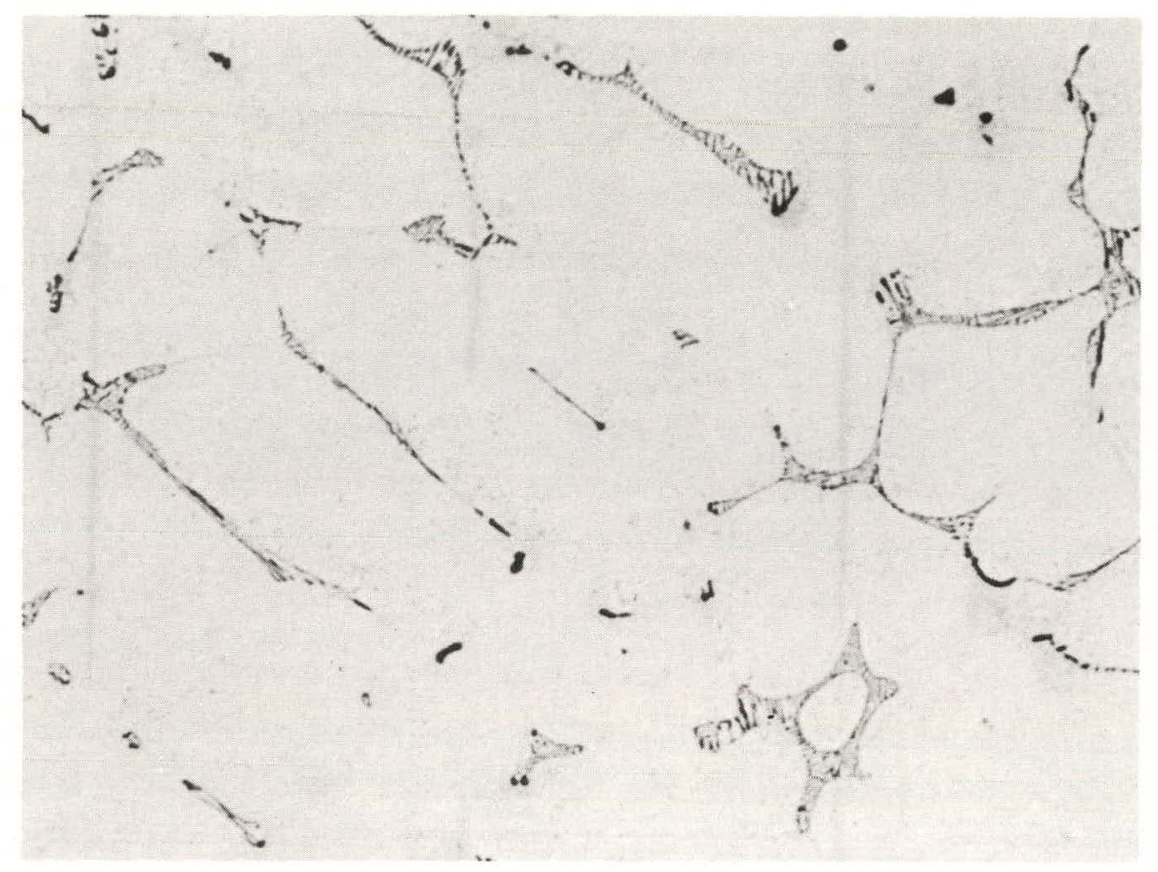

Murakami's Etch

(a) Microstructure shows austentic-carbide eutentic dispersed at dendrite boundaries or interdendritically and precipitated carbides dispersed intradendritically.

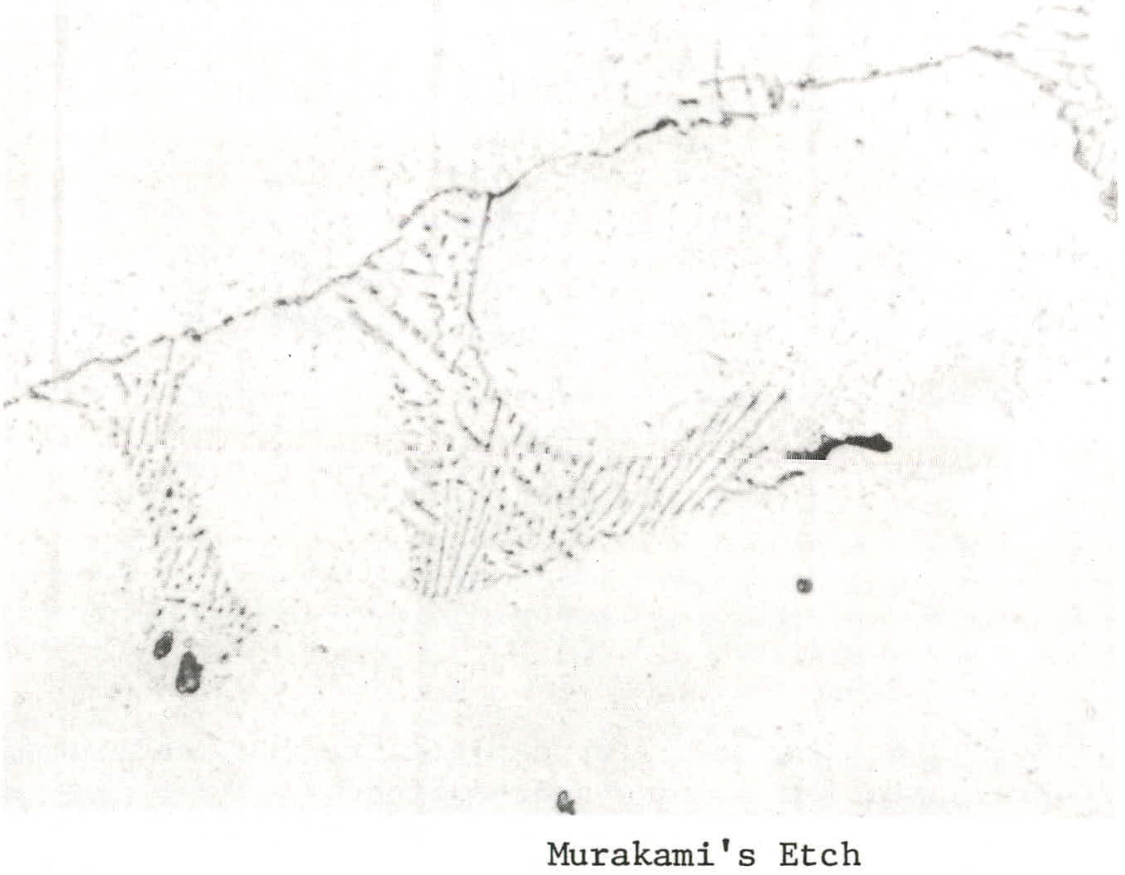

(b) Microstructure shows typical phases present: lace-like austenite-carbide eutectic and fine secondary (precipitated) carbides.

Figure 18. Optical Photomicrographs Showing Etched Internal Microstructure of Manaurite 900 after 3,000 hr Exposure in Controlled Purity Helium at $750^{\circ} \mathrm{C}$. 


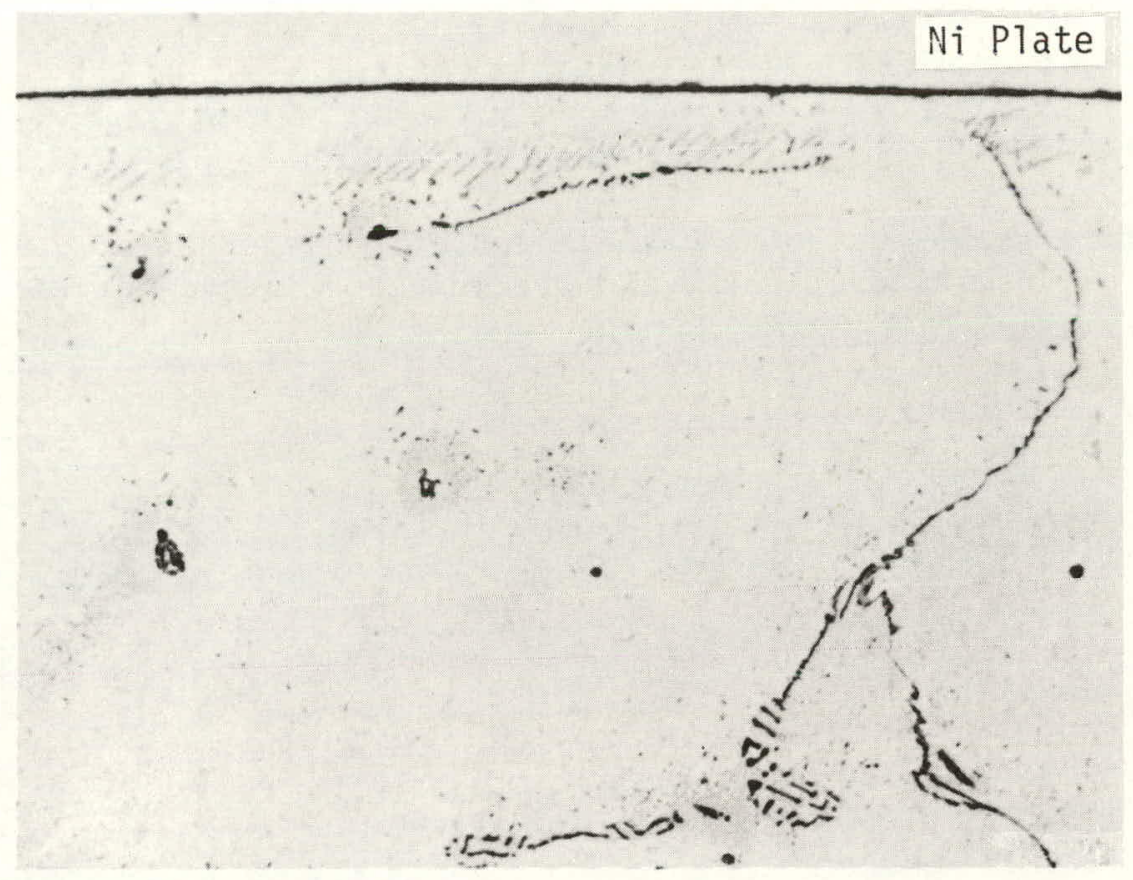

Murakali's Etch

Microstructure shows surface scale, alloy depleted zone, and increased fine-tointermediate carbide precipitation in near surface region.

Figure 19. Optical Photomicrophgraph Showing Surface Condition of Manaurite 900 after 3,000 hr Exposure in Controlled Purity Helium at $750^{\circ} \mathrm{C}$. 


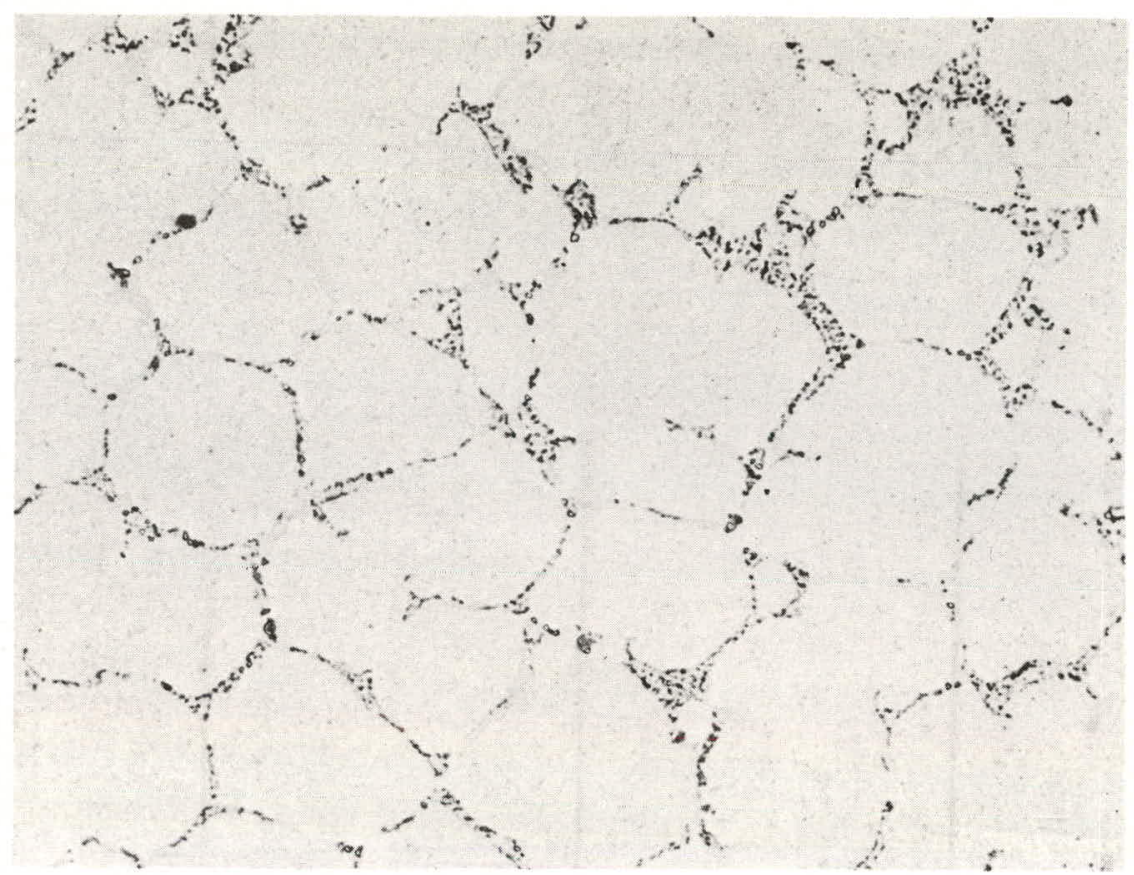

Murakami's Etch

(a) Microstructure shows austenite-carbide eutectic dispersed at dendrite boundaries or interdendritically and precipitated intradendritic carbides.

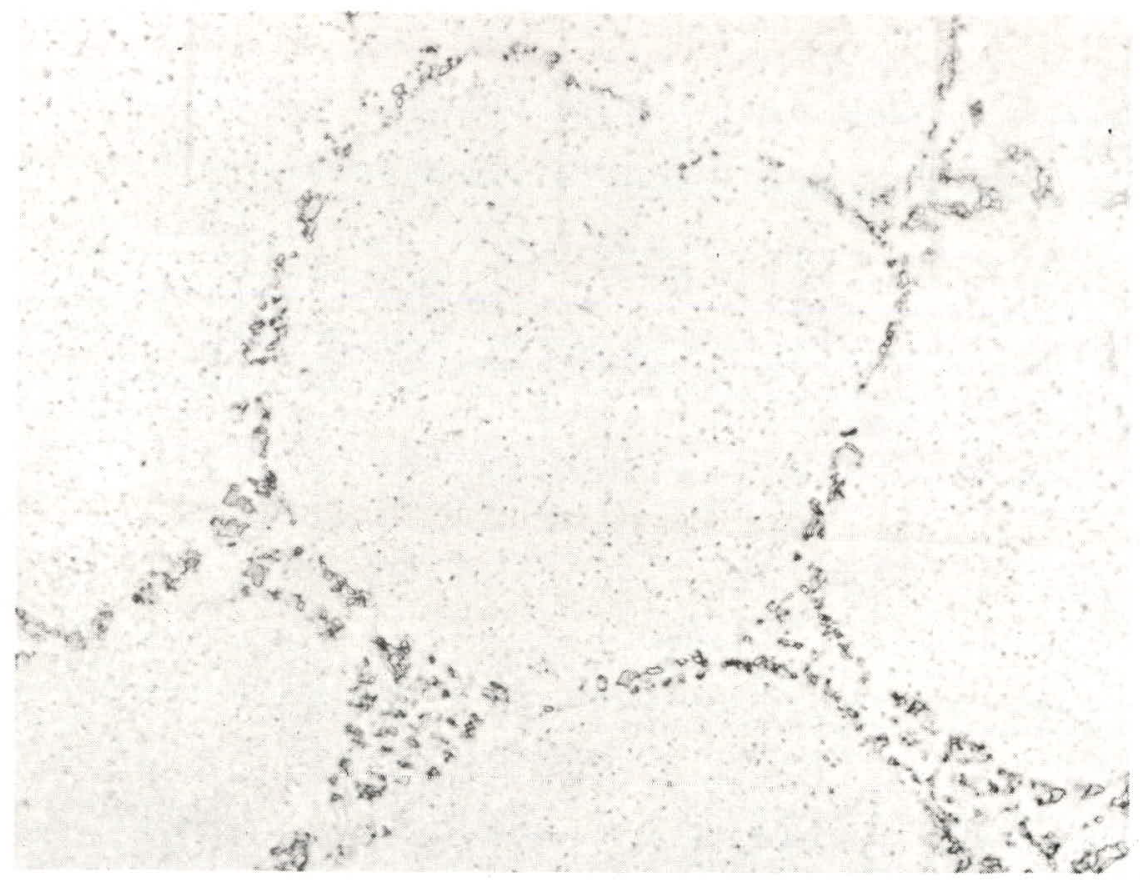

Murakami's Etch

(b) Microstructure shows typical phases present: coarsened globular austenticcarbide eutectic and fine secondary carbides.

Figure 20. Optical Photomicrographs Showing Etched Internal Microstructure of Mo-Re 2 after 3,000 hr Exposure in Controlled Purity Helium at $750^{\circ} \mathrm{C}$. 


\section{Ni Plate}

Unetched

$1000 \mathrm{x}$

(a) Microstructure shows partially spalled or missing triple layered surface scale.

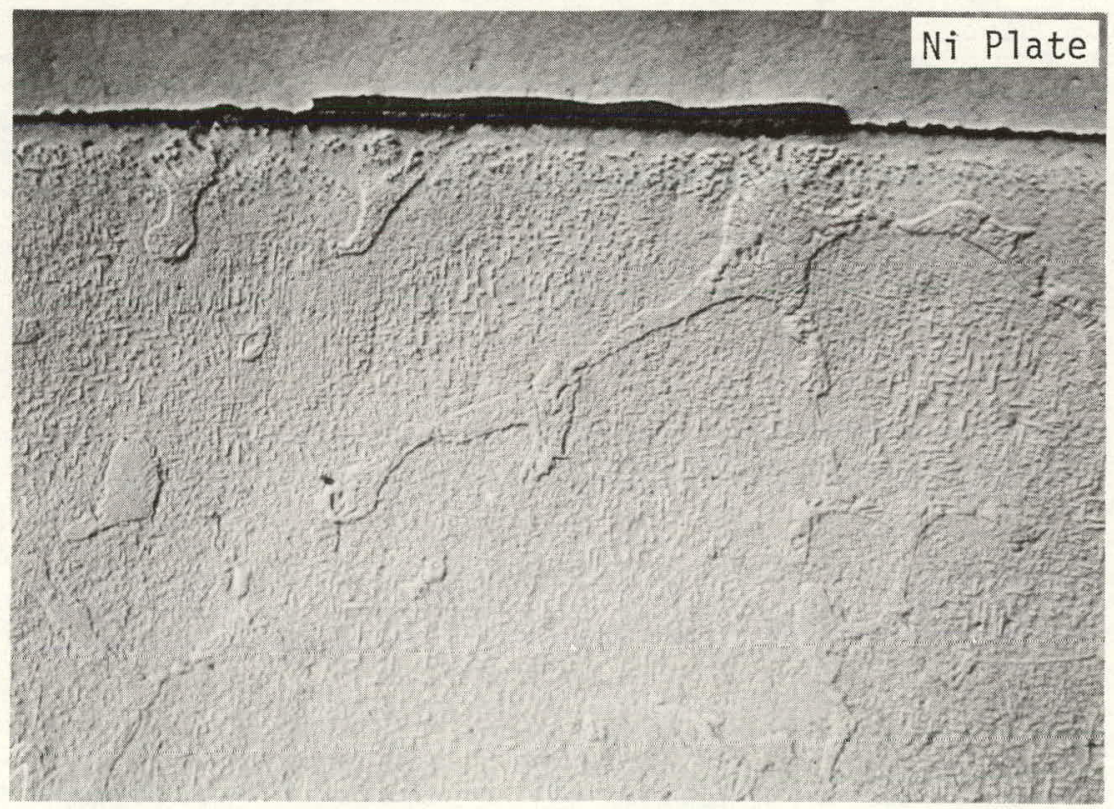

Unetched

$1000 \mathrm{x}$

(Differential Interference Contrast)

(b) Microstructure shows surface scale, zone of alloy depletion, and high density region of carbide precipitation.

Figure 21. Optical Photomicrographs Showing Unetched Surface Condition of Mo-Re 2 after 3,000 hr Exposure in Controlled Purity Helium at $750^{\circ} \mathrm{C}$. 
region was present in each of the six materials examincd, with distinct signs of carburization seen in five of the six alloys studied. Perhaps the lack of increased subsurface carbide precipitation in the $\mathrm{HK}-40$ specimen may be attributable to the inherently high carbon content of the material or may indicate that the incubation period for this phemomena has not been exceeded. At any rate, the premature rupture of an HK-40 screening creep specimen is not encouraging, since thermal effects alone (aside from carburization) may severely limit the usefulness of this alloy.

Although the results are limited, it appears that carburization was more prevalent after $750^{\circ} \mathrm{C} / 3,000$-hour exposure relative to that observed after $1,000-$ hour at $850^{\circ} \mathrm{C}$, suggesting that, at least in this temperature regime, the 2,000-hour exposure increment is the more important variable in terms of carburization. 


\section{REFERENCES}

1. S.N. Rosenwasser and W.R. Johnson, "Gas Turbine and Advanced HTGR Materials Screening Test Program, 10,000 Hour Results and Semi-Annual Progress Report for the Period Ending March 31, 1977," General Atomic Company, GA-A14407, July 1977.

2. Advanced Gas.Cooled Nuclear Reactor Materials Evaluation and Development Program, Progress Report for Period January 1, 1980 - March 31, 1980, C00-2975-43.

3. W.R. Johnson and L.D. Thompson, "Effects of Methane Concentration on The Controlled-Impurity Helium Behavior of Selected HTGR Structural Materials," General Atomic Company, GA-A15565, December 1979. 


\subsection{TASK 9 - DATA MANAGEMENT AND PROGRAM MANAGEMENT}

\section{$\underline{2.7 .1 \text { Data Management }}$}

Work on encoding of the Planning and Management - Materials Evaluation and Development (PAMMED) forms continued during the quarter. The following forms were completed for all the NPH Alloys: Chemical Analysis, Material Description, Creep Rupture, Impact, Varestraint Weld, Process Description, Tensile and Specimen Description.

\subsubsection{Program Management}

The following program meetings or related meetings were attended or conducted by program staff during the report period.

- An HTGR materials program coordination meeting was held at Oak Ridge, Tennessee on May 14, 15, 1980. The meeting was attended by program participants representing General Atomic Company (GAC), Oak Ridge Nationa1 Laboratory (ORNL), Gas Cooled Reactor Associates (GCRA) and General Electric Co. (GE).

- General Electric personnel attended a meeting at the General Atomic Company on June 3, with materials engineers from GAC, ORNL and GCRA. The purpose of the meeting was to estimate materials evaluation and development costs for each of the four lead plant options belng assessed for the U.S. HTGR Program.

- Weekly meetings were held with the General Electric program personnel in Schenectady, N.Y. to review technical results and program status. The program master schedule is presented in Figure 22. 


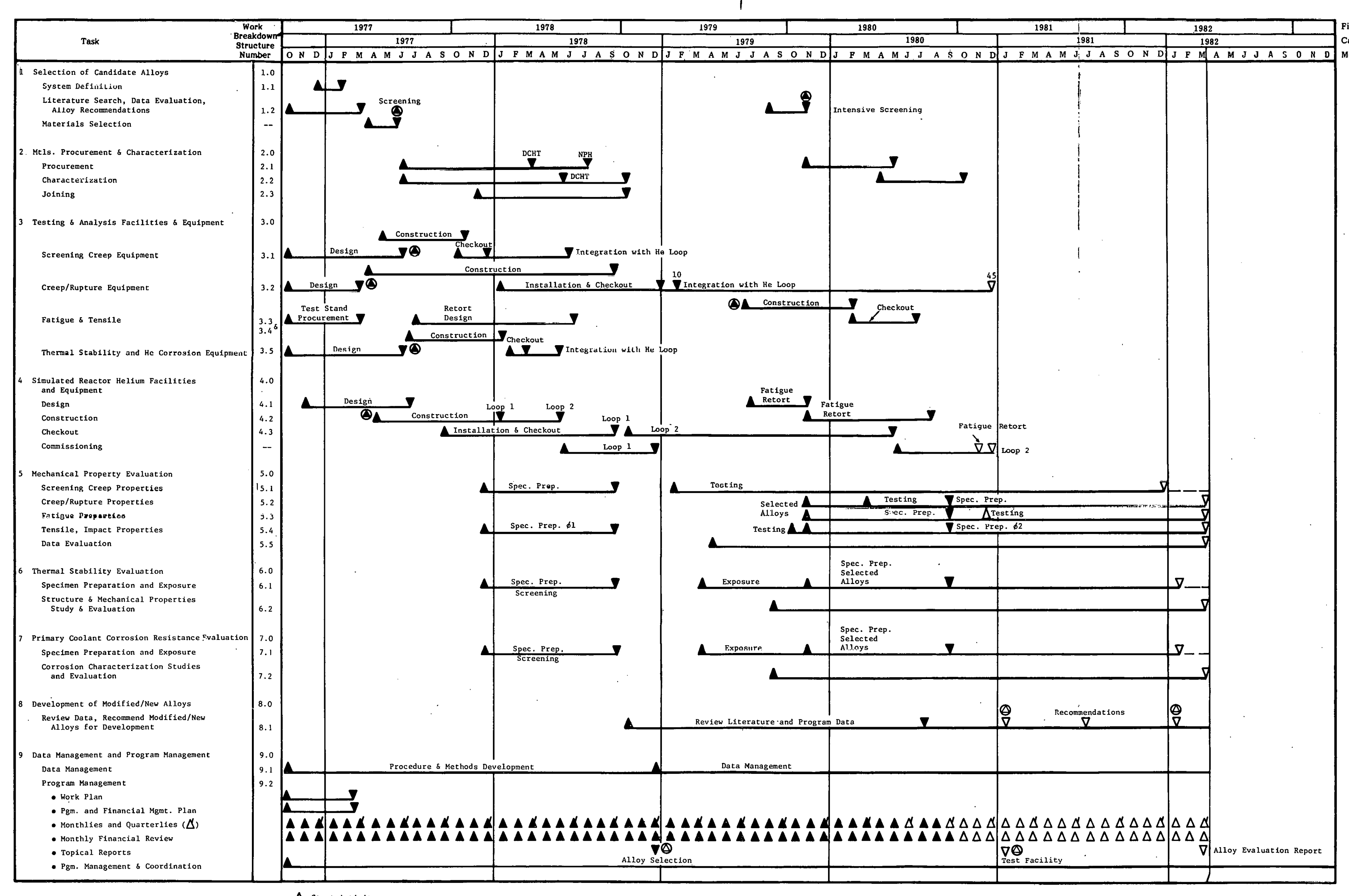


Section 3.0

WORK TO BE COMPLETED DURING THE NEXT QUARTER 
- The multispecimen creep tests at $750^{\circ} \mathrm{C}$ and $850^{\circ} \mathrm{C}$ will reach 5,000 hours on test and the fifth 1,000-hour interval creep strain measurements will. be completed on these specimens."

- The multispecimer creep tests at $950^{\circ} \mathrm{C}$ and $1050^{\circ} \mathrm{C}$ will reach 1,000 hours on test and the first 1,000-hour interval creep strain measurements will be completed on these specimens.

- The intensive screening single specimen creep rupture tests will continue.

- The intensive screening phase air creep rupture tests will continue.

- The room temperature tensile tests of specimens exposed in controlled purity helium for 1,000 hours at $950^{\circ} \mathrm{C}$ will be completed.

- Bend tests of as-welded NPH alloys for the intensive screening phase will be completed.

- Evaluation of corrosion pins and weldments exposed for 1,000 and 3,000 hours at $950^{\circ} \mathrm{C}$ in controlled purity helium will continue. 